\title{
DR. 943
}

DOE/JPL/954882-15

PROCESS DEVELOPMENT FOR AUTOMATED SOLAR CELL AND MODULE PRODUCTION

Task 4: Automated Array Assembly

Annual Report

By

C. R. Witham

June 12, 1979

\section{MASTER}

Work Performed Under Contract No. NAS-7-100-954882

MBAssociates

San Ramon, California

and

ARCO Solar, Inc.

Chatsworth, California

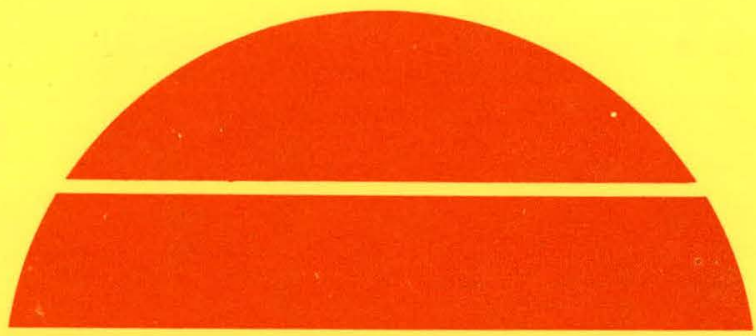

\section{U.S. Department of Energy}

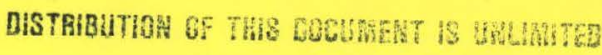




\section{DISCLAIMER}

This report was prepared as an account of work sponsored by an agency of the United States Government. Neither the United States Government nor any agency Thereof, nor any of their employees, makes any warranty, express or implied, or assumes any legal liability or responsibility for the accuracy, completeness, or usefulness of any information, apparatus, product, or process disclosed, or represents that its use would not infringe privately owned rights. Reference herein to any specific commercial product, process, or service by trade name, trademark, manufacturer, or otherwise does not necessarily constitute or imply its endorsement, recommendation, or favoring by the United States Government or any agency thereof. The views and opinions of authors expressed herein do not necessarily state or reflect those of the United States Government or any agency thereof. 


\section{DISCLAIMER}

Portions of this document may be illegible in electronic image products. Images are produced from the best available original document. 


\section{NOTICE}

This 1epuil was prepared as an account of work sponsored by the United States Government. Neither the United States nor the United States Department of Energy, nor any of their emplnyees, nor any of their contractors, subcontractors, or thuir umployec3, makes any warranty, express or implied, or assumes any legal liability or responsibility for the accuracy, completeness or usefulness of any information, apparatus, product or process disclosed, or represents that its use would not infringe privately owned rights.

This report has been printed directly from copy supplied by the originating organization. Although the copy supplied may not in part or wholc mect the standards for acceptable reproducible copy, it has been used for reproduction to expedite distribution and availability of the information being reported.

Available from the National Technical Information Service, U. S. Department of Commerce, Springfield, Virginia 22161.

Price: Paper Copy $\$ 0.00$

Mierofiche $\$ 3.00$ 


\title{
PROCESS DEVELOPMENT FOR AUTOMATED SOLAR CELL AND MODULE PRODUCTION
}

\section{TASK 4: AUTOMATED ARRAY ASSEMBLY}

\author{
Annual Report
}

PREPARED BY: C. R. WTTHAM

12 June 1979

JPL Contract No. 954882

Prepared For:

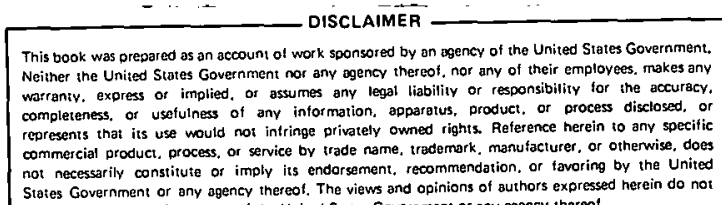

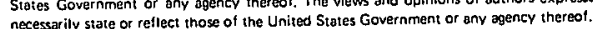

Jet Propulsion Laboratory

4800 Oak Grove Drive

Pasadena, California 91103

The JPL Low-Cost Silicon Solar Array Project is sponsored by the U. S. Department of Energy and forms a part of the Solar Photovoltaic Conversion Program to initiate a major effort toward the development of low-cost solar arrays. This work was performed for the Jet Propulsion Laboratory, California Institute of Technology by agreement between NASA and DoE.

PREPARED BY

\section{MBA MBAssociates}

Bollinger Canyon Road, San Ramon, California 94583

ARCO Solar, Inc. Chatsworth, California 


\section{ABSTRACT}

MBA has been working on the automated array assembly task of the Low-Cost Solar Array project. A baseline sequence for the manufacture of solar cell modules is specified. Starting with silicon wafers, the process goes through damage etching, texture etching, junction formation, plasma edge etch, aluminum back surface field formation, and screen printed metallization to produce finished solar cells which are then series connected on a ribbon and bonded into a finished ylass, PVB, cedlar module.

A number of steps required additional developmental effort to verify technical and economic feasibility. These steps Include texture etching, plasma edge etch, aluminum back surface field formation, array layup and interconnect, and module edge sealing and framing. 
TABLE OF CONTENTS

Section

Title

Page

1.0

INTRODUCTION

2.0

BASELINE PROCESS SEQUENCE DESCRIPTION AND CRITICAL REVIEW

2.1

Process Step Descriptions

2.1 .1

Incoming Inspection

2.1 .1 .1

Description

2.1 .1 .2

Input Requirements/Characteristics

2.1 .1 .3

Output Requirements/Characteristics

2.1 .1 .4

Materials and Supplies Used

2.1 .1 .5

Equipment Used

2.1 .1 .6

2.1 .2

2.1 .2 .1

2.1.2.2

2.1 .2 .3

2.1 .2 .4

2.1 .2 .5

Critical Review

Etch, Clean and Dry

Description

Input Requirements/Characteristics

Output Requirements/Characteristics

Materials and Supplies Used

Equipment Used

Critical Review

Diffusion

2.1 .3

2.1 .3 .1

2.1 .3 .2

$2.1 \cdot 3.3$

2.1 .3 .4

2.1 .3 .5

2.1 .3 .6

2.1 .4

2.1 .4 .1

2.1 .4 .2

2.1 .4 .3

2.1 .4 .4

2.1 .4 .5

2.1 .4 .6

2.1 .5

2.1.5.1

2.1 .5 .2

2.1 .5 .3

2.1 .5 .4

2.1 .5 .5

2.1 .5 .6

2.1 .6

2.1 .6 .1

2.1 .6 .2

$2.1 \cdot 6.3$

Description

Input Requirements/Characteristics

Output Requirements/Characteristics

Materials and Supplies Used

Equipment Used

Critical Review

Edge Etch

Description

Input Requirements/Characteristics

Output Requirements/Characteristics

Materials and Supplies Used

Equipment Used

Critical Review

Back Contacting

Description

Input Requirements/Characteristics

Materials and Supplies Used 16

$\begin{array}{ll}\text { Equipment Used } & 16\end{array}$

Critical Review 17

$\begin{array}{ll}\text { Front Contarting } & 17\end{array}$

$\begin{array}{ll}\text { Description } & 17\end{array}$

Input Requirements/Characteristics $\quad 17$

Output Requirements/Characteristics 18

$2.1 \cdot 6.4$

Materials and Supplies Used

18 
TABLE OF CONTENTS (Continued)

$2.1 \cdot 6.5$

Critical Review

18

2.1 .7

Test and Sort

2.1 .7 .1

Description

18

2.1 .7 .2

Input Requirements/Characteristics

18

2.1 .7 .3

Output Requirements/Characteristics

19.

2.1 .7 .4

2.1 .7 .5

2.1 .7 .6

2.1 .8

Materials and Supplies Used

19

Equipment Used

Critical Review

19

Circult Fab

2.1 .8 .1

2.1 .8 .2

2.1 .8 .3

2.1 .8 .4

2.1 .8 .5

2.1 .8 .6

2.1 .9

2.1 .9 .1

2.1 .9 .2

2.1 .9 .3

2.1 .9 .4

2.1 .9 .5

Description

Input Requirements/Characteristics

Output Requirements/Characteristics

Materials and Supplies Used

Equipment Used

Critical Review

20

20

20

20

Pottant Application $\quad 23$

Description $\quad 23$

Input Requirements/Characteristics 23

Output Requirements/Characteristics $\quad 23$

Materials and Supplies Used 23

Equipment Used $\quad 23$

Critical Review $\quad 26$

2.1 .9 .6

2.1 .10

Panel Layup, Wiring and Testing

26

2.1 .10 .1

Description

26

Input Requirements/Characteristics 30

2.1 .10 .3

Output Requirements/Characteristics

30

2.1 .10 .4

Materials and Supplies Used

30

2.1 .10 .5

Equipment Used

30

2.1 .10 .6

Critical Review

30

2.1 .11

Encapsulation

31

Description

31

2.1 .11 .2

Input Requirements/Characteristics

32

Output Requirements/Characteristics 32

2.1 .11 .3

2.1 .11 .4

2.1 .11 .5

2.1 .11 .6

Materials and Supplies Used

32

Equipment Used

33

Critical Review

33

Trimming and Edge Sealing

2.1 .12 .1

Description

2.1 .12 .2

2.1 .12 .3

Input Requirements/Characteristics

34

Output Requirements/Characteristics

34

2.1 .12 .4

2.1 .12 .5

2.1 .12 .6

2.1 .13

Materials and Supplies Used

Equipment Used

Critical Review

34

34

Edge Sealing and Framing

34

2.1 .13 .1

Description

34

34 
TABLE OF CONTENTS (Continued)

Section

Title

$\underline{\text { Page }}$

2.1.13.2 Input Requirements/Characteristics 35

2.1.13.3 Output Requirements/Characteristics 35

2.1.13.4 Materials and Supplies Used 35

2.1 .13 .5 Equipment Used 3.5

2.1.13.6 Critical Review 38

2.1 .14 Final Test 38

2.1.14.1 Description . 38

2.1.14.2 Input Requirements/Characteristics 38

2.1.14.3 Output Requirements/Characteristics 38

2.1.14.4 Materials and Supplies Used 38

2.1.14.5 Equipment Used 38

2.1.14.6 Critical Review 38

2.1.15 Packing and Shipping . 39

2.1 .15 .1 Description 39

2.1.15.2 Input Requirements/Characteristics 39

2.1.15.3 Output Requirements/Characteristics 39

2.1.15.4 Materials and Supplies Used 39

2.1.15.5 Equipment Used 39

2.1 .15 .6 Critical Review . 39

3.0 ECONOMIC ANALYSIS OF BASELINE PROCESS SEQUENCE 40

$4.0 \quad$ VERIFICATION STUDIES

$4.1 \quad$ Etch and Clean 41

4.1.1 Damage and Texture Etch 41

4.1.2 Pre-Diffusion.Cleaning 42

4.2 Edge Etch. 44

4.3 Aluminum Back Contacts and Back Surface Field Formation 45

4.3.1 Background 45

4.3.2 Prior Techniques Utilized in Formation of

4.3.3 Mass Production Techiology 48

4.4 Array Layup and Cell Interconnect 51

4.5 Edge Sealing and Framing 54

4.5.1 Edge Sealants 54

4.5.2 Testing 55

4.5.3 Application and Framing 59

$5.0 \quad$ CONCLUSIONS AND RECOMMENDATIONS 61

$6.0 \quad$ NEW TECHNOLOGY 62

APPENDIX A

APPENDIX B

APPENDIX $C$

APPENDIX D

APPENDIX E 


\section{LIST OF ILLUSTRATIONS}

Figure No.

Title

Page

2-1

Proposed Automated Solar Cell Fabrication

2-2

$2-3$

$2-4$

$2-5$

$2-6$

4-1

4-2

4-3

$$
\text { Process }
$$

Ribbon Fabrication Machine

Ribbon Fabrication Method

Panel Layup Machine

Module Edge Sealing Station

Module Framing Operation

Reflectance From Texturized Surface of 1-0-0 Silicon

Al Paste P+ Back Surface Vis. Control

$\mathrm{V}_{\mathrm{oc}}$ Loss as a Function of Annular Margin

\section{LIET OF TABLES}

Table No.

Title

Page

4-1

4-2

Edge Sealants

56

Sealants Tested

58 


\subsection{INTRODUCTION}

The scope of work under this contract involves specifying a process sequence which can be used in conjunction with automated equipment for the mass production of solar cell modules for terrestrial use. This process sequence is then critically analyzed from a technical and economic standpoint to determine the technological readiness of each process step for implementation. The process steps are ranked according to the degree of development effort required and according to their significance to the overall process. Those steps requiring the most development are to be worked with to demonstrate their feasibility to be used in such an automated process. Under this contract the steps receiving verification effort are: back contact netallization, automated cell array layup/interconnect, and module edge sealing.

This. work has been done to improve the performance of solar modules and to lower the cost through process development and large scale automation. The guldelines used in this effort has been to work toward a process sequence which w1ll provide a 500 megawatt/year production capacity in the industry by the year 1986 . The baseline factory design used within this industry has a capacity for 200 megawatt/year production. The price goal guiding the effort has been to provide photovoltalc power at $\$ .50 /$ watt in a 1986 time frame. These photovoltaic cells must be encapsulated for protection against the envirunment and therefore allow an uperaling life of 20 years.

The majority of the efforts under this contract have been directed at the area receiving verification studies as listed above.

Contact metallization is an area of current (and future) cell production which represents a large percentage of the added cost to a wafer during cell making. Metallization also represents an area which can have an effect upon the useful life of an array through contact corrosion characteristics. 
The efforts of ARCO Solar Inc. (ASI) under subcontract to this work have largely been directed at using thick film aluminum in a back contact metallization scheme to improve cell performance through back surface field formation, and reduce materials costs. Work was directed at performing this aluminum p+ metallization in an automated fashion using a belt furnace.

Panel edge sealing (though a relatively low cost item) shows some possibllities for cost reduction and improved performance. The improved performance involves a vapor tight seal which can improve the life of the panel by protecting against vapor migration from panel edge to interior, and it can also guard against delamination of the panel assembly at its edges and corners.

Efforts have been directed at finding low cost sealants which could be applied in an automated, high throughput environment. This has led to the development of hot melt sealing techniques for application to the edges of encapsulated solar modules.

Array layup and cell interconnection has been seen to be one of the most labor intensive processes of current production facilities. Efforts with this process have therefore been directed toward short range benefits as well as development of long range technologies. To provide a transferrable technology which would be applicable to various cell types and shapes, and various module designs and configurations, programmable automation has been studied.

In order to meet the production quantities desired, processes which are currently being used within the photovoltaic cell industry will have to be scaled up. Many process throughput rates are dependent on the number of wafers or cells handled. For example, in a cell layup and interconnect operation, it does not take four times the time to place and interconnect a four-inch diameter cell (onewatt each) as it does to place and interconnect a two-inch diameter cell (1/4-watt each). This indicates that a desirable trend from an automation standpoint is to increase the size of cells, thereby 
reducing the number to be handled. Some process parameter variation is expected when using larger cell sizes, and therefore these variations have been the subject of some study.

$$
\text { Scale-up studies are also necessary in some batch }
$$

processes due to the variations of process parameters which come about through the use of larger batch sizes. To this end, some of the work performed at ASI has been in the area of higher throughput rates in etching and cleaning operations, diffusion furnace junction formation, and plasma etching for the removal of front-to-back current shunts present after a furnace diffusion.

Economic analysis using the SAMIS system has been performed during these studies to assure that development efforts have been directed towards the ultimate goal of price reduction. 


\subsection{BASELINE PROCESS SEQUENCE DESCRIPTION AND CRITICAL REVIEW}

A process sequence has been proposed with an input of four-inch Czochralski wafers (as sawn) and an output of encapsulated solar arrays. The proposed sequence is shown in Figure 2-1. This sequence has been analyzed for the feasibility of fully automated production techniques capable of producing 200 megawatts per year. (SAMICS baseline company size.) A target volume throughput per production line has been set by MBA at 3,000-3,600 cells per hour for the cell manufacturing 1ine, and 88 panels per hour for the module manufacturing line. This dictates a plant working thrce shifts per day, seven days per week, with six to eight parallel cell lines and one module line.

There is a trade-off in any production line of this nature between batch and continuous process. For some processes where individual processing time is large in comparison to the desired production rates, wafers or materials must be handled in a parallcl or batih uivde. When processing times are shorter, continuous processes can be used. For the proposed cell fabrication sequence an automated batch process is shown in Figure 2-1 to the point in fabrication prior to contact printing. This batch mode is chosen because of the nature of the proven process steps currently being used by the cell manufacturing industry. Contact printing to final panel test and shipment is proposed to be a continuous process because of the nature of the steps involved.

In the proposed process it will be assumed that the wafers are purchased in such quantities that the eontalaris they are recelved in are factory-spectfied and factory- or vendor-supplied. This will aid in simple materials input and handling at the start of the line.

Most of the cell making processes have had significant background work performed in the area of manufacturing equipment. 


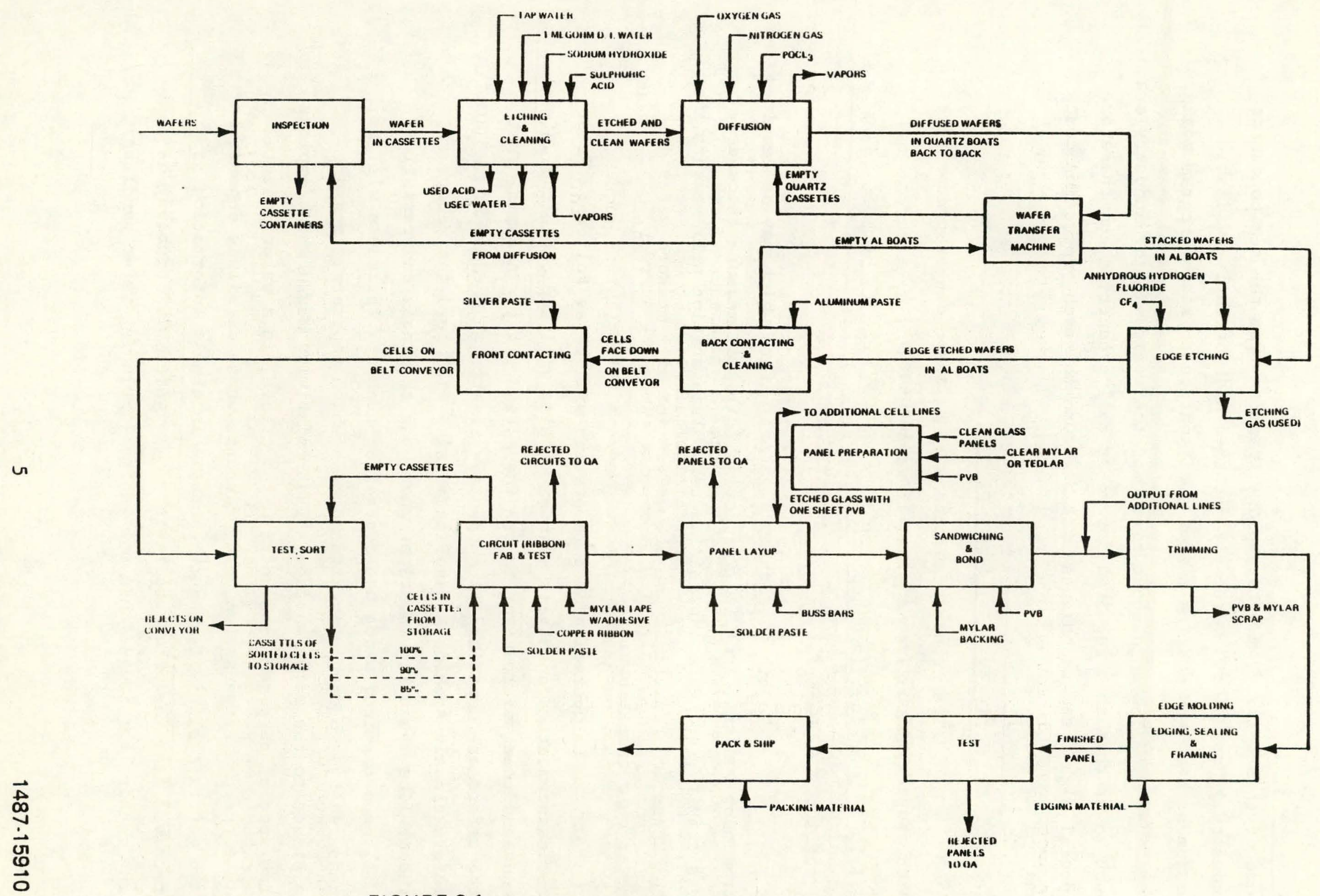

FIGURE 2-1

PROPOSED AUTOMATED SOLAR CELL FABRICATION PROCESS 
Some of this comes from a technology transfer from the semiconductor industry. Most of the currently designed and currently available equipment requires scaling and/or modification to reach program goals.

The throughput rates for the semiconductor industry are much lower than that required for solar cell production and therefore special high speed techniques must be found to reach production cost and volume goals.

\section{$2.1 \quad$ Process Step Descriptions}

The process sequence will be taken one step at a time with a description given and problems discussed.

\subsubsection{Incoming Inspection}

2.1.1.1 Description

To standardize and control wafers which may be received from many vendors, incoming inspection (QA) will measure thickness, resistivity, and wafer shape/diameter. This station will measure the thickness and resistivity of all wafers and will measurc wafer diameter on a sample basis.

Operation of this station will he as follows: Prior to measurement, a specially adapted machine will unpackage the wafers and send them via conveyor to the inspection plant. Assuming that the wafers are contained in a special cassette (possible 50 to 100 wafers closely spaced) a handling machine will feed the wafers to the in-line measuring locations where the thickness and resistivity will be determined using non-contacting probes. Thickness will be measured by two capacitive transducers which separately measure distance to the wafer surface. The resistivity measurement employs two special purpose transducers which create, in a wafer inserted into the gap between them, eddy currents whose magnitude depends on Lhe wafers resistivity and thickness. Thickness information is received from the preceding tester. The wafer will probably be in the machine for longer than one second (including wafer handling) 
but if the indexing cycle for serial events is one second, a production rate of one per second can be achieved. Testing equipment currently avallable could be modified and designed to reach this one second cycle time:

Each lot of cells will be characterized by prediction of expected efficiency based on variations in thickness, area, resistivity and diffusion length of the input material. Information from this station will be input for a central processor which will keep track of the data and enable simplified process control.

2.1.1.2 Input Requirements/Characteristics

- Wafers and incoming carriers.

The incoming wafers are to be in plant supplied and/or specified contalners to allow automated handing. Wafers from inplant slicing stations will be loaded into the specified containers after cutting and purchased wafers w11l be supplied in large enough numbers to make container specification practical. Empty cassettes will return from the diffusion station where the wafers will be transferred from plastic cassettes to quartz cassettes. 2.1.1.3 Output Requirements/Characteristics

- Wafers in plastic cassettes on conveyor to etch station.

The outgoing tested wafers are to be in standard 25 slot polypropylene cassettes. Empty receiving containers will be discarded, returned to plant recelving or cutting station, or shipped to wafer suppliers, depending on final specification.

2.1.1.4 Materlals and Supplies Used

- Silicon wafers (four-inch diameter, .015-inch thick).

- Standard 25 slot cassettes. 
$2.1 .1 .5 \quad$ Equipment Used

- Siltec 2600 series tester/sorter.

- Conveyor to etch station.

- Unpacking machine.

2.1.1.6 Critical Review

This step is presently performed manually. An operator unloads wafers from shipping containers, visually inspects and loads them into cassettes. At the required 3,000 wafers/hour production rate, such manual operation becomes prohibitive. It has already been assumed that volume purchase of sawn wafers will make it economically feasible for LSA facilities to procure the wafers in ready-to-process cassettes. These cassettes can then be automatically introduced into an off-the-shelf thickness/resistivity inspection station. Technology presently exists which will facilitate the development of a totally automated station to perform all the required incoming inspections.

Critical parameters are size, thickness and resistivity for the material and a 3,000 wafer/hour throughput. Automated technology in general, and the semiconductor industry specifically, will allow the required 3,000 units an hour rate required for incoming inspection procedures. Development of a special highspeed machine will be required, but this can be done from proven technology, Thus, no specific verification should be required.

\subsubsection{Etch, Clean and Dry}

\subsubsection{Description}

Thi bllicon uod for this process sequence is in the form of as sawn Czochralski wafers. This station will etch the saw damaged surfaces from the wafer and then, by means of an automated materials handling system, transfer the wafers to a rinse and then to a texture etch bath. (The texture etch will eliminate the need for AR coating of the cells.) The wafers will then be transferred 
to a cleaning and drying station in preparation for diffusion. This process will be performed in a batch mode due to the time required in the etch solutions, with etching and rinsing times regulated by the microprocessor controlled handling system. A system monitoring and controlling conditions in the etch tanks will assure constant etch rates.

2.1 .2 .2

Input Requirements/Characteristics

- Inspected wafers in plastic cassettes.

2.1.2.3. Output Requirements/Characteristics

- Etched wafers in plastic cassettes.

The outgoing wafers will be within specified thickness limits, damaged etched, black texture etched, clean and dry. 2.1 .2 .4

Materlals and Supplies Used

- Sodium Hydroxide

- De-Ionfzed Water

- City Rinse Water

- Isopropyl Alcohol

- Sulphuric Acid

2.1 .2 .5

Equipment Used

- Programmable hoist system such as SEL-REX PCB2000 from Oxymetal Industries.

- Control system for etching tanks.

- Rinsing tanks.

- Etching tanks.

- Cleaning tanks.

- Basket loading/unloading device.

- Feed conveyor to diffusion.

- Linear blow-drier. 
At a production rate of 3,000 wafers/hour this step is not a problem, even though it is a batch process, because the rates are higher than the most limiting step -- diffusion. At present ASI successfully etches 300 three-1nch wafers per cycle in twelve cassettes. Current batch slze increases indicate that the etching characteristics do not change drastically by increasing the lot size and stacking configuration.

It is anticipated, therefore, that 3,000 four-inch wafers can be etched per hour in essentially the same manner but in larger containers, using automated transfer equipment, larger etch tanks and control systems for monftoring and maintaining temperature, solute concentration and solution level. Computer controlled equipment (simflar to what is used in the semiconductor and plating industries) with excellent programing flexibility is available to handle the wafer lot transfer dutles, controlling the etch time accurately and automatically. Precise control of the solution properties ( $\mathrm{pH}$, temperature) w1ll produce constant etch rates allowing high product reproducibility with the required throughput.

The process could also be handled in a semi-continuous processing mode by using long etch bath tanks and moving quantities of cells down the etch line. Very simple overhead carriers and transfer machanisms could be used to transfer cells from one bath to another at preset times. This type of equipment is readily available and has been used in commerclal plating plants.

For those solutions which must be totally replaced af ter processing a given number of cells, speed of solution mixing and heating to process temperature becomes important. A possible solution to this problem is to Include a set of tanks located adjacent to the etching and cleaning line. These tanks would be used for preparing a replacement solution and heating it to process temperature during wafer processing operations of the line. The only time required for replacement 
of solutions would be the time required to pump out the old solution and pump in the previously prepared solution from the adjacent tank. Wafer etching operations could then continue with only this small interruption time.

The basic materlals handiing equipment for this station already exists. Verification should take the form of studies performed concerning etch rates and their dependence on temperature, concentration, agitation and other variables. An optimal control system should be determined including $\mathrm{pH}$ monitoring, $\mathrm{NaOH}$ addition and concentration selection. This system would be simplified by selection of a concentration such that the value of the derivative

$$
\mathrm{d}(\text { etch rate }) / \mathrm{d}(\text { concentration })=0
$$

A convenient tank size will have to be determined in conjunction with control systems, etch rate, heater capacity, etc., and compatible rinsing techniques need to be established to ensure sufficient cleanliness. A cassette stacking machine will be required to assemble the cassettes coming from inspection into the proper batch configuration if this type of batching is ued.

Verification studies of batch size scale-up were performed at ASI. No significant problems were encountered during the transition to etch tanks containing 10 times the volume of solution used previously. While existing capacity is now several mw/year, good results are projected for even larger tanks and higher thioughputs.

\section{$2.1 .3 \quad$ Diffusion}

\subsubsection{Description}

This station will diffuse batches of wafers to provide a uniform junction on one side of the wafer. The system will minimize the amount of diffusant deposited on the back side of the wafers. In order to do this the station will be designed to load two plastic cassettes worth of wafers ( 50 wafers) into 25 slots in a quartz cassette for back-to-back diffusion. The quartz boats will automatically be inserted into a diffusion furnace for $\mathrm{POCl}_{3}$ diffusion and 
automatically withdrawn at the end of the cycle. The equipment for this chemical vapor deposition reaction is well-developed and very reliable. The systems which are currently avallable provide automated diffusion atmosphere control as well as automated quartz boat pulling into and out of the furnace tubes. Interface machinery will be required to load the full quartz cassettes into the boat pulling mechanisms. The transfer tasks will be done in the diffusion room so that the quartz cassettes and other items going into the diffusion furnace do not leave the diffusion room. This room has the highest level of cleanliness in the cell fabrication area.

A furnace with multiple eight-inch diffusion tubes with time, temperature and gas flows optimized will be required to meet a target of 3,600 cells per hour with a unfform sheet resistance of approximately 40 ohms per square.

An alternative approach to junction formation may be to ion-implant the wafers. It should be noted that this process requires relatively high cost equipment, and equipment to operate at the target volumes requires some develnmment: The diffueion furnnon. was chosen as a baseline here because of its current availability and performance.'

$2.1 \cdot 3.2$

2.1 .3 .3

2.1 .3 .4
Input Requirements/Characteristics

- Clean etched wafers in plastic cassettes.

Output Requirements/Characteristics

- Diffused wafers in cassettes or on convayor.

Materials and Supplies Used

- Nitrogen

- Oxygen

- $\mathrm{POCl}_{3}$ source 
2.1.3.5 Equipment Used

- Automatic cassette dump load/unload trainsfer machine.

- Two diffusion furnaces with four eight-;inch tubes each, automatic boat pullers, ancl automatic diffusion control.

- Automatic sled loader/unloader.

- Two feed conveyors.

2.1.3.6 Critical Review

It is proposed to use off-the-shelf type diffusion furnaces with already developed pusher/puller and microproizessor systems. Such a furnace including all safety and production control alarms to handle 3,200 four-inch wafers per hour is availatile. The major work here will be to adapt the dump transfer equipment and cassette loader and unloader to automatically put the boats in a sled lined up with the furnace tube.

This step is inherently a batch process in eizch tube and it is planned to use batches as they come from the etching station.

The equipment for this chemical vapor deposit:ion reaction of $\mathrm{POCl}_{3}$ on silicon is well developed and very reliable. ARCO Solar has already performed the initial experiments with diffusion of two wafers per slot back-to-back, and feels this will be very successful. A minimum amount of diffusion source material will remain on the wafer back.

This step is now performed manually at a rate of 100 three-inch wafers per run. The equipment required as the bastic building block for cotal automation is simflar to what is used nor.s. $\mathrm{POCl}_{3}$ diffusion techniques are well established in the semiconductor industry. ARCO Solar currently diffuses 100 threeinch wafers per run in a four-inch diameter tube (typically). 'lhe 
diffusion system proposed would meet the volume goal by diffusing 400 wafers per ruri, stacked two per slot in eight quartz boats in eight-inch tubes.

An important wafer transport function is included in this step. Wafer: coming from the etching station must be transferred two to a silot into quartz boats for diffusion. This should be feasible in an automated fashion using a specially designed machine. this step as the diffusion is currently being done at close to the single diffusion tube rate. This scale-up therefort dues not pose a significant problem. The wafer handing equipment conceived is within the state-of-the-art of manufacturing equipment, but will require special design efforts.

\section{$2.1 .4 \quad$ Edge Etch}

2.1.4.1 Description

This station will take the wafers from the diffuslui station in plastic cassettes and coln stack them in preparation for plasma etching; of the edges. This will eliminate the front-to-back contact tormeri during diffusion. The wafer stackling and loading/ unloading of the reactor will be mechanized and control of the process will be automatic. The etching cycle should last approximately 15-20 minutes, depending upon the batch size.

Th1s process step can alsu be performed after front and back metilization processes have been completed. Edge etching in this manncr only affects the edges themselves. One advantage to performing this process in this sequence is to keep all of the batch processes in one zone, and then process continuously thereafter.

2.1.4.2 Input Requirements/Charactcristics

- Diffused wafers. 
Output Requirements/Characteristics

- Edge etched wafers on a conveyor.

2.1.4.4 Materials and Supplies Used

$$
\begin{array}{ll}
- & \mathrm{CF}_{4} \\
- & 0_{2}
\end{array}
$$

2.1.4.5 Equipment Used

- Etching chamber with automatic load/unload.

- Vacuum pump for etching chamber.

- Wafer stacking equipment.

- Process programmer.

- In-feed, out-feed conveyor.

$.2 .1 .4 .6 \quad$ Critical Review

Plasma etching is new, but ARCO Solar has had parts etched by three different manufacturers of such equipment, LFE, International Plasma Corporation and Tegal Corporation and had good results. It does work, but the current machines are small and have been optimized for use in manufacturing IC's and other fine electronic devices. We feel this process will significantly help LSA achieve its goal of $50 \mathrm{c}$ per watt selling price. The etching rates and throughput of upgraded machines can handle the required 3,000-3,600 wafers per hour without problem.

$$
\text { ARCO Solar is currently using this technique in }
$$

production with excellent results. Plasma etch equipment developed for the semiconductor Indugtry has been applied to batches of 100 four-inch wafers. The desired rate of 3,000-3,600 wafers per hour would, therefore, require eight such tubes assuming a 15-minute cycle.

The equipment used in low-temperature plasma processing is reliable and accommodates a high degree of automation. Special plasma etch equipment may berome available from manufacturers for this 
large volume application. The basic principles involved do not constrain system geometry to the small sizes presently available. Larger systems will allow much larger batch sizes at smaller processing times, and an overall reduction of equipment cost.

\subsubsection{Back Contacting}

\subsubsection{Description}

This station will receive diffused and edge etched wafers on a conveyor, feed them into an automatic screen printer, and print aluminum ink on the back. The wafers will then be dried and fired for back surface field formation. The aluminum which has not alloyed with the silicon will then be etched from the wafer using hydrochloric acid. The wafers are then rinsed and dried and sent on by conveyor to a printer which prints a gridded silver contact on the back.

\section{1 .5 .2}

$2.1 \cdot 5.3$

$2.1 \cdot 5.4$

2.1 .5 .5

\section{Input Requirements/Characteristics}

- Edge etched wafers on a conveyor. Output Requirements/Characteristics

- Silver printed wafers on a conveyor (with aluminum back surface field). Material and Supplies Used

- Aluminum Paste

- Silver Paste

- Hydrochloric Acid

- Rinse Water

Equipment Used

- Automatic screen printer.

- Drying and firing furnace.

- Etch tanks.

- Input and output conveyors. 


\subsubsection{Critical Review}

S1lkscreen-printed aluminum paste works quite well for back contact metallization. When fired, the aluminum paste fuses with silicon to form a low resistance back contact layer. Cell performance can be enhanced by the formation of a back surface field. Aluminum paste is very inexpensive and silkscreening is a proven, high volume, low cost method for applying such paste.

ASI currently prints aluminum paste back contacts on three-inch wafers at a rate of 500 per hour using a manually loaded printer. An Industry survey has been conducted, and automatic printers are avallable which are capable of meeting the 3,0003,600 four-inch wafer per hour goal. Therefore no printing demonstration has been performed. It has been found that etching off the aluminum back contact and applying a silver contact allows uniform interconnect metal systems and techniques. The extra cost for the silver is not as high as a solid back contact, as a gridded silver pattern can be used. This is due to the low resistance created by the alloyed aluminum. Back surface fleld formation depends on proper drying relationships. Verification work which was done on this process is detalled in Section 4.0 .

\section{$2.1 .6 \quad$ Front Contacting \\ 2.1.6.1 Description}

This station will recelve wafers on a conveyor from the back contact station. It will etch the oxide from the front of the cell which has purposely been left on through the back contact step. It will print the front contact on the cell, dry the print, and fire the cell (front and back silver contacts) under the proper conditions for the front contact optimization. Following this step the cells will be transferred to test and sort.

\subsubsection{Input Requirements/Characteristics.}

- Wafers face down on a conveyor. 
2.1 .6 .3

2.1 .6 .4

$2.1 \cdot 6.5$

2.1 .6 .6

Output Requirements/Characteristics

- Completed cells on a conveyor.

Materials and Supplies Used

- Silver Paste

- S11k Screens

- $\mathrm{CF}_{4}$

- $\mathrm{O}_{2}$

Equipment Used

- Automatic loader for printer.

- Automatic screen printing machine.

- Drying and firing furnace.

- Cell flipplng mechanism.

- Input/output conveyors.

Critical Review

The front surface oxide (glass layers) deposited during diffusion is left on up to this point to protect the front junction. This layer is etched away in a Dryox-etcher with a cycle time of approximately 15 minutes. Printing, drying and firing equipment is similar to that used in back contacting and avallable for high speed throughout. No problems are foreseen with this step.

It appears feasible to perform the necessary printing, drying and firing for this step at the desired rates using spectally designed equipment.

\section{1 .7 \\ Test and Sort}

2.1.7.1 Description

This step is for quality control and process monitoring. The station receives the finished cells with exposed ohmic contact pads, ready for lead bonding. 
The station will isolate each cell and individually measure its performance. Based on performance the cell is sorted by class or rejected. Each class is separated, marked and loaded into a "class" cassette. This data is reported through the central process controller to provide process parameter adjustments.

The cells, after they are sorted into relative efficiency classes, can be put into buffer storage. This allows enough cells of the same performance ratings to be accumulated so that they can be put into the same module. This is required to gain maximum efficiency from each module system. The buffer storage is inherently a batch process since the cells are accumulated into a sorted batch.

It is expected that after the production system has been experimented with in a high volume production environment, that overall process control will yleld more uniform results. This is a desirable feature to seek in order to remove the requirement for a batch storage. In this case, the test. station would merely be an accept/refect decision station as far as the mechanics of the product flow are concerned.

The output of this station is therefore working solar cells, and these could be elther packaged for shipment to a module manufacturing company, or they could be input directly to a cell encapsulating line located within the same facility.

2.1.7.2 Input Requirements/Characteristics

- Completed cells on a conveyor.

2.1.7.3 Output Requirements/Characteristics

- Sorted and tested cells in cassettes.

2.1.7.4 Materials and Supplies Used

- Containers for classified cells. 


\subsubsection{Equipment Used}

- Test and sort station.

2.1.7.6 Critical Review

This step possess few problems for meeting the

throughput of 3,000-3,600/hour. Testing equipment is currently available for this station, it remains to interface with a sorting mechanism. Cell orientation should not be a problem as the probes can be designed to contact the metallization on the front irregardless of orientation and the back contact is totally symetrical. Contacts must be exposed and cell handling will be fully automatic.

This proccso is presently used for essentially the same application, but on a smaller scale. Current methods of wafer handling and cassette loading need to be speeded up and automatic cassette feed and release developed. Currently existing equipment should be surveyed and existing designs selected which best lend themselves to rate increase. System/equipment specification and detailed conceptual designs should be developed for automatic loading and unloading of several cassettes within the machinery.

\section{$2.1 .8 \quad$ Circult Fab}

\subsubsection{Description}

There are a few viable techniques which can be used to connect cells into an array in an automated fashion. These basically break into two groups, hard automation and soft automation. There are distinct advantages to either group. The soft automation (or programmable automation) techniques allow a variability in the manufacturing environment. The concept is to use a programmable handing device (industrial robot) with specially designed tooling (end effectors) to handle, place and interconnect cells. Using this technique, different models of a module can be easily accommodated with the same piece of manufacturing equipment. This type of handling is also applicable to various cell types, sizes, shapes and manufacturers. 
The hard automation techniques consist of providing a piece of handling and processing equipment specifically designed and dedicated to a limited task. This type of equipment is generally much faster, and can therefore reduce production and equipment costs, however, it lacks the variability of application available with the soft approach.

A programmable cell assembly station would pickup the cells from cassette unloaders, and place them into a module array (of varlable configuration). Cell interconnect hardware would also be placed, and interconnections completed through the use of speciaily designed tooling at the end of the industrial robot. This technique is slower, and would therefore require several parallel stations to reach the throughput rates. This type of station is currently being experimented with in more detail, and conclusions will be made in future periods.

Concepts for a high speed hard automation station consist of two stage operations wherein a ribbon of series connected cells is manufactured, and at a later process, these ribbons are laid in place in a modular array and connected in parallel. The following description is for the first step of ribbon manufacture.

This station will produce a series-connected ribbon of photocells consisting of a continuous, non-conductive, dimensionally stable carrier tape under the cells and two parallel lead wires between the cells. This method of interconnection was chosen for three reasons:

1) Redundancy of contact points and leads,

2) Ease of handling downstream,

3) Ease of automation at the panel layup step. By omitting one cell and snipping the tape, leads are provided to connect to a buss bar at the panel wiring station. 
- Test and sorted cells in cassettes.

2.1.8.3 Output Requirements/Characteristics

- Ribbons of series connected cells.

2.1.8.4 Materials and Supplies Used

- Mylar tape 1-1/2" $\times .001^{\prime \prime}$ with acrylic adhesive.

- Copper ribbon .002" x .080".

- Solder paste.

2.1.8.5 Equipment Used

- Ribbon circuit fabrication machine.

This piece of equipment must be a specially designed piece of equipment. This will allow the high speed operations necessary to meet goals.

\subsubsection{Critical Review}

The pacing operating for this process is forming bonds between the cells' contact points and the lead wire. While many forms of bonding are used in the semiconductor industry, ASI and MBA feel the solder-paste method currently used by ASI should be used in this process. This method is the most reliable found to date. While other bonding methods (ultrasonic, welding, etc.) are faster and eliminate solder paste dispensing, they are not as rellable. Future work will, however, be performed to study alternate bonding techniques. The automatic cell unload device will be an off-the-shelf automatic wafer unloader.

An infeed conveyor is incorporated into the station and allows the cell to be oriented if required. This can be done using crude pattern recognition techniques by searching for a reference point in the metallization pattern. This orientation station provides a convenfent station for application of solder paste to junction points. 
Making the conveyor narrower than the cell allows application to both the top and bottom junction points simultaneously. It a.l so provides a method of positioning the cell under the soldering heacls prior to the automatic cell transfer device. Lead wires (or flatif: copper ribbon) will be fed from large rolls. Two wires will be fed simultaneously into position between the cell and the soldering tips.

Sketches of these concepts are shown in Figures $2-2$ and $2-3$.

As no similar process or handling equipment exists for this process step, detailed concepts must be developed and detailed design specifications defined. No detailed verification of this haril automation process has been undertaken by MBA at this time. Some work has begun in verification of the soft automation ajpproach.

\subsubsection{Pottant Application}

\subsubsection{Description}

This station will recelve clean, dry gla!ss panels and prepare the module by laying a sheet of pottant (PVB or EVA) on the top surface. This appears to be a straight-forward operation a nd no technical problems are foreseen in its implementation?

2.1.9.2 Input Reguirements/Characteristics

- Clean dry glass panels (consistent cirientation).

- Pottant in sheets or on a roll (PVB or EVt

2.1.9.3 Output Requirements/Characteristics

- Glass panel and pottant on a conveyór.

2.1.9.4 Materials and Supplies Used

- PVB or EVA on rolls or precut sheets.

- Glass panels.

2.1.9.5 Equipment Used

- One panel preparation machine designed and built for this task. 


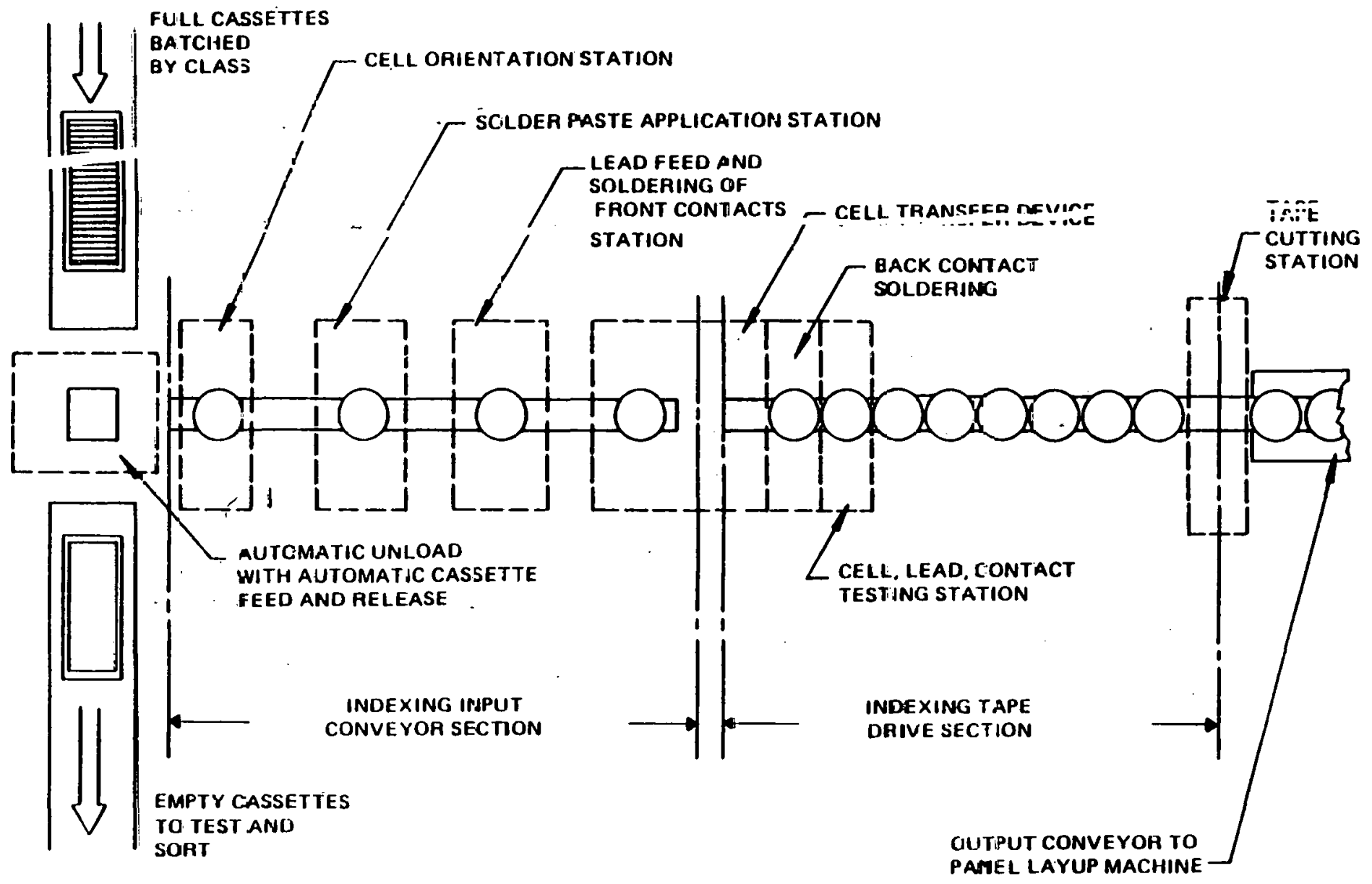

FIGURE 2-2

RIBBON FABRICATION MACHINE 


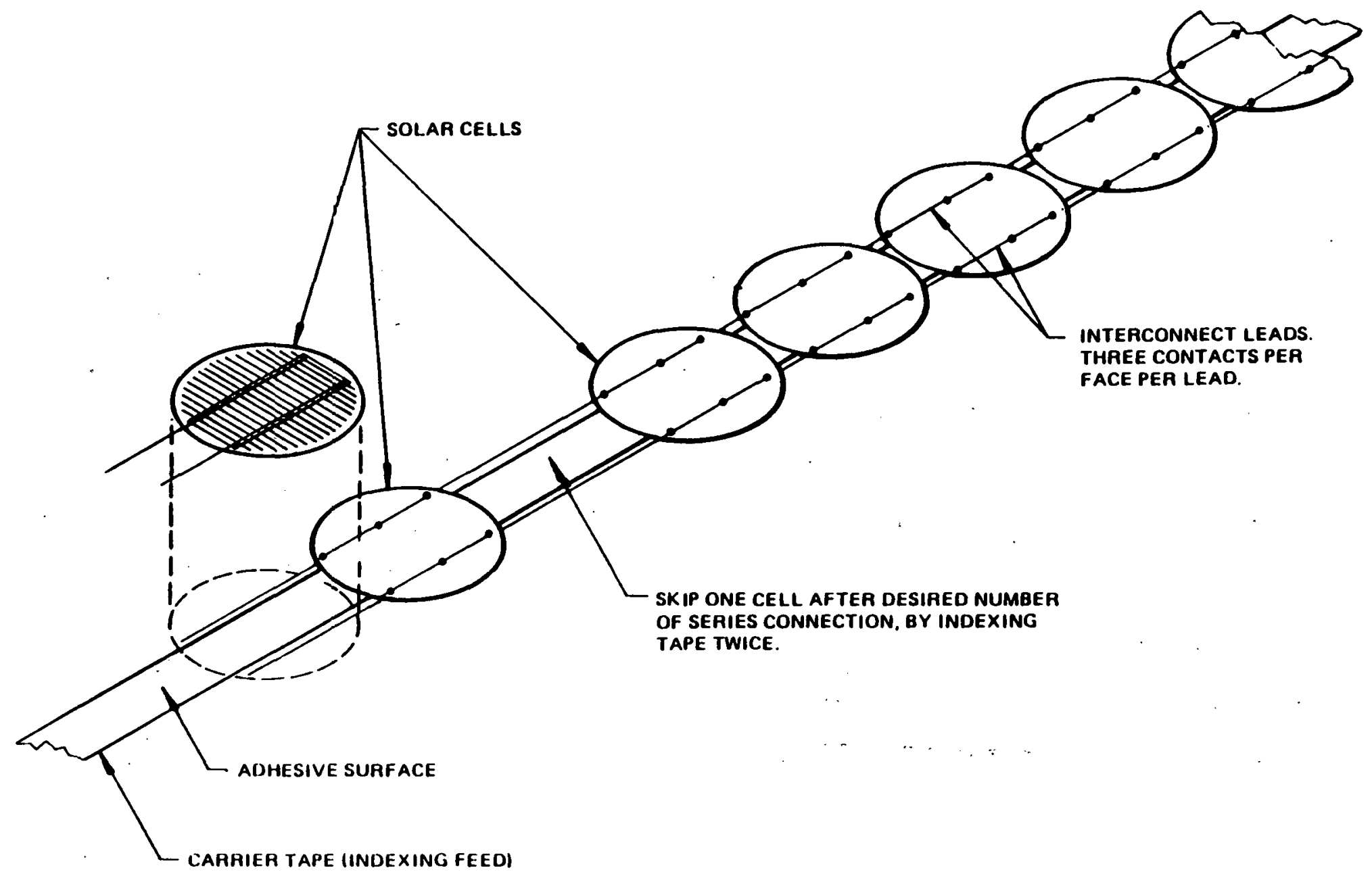

FIGURE 2-3

RIBBON FABRICATION METHOD 
At a production rate of $3,000-3,600$ four-inch cells per hour and a glass usage of approximately 16 square inches per cell, approximately 375 square feet of glass w111 be processed per hour.

To receive, depalletize and clean $1 / 8$-inch thick, 48-inch wide panels at this rate will require automation currently used in industry. It is possible that doubling the rate and operating only half-time may be the most cost-effective manner in which to treat this process.

ASI has shown that by etching the front surface of the glass, reflectivity can be reduced by three-percent, thereby increasing panel effictency. This process can easily be done at a rate far in excess of that required by one cell production line.

This step consists of only a familiar material-handing concept which is currently utilized throughout several other industries. Therefore, detalled verification experiments were not performed in this effort.

\subsubsection{Panel Layup, Wiring and Testing}

2.1.10.1 Description

This station accepts pre-wired circuit ribbons and buss bars, assembles them on the front glass panel and completes the circuit wiring.

It will be built up around an indexing belt which moves each panel stepwise to a specific point where each assembly or test operation is affected. Many automated manufacturing processes employ this technique, so its implementation should pose no inherent problems. The major assembly operation (buss bars and circuit ribbons) occurs at the first stop, and since these items (particularly the ribbons) must be positioned fairly accurately, a holding fixture for the panel will be required. This fixture could be a set of movable stops which 
align and hold the panel during the assembly operation and then automatically release at its completion.

The buss bars will be transferped via an infeed conveyor and positioned on the panel by a vacuum-pickup on an industrial robot. The simplest setup would have the buss bar conveyor perpendicular to the main Indexing belt and wide enough to deliver buss bars, two at a time, to either end of the panel. The robot would be required to move the buss bars in only one direction; rotation or multi-axis motions would not be required. If the panels are sufficiently long, it would be cost effective to split this procedure, that is, provide two separate infeed conveyors and industrial robots, one for each end of the panel.

The circuit ribbon infeed conveyor will run parallel to the main indexing belt with the ribbons aligned in the direction of motion. The ribbons will arrive oriented parallel to their final location on the panel so that they can be transferred to the panel without rotating them. This conveyor need only be wide enough to carry a single row of ribbons since there will be sufficient time, while one is being transferred, to bring up the next. The ribbon transfer machine will be more complicated and accurate than the buss bar transfer machine. It must index laterally so that each ribbon is positioned directly adjacent to the previous one. If the cells are circular instead of square, the transfer machine will also be reyuired to index longitudinaliy to provide optimum packing of the circular cells on the panel. The most critical positioning tolerances will be between the ribbons, hence the inherent indexing accuracy of the ribbon transfer machine is more 1mportant than the positioning relative to the panel. The ribbon infeed conveyor/transfer machine setup will be located opposite the maln indexing belt from the buss bar transfer machine so that both processes can make use of the same holding fixture.

Circuit ribbon leads will be bonded to the buss bars using the same solder-paste technique employed to bond the leads to 
the cells. For panels of the size currently envisioned, the lead bonding machine could eastly solder all of the leads at the same time by providing a set of soldering heads (one for each lead) for both ends of the panel. The individual soldering heads would have to be large enough to compensate for lateral vartations in lead positions from panel to panel. A simplier but more wasteful method would be to solder a continuous strip down the entire length of the buss bar. Lead bonding could also be accomplished using a single row of soldering heads, but this would require indexing each panel two times, (once for each buss bar).

Lead to huss bar bonds will be tested for electrical conductivity by the automatic bond test machine. A set of probes will be placed across each bond, a voltage will be applied and the resulting current measured. The current w1ll be checked at operational levels to preclude false continuity indications. Current estimates indicate that there would be sufficient time to test each bond separately by indexing the test probes from one lead to the next. If this does not prove to be the rase, multiple teet octs could be incorporated with a minimal increase in complexity. An engtneering sketch of this concept is shown in Figure 2-4.

Other techniques are avallabe for panel layup and interconnect. Another technique which shows some promise is to lay up the cells into an array possibly in an interconnect fixture. This would allow the cells to be laid up in confunction with array interconnect pieces. The connections between elements could then be made a.1 at once, possibly in a solder raflow arrangement with atmospheric control. This could reduce electrical connection time by doing them all simultaneously. However, it should be noted that cell and interconnect positioning time may be larger due to the larger distances which must be traversed by an automated positioning tool. 


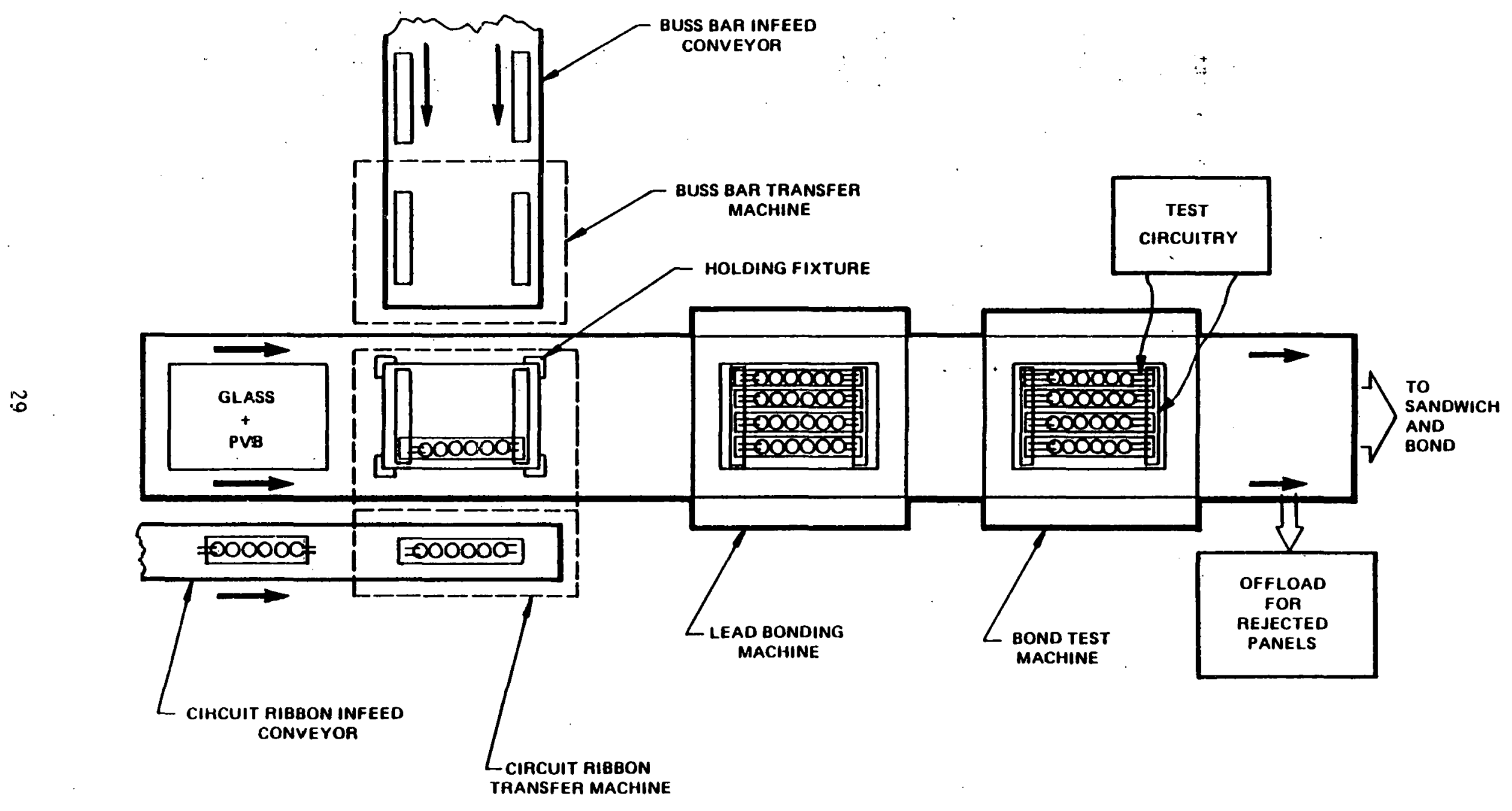

FIGURE 2-4

PANEL LAYUP MACHINE 
2.1.10.2 Input Requirements/Characteristics

- Glass panels with pottant on conveyor.

- Solar cell circuit ribbons.

$2.1 .10 .3 \quad$ Output Requirements/Characteristics

- Subassemblies prepared for final encapsulation process. (This consists of a tested and operating , module).

- Rejected panels removed from process.

2.1.10.4 Materials and Supplies Used

- Glass panels with pottant.

- Series connected ribbons of solar cells.

- Copper buss bars.

- Solder paste in bulk containers/tubes.

2.1.10.5 Equipment Used

- Specially deaigncd handling and sulderluy machine.

- Indexing belt.

- Test station.

2.1.10.6 Critical Review

Although no equipment presently exiets for the automated performance of this step, the soldering technique is similar to that of a ribbon fabrication step. In addition, this step requires a relatively simple $x-y$ ribbon-handling assembly.

Panel layup and cell interconnect processes have had the least amount of work directed to them. This is because wafer handiing and processing has been studied in the past for other semiconductor applications. Continued work and design is needed in this area in order to meet LSA goals. 


\subsubsection{Encapsulation}

$2.1 .11 .1 \quad$ Description

Encapsulation process techniques vary according to the encapsulating system used. Many types of encapsulating materials are feasible, being traded off by performance and cost features. For the purposes of the process sequence and step descriptions, the encapsulating system chosen is a glass superstrate with a pottant of polyvinyl buturayl (PVB) or ethylene vinyl acetate (EVA). A protective plastic back cover of mylar or tedlar is added. This process station would therefore receive interconnected panels, laying on a glass superstrate. This subassembly is transported to this station on a conveyor. The process step here would include adding sheets of PVB and protective plastic preparatory to bonding the panel elements together.

The bond is made by heating the sandwich to approximately $350^{\circ} \mathrm{F}$ while pulling a moderate vacuum on the system to eliminate entrapped air. The heating and vacuum application require a relatively large time allocation, and therefore, to reach a target production rate of 190 panels per hour, special measure must be taken. This may involve either a carousel arrangement where the panels are in the encapsulating machine for a longer period, but the input/output rate matches the 190 panels per hour. The other technique is to do the bonding in a batch mode, heating and pulling a vacuum on several panels simultaneously. This technique requires a buffer storage for panels coming from the layup and test phase and generally increases the process complexity.

Using the carousel arrangement, the module assembly is transferred to the equipment which has receptacles arrayed radially around a common center, and the carousel rotates slowly while the processing progresses. An incoming panel is placed in one of the receptacles, which is simply a depression in the surface, slightly larger and deeper than the panel. A cover plate is pressed over the receptacle, capturing the perimeter of the plastic sheet between itself and the upper surface of the receptacle. A vacuum is pulled via a port in the cover plate, 
pulling the plastic sheet firmly against the plate. A vacuum is then pulled via a port in the bottom of the receptacle, which evacuates the air in the panel assembly. The port in the cover plate is vented to atmosphere while the vacuum to the port in the receptacle is maintained. The protective plastic sheet is thus draped over the entire back surface of the panel, sandwiching all the layers (glass, pottant, cell array, pottant, protective plastic) and eliminating alr bubbles. The receptacle is heated to $350^{\circ} \mathrm{F}$, causing the two layers of PVB to soften and flow to fill the gaps and volds between the glass, cell, and plastic sheet layers and bond them. After the bonding process is completed, heating is stopped, the vacuum is released and the cover plate is pulled away from the receptacle surface. At this point the rotating table has completed one full cycle and the panel is located, removed and passed on to the next processing station.

2.1.11.2 Input Requirements/Characteristics

- Partially fabricated solar panel, with entire array properly oriented and electrically connected.

2.1.11.3 Output Requirements/Character1st1cs

- Panels with protective back cover installed.

- All internal components bonded into a rigid, self-contained unit. Entire unit ready for trimining process.

2.1.11.4 Materials and Supplies Used

- PVB or EVA on rolls or in sheets.

- Protective plastic sheeting on rolls for back of panel (Mylar or Tedlar).

- Size of rolls to be determined by panel dimensions. 
- Pottant cutoff/transfer machine.

- Protective plastic cutoff/transfer machine.

- Vacuum/thermal bonding machine (specifically designed for this process).

- Conveyor and positioning assemblies as required. $2.1 .11 .6 \quad$ Critical Review

This process is presently used on a smaller scale in the present production of solar modules. Up-scaling and automation design should be undertaken in order to verify volume throughput rates desired.

This verification of high speed techniques was not undertaken as part of this work.

2.1.12 Triming and Edge Sealing

2.1.12.1 Description

This step recelves panels from the encapsulation step and trims any flash remaining from the encapsulant system. Trimming is required to prepare the edge surfaces for application of an edge sealant and/or a framing element. Attaining process speeds for trimming to reach the target of 190 panels/hour does not appear difficult, however, no off-the-shelf equipment has been found.

A specially designed machine will accept panels from the encapsulation step off a conveyor and trim any flash remaining with a flying knife. It will then deposit the panel on an output conveyor. The only critical parameter would be that the panels in a given run be of consistent size.

Triming may not be required when the encapsulation process is automated and uniform results provided. The plastic backing was supplied in a larger than module size in order for it 
to act as a vacuum membrane. Special design of the encapsulating equipment could possibly eliminate this requirement.

2.1.12.2 Input Requirements/Characteristics

- Completed module as it is outputed from the encapsulating machine.

2.1.12.3 Output Requirements/Characteristics

- A trimmed panel with no flash ready for framing.

2.1.12.4 Materials and Supplies Used

- None.

$2.1 .12 .5 \quad$ Equipment Used

- One panel trimming machine.

2.1.12.6 Critical Review

MBA can see no technical problems assoctated with

automating this task. Several nearly-identical processes are currently being utilized by various industrles which will reyulie villy slight modification and up-scaling of the basic design concept. Verification demonstrations of trimming were not undertaken during this work.

2.1.13 Edge Sealing and Framing

$2.1 .13 .1 \quad$ Description

Edge seal is required to prevent moisture intrusion into the panel from the edge, as well as to prevent panel delamination at the edges. Edge sealing also could be used as an edge support depending upon the characteristics of sealant used. Edge sealing is especially important when used in conjunction with the baseline encapsulating system proposed here, as the pottants are moisture sensitive. 
Initial edge sealing studies point toward the possible use of a hot melt adhesive application system. Several different types of sealants are available with varying properties, one of the most promising being a butyl sealant which is currently being used for thermopane window glass insulating systems. An advantage of melted sealant application is the short cure time required for the applied sealant bead. This appears to be on the order of 5 to 10 seconds, depending upon the material used. This type of application system also interfaces well with an automated production system as has been demonstrated by numerous can labeling, box gluing, and other packaging techniques being used in industry.

At this station, the encapsulated module comes down a conveyor and the leading edge triggers extrusion of a bead of hot melt adhesive onto the edge of the panel as it passes. Before the adhesive cures, the frames are applied. If edge frames are not required on the panels, the station will merely seal the edges. Flgures 2-5 and 2-6 show an artists conception of the process station.

\subsubsection{Input Requirements/Characteristics}

- Bonded solar cell modules.

$2.1 .13 .3 \quad$ Output Requirements/Characteristics

- Solar modules bonded and framed ready for final test.

2.1.13.4 Materlals and Supplies Used

- Bulk form hot melt adhesive.

- Edge frames fed in with proper orientation.

\subsubsection{Equipment Used}

- Two hot melt extrusion machines.

- Frame hopper/application machine.

- Incoming conveyor.

- Outgoing conveyor. 


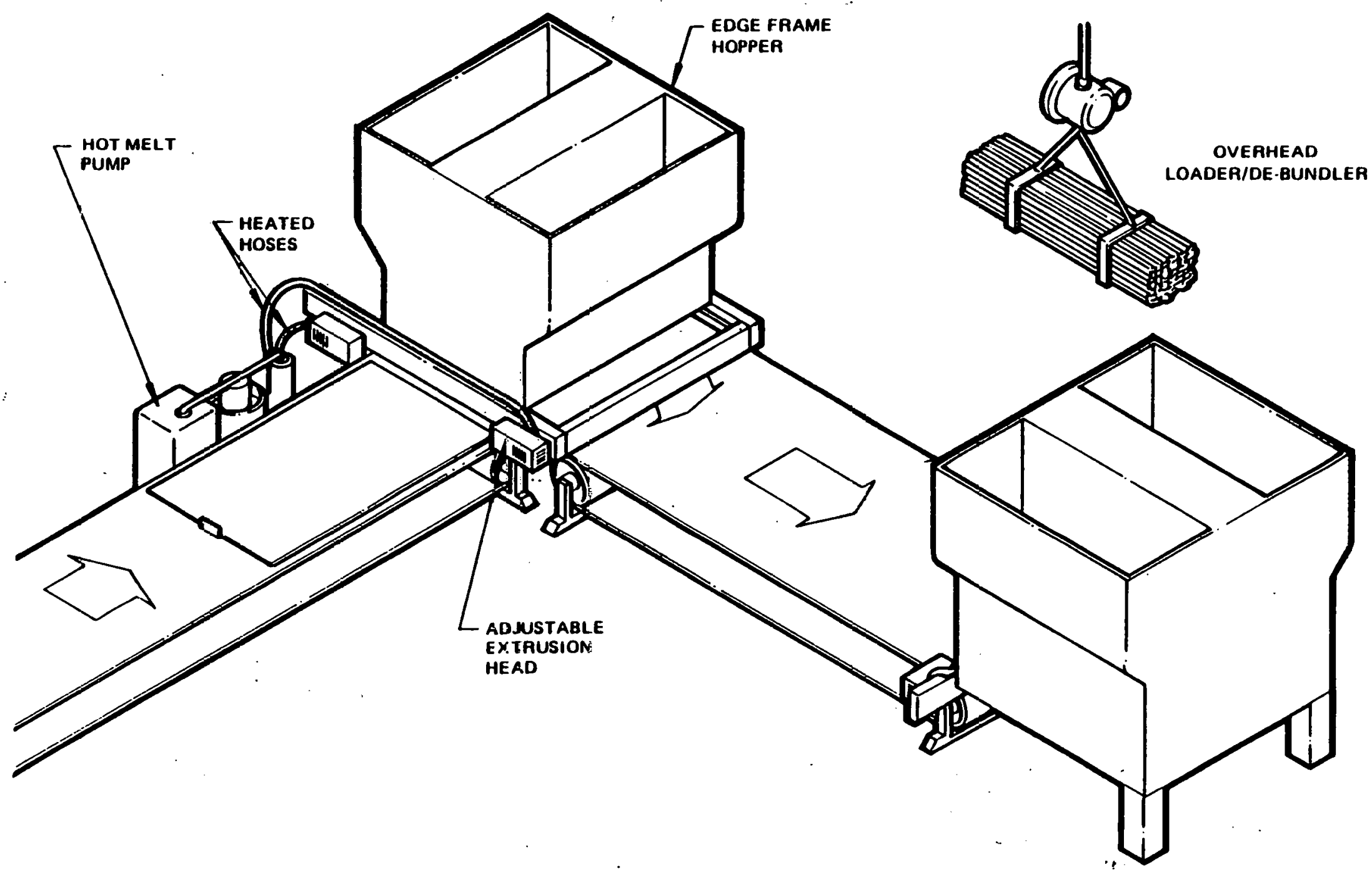

FIGURE $2-5$

MODULE EDGE SEALING STATION 
(A) PNEUMATIC RAM KEYED TO LOCATION OF EXTRUSION HEAD, INITIATTED BY TRAVELING BEAM.

B) TRAVELING BEAM WITH SUCTION GRIP POSITIONS PANEL. IEXTRUSION HEAD POSSIBL Y MOUNTED HERE TO APPLY ADHESIVE TO FRAMEI.

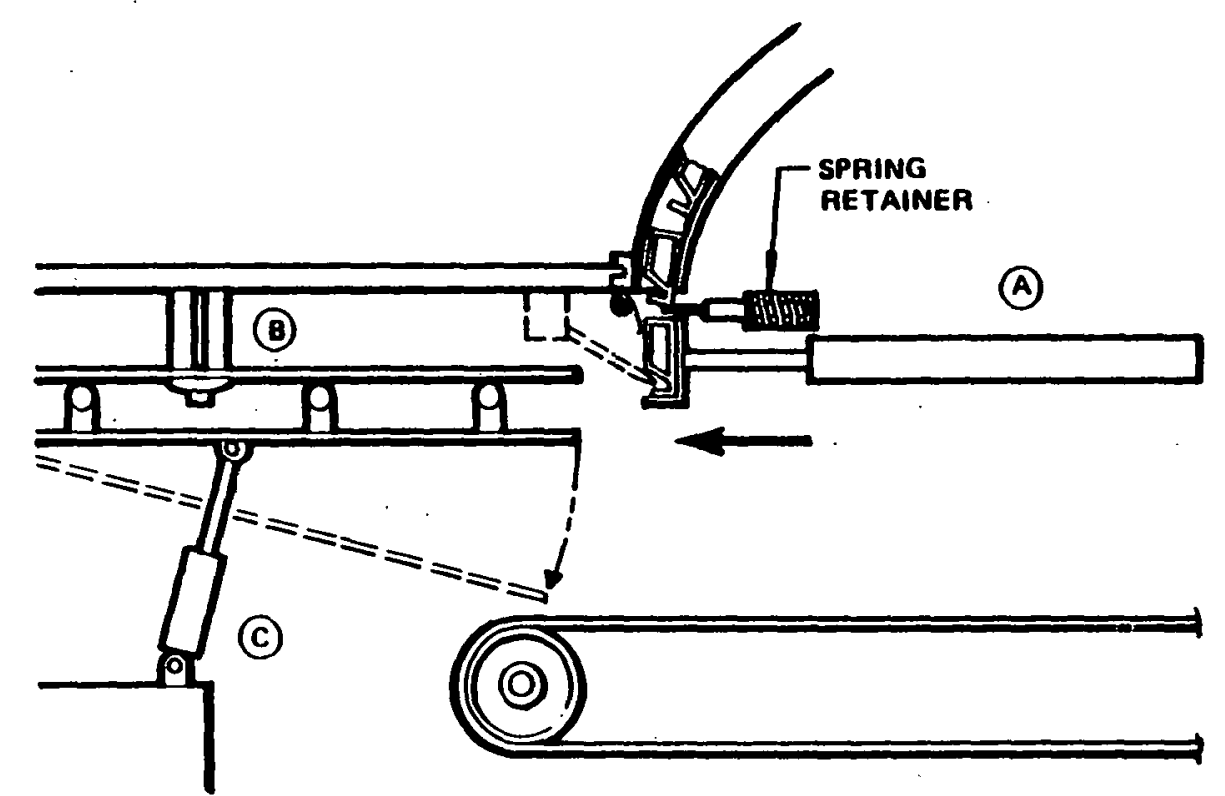

(C) PNEUMATIC RAM KEYED BY RETRACTION OF FRAME POSITIONING RAM LOWEAS TABLE, ALLOWING THE PANEL TO SLIDE ONTO THE NEXT CONVEYOR.

FIGURE 2.6

MODULE FRAMING OPERATION 


\section{$2.1 .13 .6 \quad$ Critical Review}

This step should be well suited for automation. Sealant types and properties for use must be determined prior to equipment design. This work was done in detail under this contract. Conclusions are given in Section 4.0 .
2.1 .14
Final Test

2.1 .14 .1

Description

With the module encapsulated and framed, it must have a. final test to ensure its readiness for shipment. The timing is not too critical, as there are 19 seconds allocated per panel for test. A pulsed solar simulator should be used, and a performance label can be made and applied at this process station. The final performance data should be input into the central processing system to keep process controls updated.

2.1.14.2 Input Requirements/Characteristics

- Completad panelin on n snnvaynr with onntanst. points uncovered.

2.1.14.3 Output Requirements/Characteristics

- Tested and classified panels.

2.1.14.4 Materials and Supplies Used

- None.

2.1.14.5 Equipment Used

- Solar simulatór.

- Label printing and attachment machine.

\subsubsection{Critical Review}

Th1s common process is presently urilized in the same application and will require little, if any, modification. No problems are anticipated in automating the existing procedure. off-theshelf components can be assembled for module handling and testing. 
2.1.15 Packing and Shipping

2.1.15.1 Description

This step should be made as simple as possible to reduce time and materlais. When optimizing final panel size and shape and panel edging and framing, the impact at this step must be considered. A special arrangement of materials handing equipment will be used to palletize the modules.

\section{$2.1 .15 .2 \quad$ Input Requirements/Characteristics}

- Finished, tested modules.

$2.1 .15 .3 \quad$ Output Reguirements/Characteristics

- Packaged modules ready for shipping.

$2.1 .15 .4 \quad$ Materlals and Supplies Used

- Packing crates and materials.

2.1.15.5 Equipment. Used

- Crate wrapping, sealing machine.

- Conveyors.

2.1.15.6 Critical Review

Packaging does not pose too many problems, as long as the system handles the glass panels properly. Considerations for packaging and shipping should be taken into account when designing framing. The modules should probably be palletized, possibly with the same packing that the input glass comes with.

This is a common material-handling situation encountered and successfully accomplished in all manufacturing situations, and requires no verification. 


\subsection{ECONOMIC ANALYSIS OF BASELINE PROCESS SEQUENCE}

The baseline process sequence has been modeled using the Solar Array Manufacturing Industry Costing Standard (SAMICS). The processes were modeled using the SAMICS Format A, and this data was input into the SAMICS computer program.

The process sequence was modeled within a projected 1986 industry. Two companies were formed: Cellco which manufactures cells at a rate of 200 Megawatts/year from as sawn Czochralski wafers, and Module Co. which manufactures solar modules (which have been encapsulated and framed) at a rate of 200 Megawatts/year.

Initial industry simulations resulted in a production volume of $200 \mathrm{Mw} / \mathrm{Yr}$ at a 1986 selling price of $\$ .547 /$ watt (1975 dollars). Further simulations were performed with continual improvements being made to the processes. The most recent simulation (which is more accurate than previous simulations with respect to commodities used): provides a production of $200 \mathrm{Mw} / \mathrm{yr}$ of completed modules which are 4-feet by 8-feet using cells which are $12.3 \%$ efficient. They are produced at a 1986 selling price of $\$ .49 /$ watt (1975 dollars).

The SAMIS system takes all the process parameters and determines a selling price by modeling all direct and indirect costs, as well as modeling profits. Provisions are made for yields within each process. Appendix A gives a copy of the results from the most recent simulation run. Detalls of each process with associated direct and indirect requirements and costs are given. 


\subsection{VERIFICATION STUDIES}

The major efforts under this contract have been directed toward process development and verlfication of only a few steps within the process sequence. Most of the efforts to this point have been in the area of aluminum back surface field formation, and module edge sealing and framing. Additional efforts have been spent in the areas of process scaleup of etching and cleaning processes and plasma edge etch of wafers. Preliminary concept generation and Initial verification demonstration have been performed in the area of automated cell array laydown using an industrial robot. Details of these efforts are given below.

\subsection{Etch and Clean}

\subsubsection{Damage and Texture Etch}

The use of acid mixtures to remove saw cutting damage froti the surface of a silicon slice is a costly and time-consuming process'. Not only are acid etchants expensive, the $\mathrm{N}_{2} \mathrm{O}_{4}$ fumes generated require thorough scubber systems. In addition, the actual quantity of etchant utilized is typically greater than the stoichiometric quantity required. For these reasons, sodium hydroxide has replaced acid. The etch rate is predictable (therefore controllable and does not generate toxic fumes, although the hydrogen evolved in the reaction must be diluted with air to maintain an $\mathrm{H}_{2}$ concentration of less than $4 \%$ (the minimum for flammabllity): ' It should be noced that the technique is not applicable to $1-1-1$ orfentation silicon.

A minimum of $1.5-\mathrm{mlls}$ must be removed from each side of a wafer if that wafer has been cut with an I.D. type saw. (Only 0.5-mils need be removed if the slices have been cut with a slurry saw.) Insufficient materlal removal is evidenced by low open circuit voltage and high leakage currents. When etching silicon wafers, the spent sodium hydroxide is replaced according to the following equation

$$
\mathrm{SI}+2 \mathrm{NaOH}+\mathrm{H}_{2} \mathrm{O}=\mathrm{Na}_{2} \mathrm{SiO}_{3}+2 \mathrm{H}_{2}
$$


For each 28 grams of silicon removed, 80 grams of sodium hydroxide is required and water is added to a fill line on the inside of the etch tank by a float control. The density of sllicon may be taken as $2.23 \mathrm{gm} / \mathrm{cm}^{3}$ except for the first mil of material which is spongy (due to cutting damage) and may be approximated as $1 \mathrm{gm} / \mathrm{cm}^{3}$. After damage removal etching, the wafers are quickly removed to a cascaderinser (to minimize air exposure and staining) in preparation for texture etching. Each basket of slices is then transferred sequentially to another tank containing a low concentration of sodium hydroxide, two to three percent in water, with a small quantity of isopropyl alcohol to precipitate the sodium silicate which forms. The tank is stagnant (except for the hydrogen percolation) and maintained at $80 \pm 1^{\circ} \mathrm{C}$. After 20 minutes in this tank, the 1-0-0 wafers have become texturized (tetrahedral pyramids cover the surface) and are transferred to another cascade-rinser. The reflectance as a function of wavelength is shown in Figure 4-1 for the typical slice produced by this process.

\subsubsection{Pre-Diffusion Cleaning}

The major contaminant in sodium hydroxide is iron. This tends to plate onto the silfcon surface during etching and must be dissolved along with any residual sodium hydroxide, although the presence of sodium ions is not as deleterious to device performance as with other types of semiconductor processing. This function is accomplished through the use of sulphuric acld soak ( $3 \%$ in water for a time period of 10 minutes). A low concentration is used to permit complete iron solvolysis without re-deposition as an insoluble salt and it is neutralized by dumping with the sodium hydroxide contained in the texturization tank. Another cascade-rinse station follows the acid bath and the wafers are now spun dry in a commercially available spinner rinser.

ASI has etched 400 three-1nch wafers per hour using the process described. The sodium hydroxide replacement technique was shown to be a satisfactory production procedure for 12 continuous 


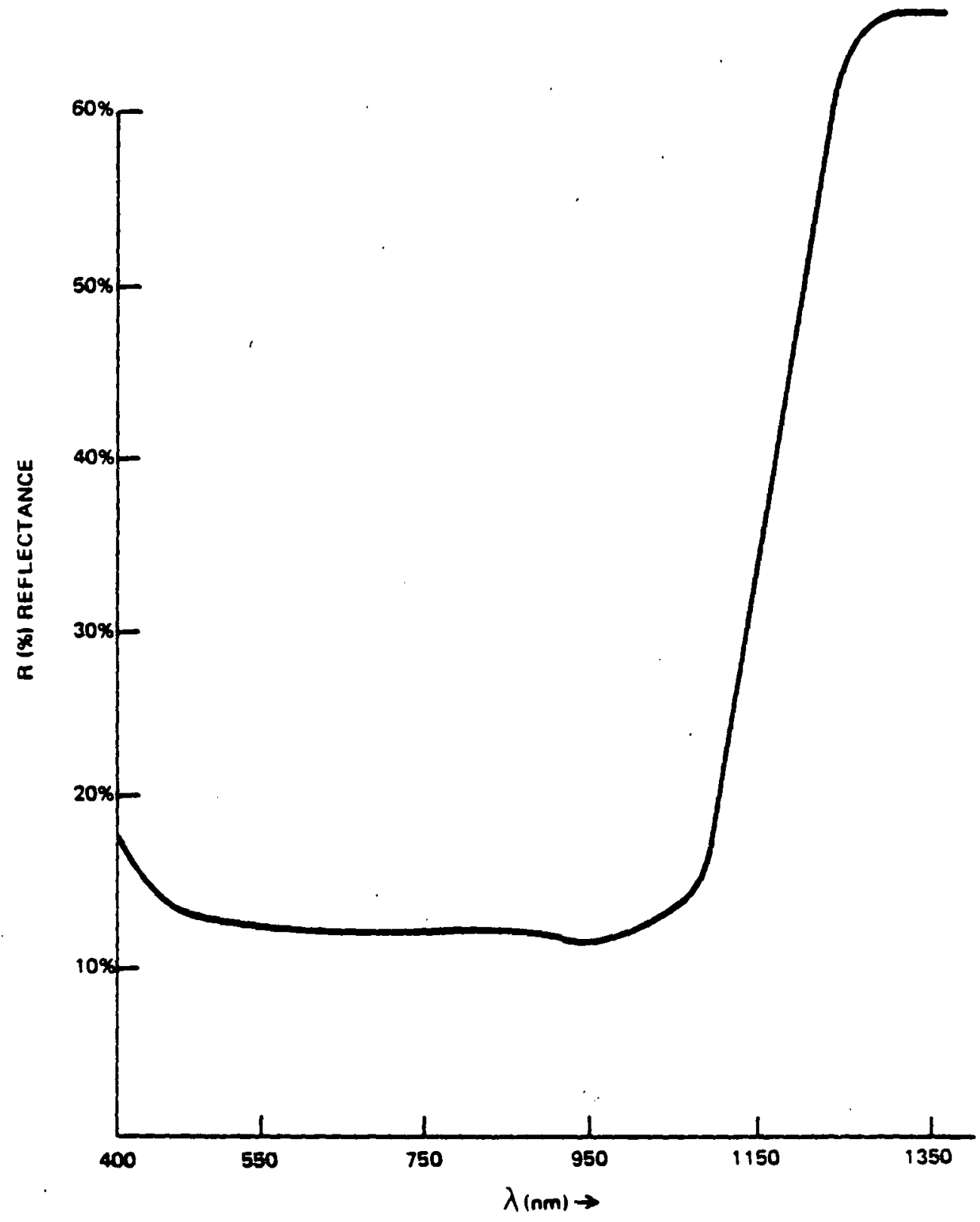

FIGURE 4-1

REFLECTANCE FROM TEXTURIZED SURFACE OF 10.0 SILICON 
300 wafer lots. The wafer-to-wafer and batch-to-batch uniformity being well within a production tolerance of \pm 1 mil. Process control equipment will be specified for monitoring and malntaining the solution conditions by gradual addition of sodium hydroxide.

\subsection{Edge Etch}

The proposed cell making process sequence includes a chemical vapor deposition and diffusion step to provide junction formation. The technique used to mask the back of the wafer from receiving a large quantity of dopant is to diffuse the wafers with two. inserted in each quartz cassette slot. In this manner, the wafers mask each other. The cdgca of the wafers levelve a large quantity of dopant, and the backs of the wafers receive a varying dopant layer which falls off to zero at the center of the wafer back. This imperfect masking provides a current short of the cell front-to-back and must therefore be removed. Conventionally this has been removed through the use of wet acid back etch. The desire to remove the requirements for an intermediate wet etch step has led to invest1gations of other techniques. ARCO Solar originally proposed the substitution of plasma back etch for chembal wet etch. During experimentation with back etching, it was found that the desired performance could be arrived at by removing only the diffused edge of the wafer. This technique removes a back etch process, but adds a plasma edge etch.

Several cechnlques for macerials handing through such a station could be used. Edge etching in a moderate size plasma etcher requires approximately a 15 minute sequence. Wafers are loaded into the reactor, on boats or fixtures made of aluminum, glase or plastic. Then the reactor is sealed, and evacuated by a mechanical pump. Gas flows into the reactor, passing between electrodes that supply electrical energy (from a RF generator) to convert the gas into plasma. Gas flow, electrical power input, processing time and other variables are governed by a control unit. 
The gases used most frequently to generate plasmas for manufacturing process are oxygen, argon and freon 14. They are inexpensive and are readily available in cylinders from suppliers of industrial gases.

One technique which can be used to mask the front and back surfaces from being etched during the process is to design a carrier which holds a stack of wafers with the front and back surfaces of adjacent wafers in contact. Loading into and out of a plasma etcher could be done manually or with an automatic loader/ unloader.

Cells are currently being edge etched by coin stacking and exposing them to a $\mathrm{CF}_{4}+\mathrm{O}_{2}$ plasma for a period of about ten seconds per wafer. The plasma etching apparatus for accomplishing this task is similar to that disclosed in U. S. Patent 3795557.

4.3 Aluminum Back Contacts and Back Surface Field Formation

4.3.1 Background

The use of a back surface field to create an acceptor gradient at the back side of a solar cell has the following advantages:

1) An increase in open circuit voltage is observed for all resistivities greater than $0.8 \mathrm{ohm}$ centimeter.

2) The short circult current of the solar cell is enhanced, particularly for bulk resistivities in the range of 0.8 to $1.0 \mathrm{ohm}$-centimeter. This is a result of increased long wavelength response. This particular effect is of substantial significance in optimization of poly-crystalline device performance.

3) A back surface field provides a greatly reduced back contact sheet resistance. Sheet resistance 
on the order of one to five ohms per square are typical. This low sheet resistance makes it feasible to utilize a gridded back contact pattern.

4) The curve fill factor obtained for high resistivity devices is substantially improved over that of a non-field solar cell.

Although any conventional acceptor materials such as boron, aluminum, gallium or indlum may be utilized to form the back surface field, the greatest success has been achieved while utilizing aluminum. Aluminum is an ideal material because of its capability to dope silicon to high levels $\left(10^{18}\right)$, and because it alloys with silicon at a relatively low temperature $\left(557^{\circ} \mathrm{C}\right)$. This alloying action makes it possible to form the sharp junction which is essential for optimized back surface field performance.

The alloying action is also capable of gettering substantial quantities of impurities from the bulk of the silicon. I'his particular effect has not yet been optimized on a production basis but offers the possibility of manufacturing efficient solar cells from metallurgical grade silicon. The back surface field impacts crystal growing technology, both because it is effective with any silicon crystal orientation, and because the allowable resistivity spread for any given slice is quite large. The back surface field further opens options in sawing technology because it permits full efficiency devices to be manufactured from slices only five mils thick. Finally, aluminum is the 1deal back surface field material because it provides a low cost back contact which is environmentally stable and because it segregates the unwanted parasitic diffusion normally removed by wet processing techniques from the back side of a solar cell.

\subsubsection{Prior Techniques Utilized in Formation of Aluminum Back Surface Field}

Since 1972 evaporated aluminum has been utilized as the primary method for obtaining a back surface. The technique 
typically employs vacuum deposition of an aluminum layer between 5,000 angstroms to 8 microns thickness. Following this aluminum evaporation an alloy sequence is accomplished. The sequence typically consists of heating for periods of 10 to 30 minutes at a temperature of 750 to $900^{\circ} \mathrm{C}$. Although the technique is often effective, it is quite erratic in formation of a fully enhanced back surface field, evidenced by a greatly improved open circuit voltage. The unpredictability of the evaporated aluminum method as well as the lack of a high yield of fully enhanced devices has made it a cost ineffective technique.

In 1975, experiments were begun to fully characterize the reason for this lack of process control. The most significant variable apparently is the interfaclal layer between the aluminum and silicon. An alternative technique has been devised which involes utilization of aluminum powders as the source for the acceptor material. Upon heating an aluminum powder material in an oxidizing atmosphere, a highly exothermic reaction occurs. Th1s reaction overcomes the initiation problems encountered with evaporated aluminum layers and has been demonstrated to provide nearly 10 millivolts more open circuit voltage in completed devices than was observed with the best of evaporated aluminum layers. The significant variables associated with the powder process are the thickness and temperature profile associated with field formation.

Inftial work was performed by printing aluminum on wafers and firing them in a open tube. Silicon wafers of three-inch diameter were diffused and printed with both comercially avallable e.g. Englehard A 3484 and Plessy LP19-4662 and ARCO Solar aluminum paste. All paste materfals were fired at $900^{\circ} \mathrm{C}$ in an air atmosphere fur times periods of 40 to 60 seconds in an open tube. This type of procedure had been previously utilized successfully for two-inch diameter wafers but never for three-inch sizes. The major difference found in going to the large diameter slice was in the time necessary to achieve significant heat transfer for back surface field formation (20 to 50 seconds). 
Mass Production Technology

ARCO Solar has purchased a radiant conveyor belt furnace, Model GS-800, from Radiant Technology in Cerritos. This furnace was used to.demonstrate the feasibility of mass production techniques for back surface field formation on devices more than four times larger in area than any previously successful back surface field device. Initially difficulties were encountered in transferring the small scale tube firing technique to tigh throughput belt processing. The significant variables identified and characterized during the course of this work included heat up, soak and cool down time wilh the furnace. Each of these fiactors must be optimized in coordination. The first variable, heat up time, was found to be most important. During this period, it is necessary to drive off the volatile organic materials of the plasticizer binder and initiate the exothermic reaction which is a key to successful field formation. The lamps within the radiant heated furnace were adjusted so as to provide for this hot entrance zone requirement. The suak LIme was governed by the necessity to heat the wafer to a temperature between 700 and $900^{\circ} \mathrm{C}$, but to maintain it at this temperature for a short period (approximate1y fo sesonds).

Three-inch cell.s with an aluminum paste back contact were successfully fired on this conveyor belt furnace to yield the current and voltage enhancement typical of back surface field formation. The aluminum paste was printed and dried at 200 degrees centigrade. Wafers were passed through the furnace at a rate of 2.08 feet per minute with the maximum power settings possible. The cells were above the aluminum silicon eutectic $\left(557^{\circ} \mathrm{C}\right)$ for a pertod of 90 seconds. These tests were performed with material of a nominal resistivity of 5-25 ohm-cm. The starting lifetime of the material was questioned and high purity IC grade wafers were tried.

A number of three- and four-inch wafers were fired on the conveyor belt furnace. The aluminum paste utilized in these 
experiments was Englehard A3484. The paste contained no frit materials and was printed and dried in automated continuous fashion. A substantial improvement was found in the substitution of low concentrations of high viscosity ethelcelulose for the standard grade plasticizer typically found in these paste materials. This improvement was not observed in field formation but in the ability to clean and interconnect to the back side of the slice. A wide range of belt speeds and peak furnace temperature was found to be suitable for optimum field formation and production of low resistance back contacts. Figure 4-2 shows field enhanced three-inch wafers.

After firing, the wafers were reloaded in cassettes and processed through a hydrochloric acid rinse which strips the aluminum dopant source leaving a P+ back. This allows the use of a gridded silver contact to be printed on the back. Less silver can be used because of the low resistance which exists because of the aluminum/silicon alloying. Future improvements in wafer processing should permit retaining the aluminum layer. This is dependent upon devising an interconnection technique for reliable connection to an aluminum contact. One technique may be to use an ultrasonic solder bath to tin the back side of the wafer with complete coverage. This tinning is necessary to seal the backside and prevent galvanic corrosion between the aluminum metallization and the interconnect material.

Since the back surface field as applied by screen printing does not extend to the wafer edge, a slight voltage drop occurs which is related to the area without BSF and the bulk resistivity of starting material. For a full BSF:

$$
J=J_{0} e^{q v / k t}
$$

For a device which is partially BSF ( $A^{\prime}$ ) and partially non-BSF ( $A^{\prime \prime}$ )

$$
J^{\prime}=J_{0}{ }^{q} e^{q v^{\prime} / k t} \quad J^{\prime \prime}=J_{0} e^{q v^{\prime \prime} / k t}
$$




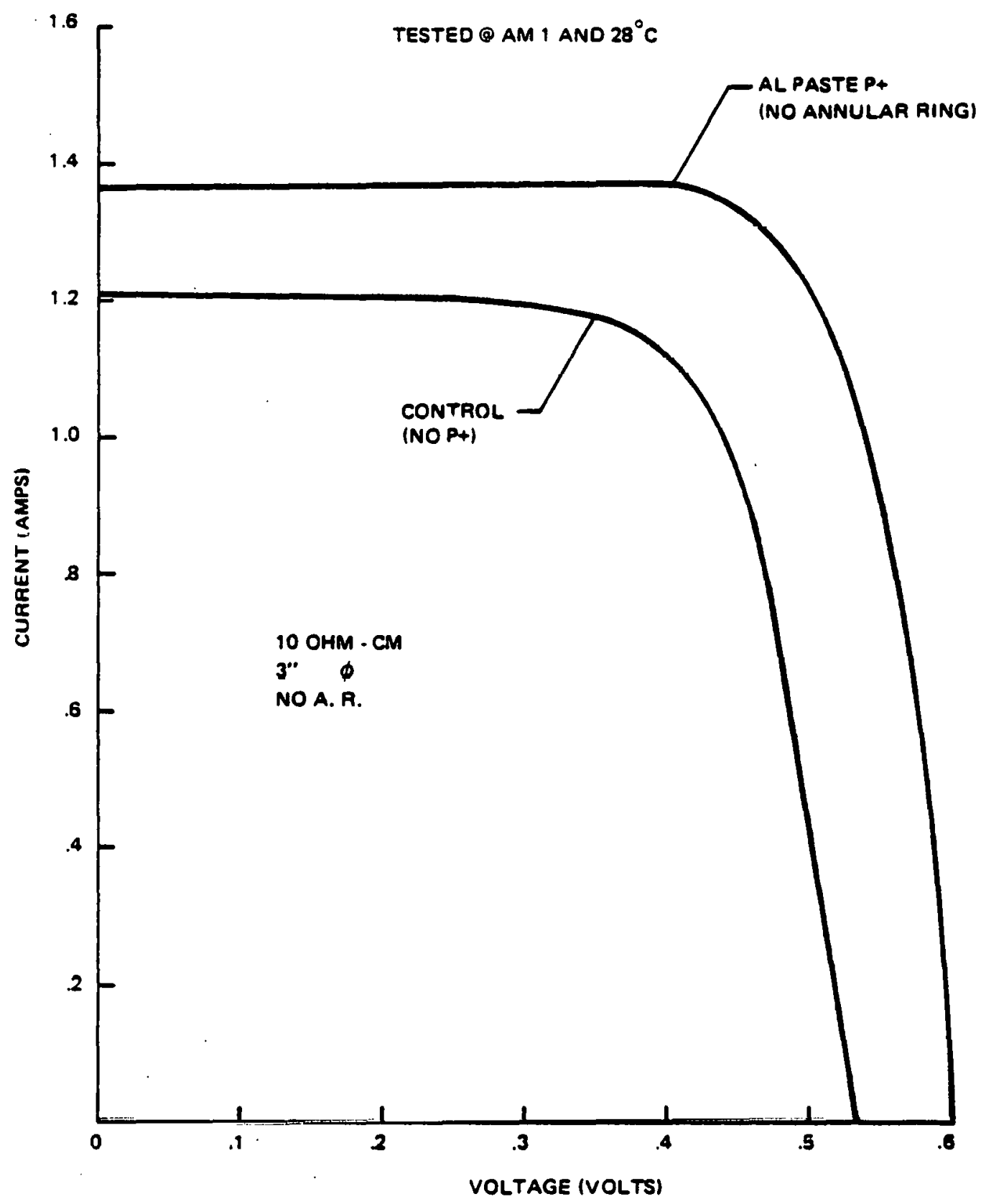

FIGURE 4-2

AL PASTE P+ BACK SURFACE VS. CONTROL 
for

$$
\begin{aligned}
& \text { Area }=A^{\prime} \\
& I=J^{\prime} A^{\prime}+J^{\prime \prime} A^{\prime \prime} \text { if the composite cell has the same } \\
& I_{s c} \text { as } B S F . \\
& J_{0} e^{q v / k t} A=\left(J_{0}^{\prime} A^{\prime}+J_{0}^{\prime \prime} A^{\prime \prime}\right) e^{q v^{\prime \prime \prime} / k t} \\
& e^{q v / k t}=\frac{J_{0} A^{\prime}=J_{0}^{\prime \prime} A^{\prime \prime}}{J_{0} A}=e^{q v^{\prime \prime} / k t} \\
& v-v^{\prime \prime \prime}=\frac{k t}{q} \operatorname{In}\left(\frac{A^{\prime}}{A}+\frac{J_{0}^{\prime \prime}}{J_{0}} \frac{A^{\prime \prime}}{A}\right) \\
& v-v^{\prime \prime \prime}=\frac{A^{\prime}}{q}=A-A^{\prime \prime}
\end{aligned}
$$

at short circuit, assume $J_{s c}{ }^{\prime}=J_{s c}{ }^{\prime \prime}$, and at open circuit, assume

$$
\begin{array}{lc}
v_{o c}=v_{o c}{ }^{\prime}=.595 & v_{o c}^{\prime \prime}=.520 \\
V-V^{\prime \prime \prime}=0.0259 \ln \left(1-\frac{A^{\prime \prime}}{A}+18.1 \frac{A^{\prime \prime}}{A}\right)
\end{array}
$$

This allows the plot shown in Figure 4-3 to be made for $V_{\text {oc }}$ loss as a function of the annular margin on a four-inch cell.

\subsection{Array Layup and Cell Interconnect}

Studies have been performed during this period in the area of automated array layup. This effort has focused on reaching some of the interim guidelines by using lower cost off-the-shelf type of equipment to handle the lower production throughput. Studies indicate that programmable automation (industrial robots) is applicable to this type of production. Hard automation, however, should probably be used for the high volume goals (500 megawatts per year). Industrial robot system characteristics available and desired handing tasks have been determined. It is desired to use an industrial robot to place cells (and possible interconnect elements) into their module 


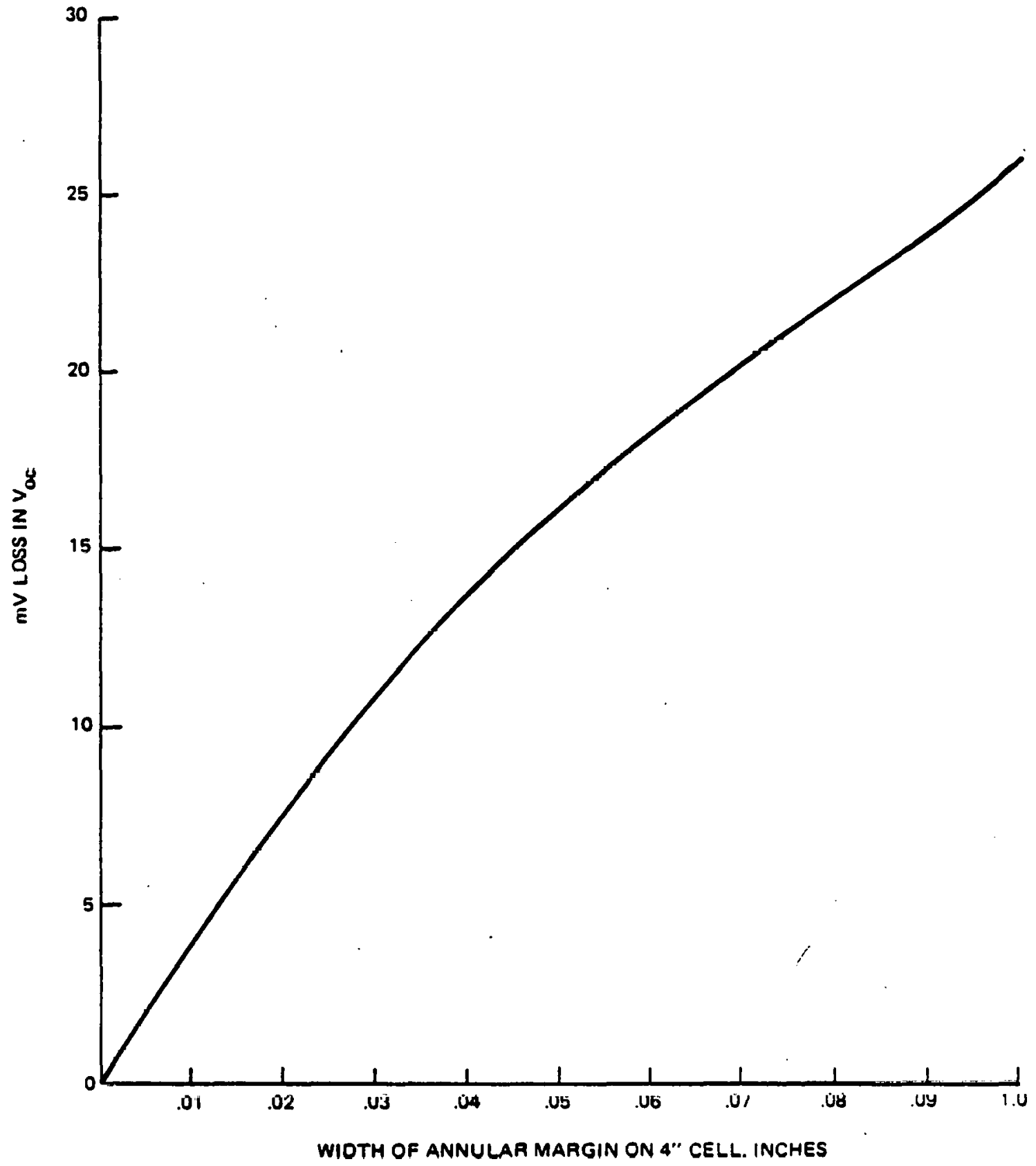

FIGURE 4.3

$V_{O C}$ LOSS AS A FUNCTION OF ANNULAR MARGIN ON A 4" CELL 
array. The system which appears to be general enough for this handling task, and which may possibly be used for other handling tasks within the process sequence, is the Unimate 2000 series industrial robot. Some performance data for this robot is given in Appendix B. Detailed experimentation with this system will begin during the next period.

Conceptual studies have also been started to determine appropriate tooling and/or sensors to be used in conjunction with an industrial robot to provide wafer handling and placement capability. These studies are only preliminary at this stage, and will be continued through the next few months. Accuracy required for the desired tasks must be determined, and means of achieving this accuracy must be implemented. The work recently done by SRI International is applicable here. SRI has taken a Unimate robot and added tooling to the end effectors to allow active or passive detection and compensation for component inaccuracies. Sensing elements could be added to an end effector to ensure that a cell is placed within the desired accuracy in the array.

Conceptualization of operating systems with appropriate end effectors is being done. A system which appears to be applicable for module layup would involve a special end effector (hand) which would include a cassette unloader. This technique would minimize the motions for pick and place to picking up a cassette (or a number of cassettes) and unloading the cells at each laydown location. Initial estimates indicate that a four foot by eight foot array could be layed up in this manner at an average time of approximately two $\mathrm{sec} / \mathrm{cell}$.

Development work has also been done in the area of vacuum pickup of individual cells. It has been found that the vacuum device porting must be carefully designed due to the flexible and fragile nature of the thin silicon wafers. Individual piekup is probably too slow for most of the desired tasks, however, the vacuum techniques can be used for pickup of multiple cells simultaneously. 
Assembling an array of cells also requires interconnection of the cells as an integral part of the process. Two directions are possible to provide this capability. The first is to use an individual interconnection head (solder, ultrasonic bond, etc.) which travels to each cell location. This could be made cost effective if the interconnection head was made an integral part of the end effector. In this manner, a cell would be placed and interconnected during the same operation. A slightly longer time at each array location would be required.

The second approach is through the use of solder reflow techniques. In this way an array of cells and interconnect elements (if used) could be heated in a controlled atmosphere furnace, and the array would be interconnected through one operation. Cell "shingling" techniques (connecting cells back-to-front without an interconnecting element) are also possible in a reflow mode. For reflow, solder could be applied to the cells by dipping, screen printing, or applying solder paste prior to the reflow process.

The work with an industrial robot will continue in much more detall in the next periods. High speed cell laydown and interconnect sequences will be demonstrated, and cost analysis to compare these techniques with hard automation techniques will be performed. 4.5 Edge Sealing and Framing 4.5.1 Edge Sealants

'The panel edge seal, though a relatively simple element, has the potential for increasing the resistance of the array to environmental conditions, aid in prevention of de-lamination, and can bond an edge frame to the panel. Several types of sealants have been considered thus far, with the major driving factor being material cost. With satisfactory sealant performance, cost is the ultimate selector. 
The sealant industry was surveyed and potential materials were examined. The various types include two part polysulfides, gunnable sealants of various types, sealant tapes and hot melt adhesive. Table 4-1 details the sealants examined.

Polysulfides are currently being used in the solar module industry and the insulated window industry with application similar to solar panels. However, the polysulfides are usually two part mixtures, slow curing ( 16 hours to 7 days) and fairly expensive, approximately 3.5 times as expensive as the hot melts. The gunnable sealants either remain a non-hardening putty or have long cure times (3-7 days). The need for rapid throughput of the line makes long cure time an undesirable characteristic. The hot melts typically have open times less than a minute and are inexpensive costing from $\$ .36$ to $\$ .16$ per $4 \times 8$ panel.

\subsubsection{Testing}

There is a wide variety of materials currently being used or considered for encapsulation of photovoltaic modules. After a survey which considered materials used in production at this time as. well as promising candidates for the 1986 goals, the following materials were selected for compatibility testing:

\section{- Glass}

- Wood

- Acrylic

- Polyvinyl Butyral

- Ethelene Vinyl Acetate

- Tedlar

- Silicon

- Glass Reinforced Concrete

- Aluminum 


\begin{tabular}{|c|c|c|c|c|c|c|c|c|}
\hline Sealant & Manufacturer & Type & Form & Application & $\begin{array}{c}\text { Cost } / 4 \times 8 \text { Panel } \\
\text { Cost Watt }\end{array}$ & $\begin{array}{c}\text { (a) } \\
\text { Lifetime! } \\
\text { Weathering: }\end{array}$ & Cure Time & $\begin{array}{c}\text { (b) } \\
\text { Automation } \\
\text { Potential }\end{array}$ \\
\hline 1081 & H. B. Fuller & $\begin{array}{l}\text { Hot Meit } \\
\text { Butyl }\end{array}$ & $\begin{array}{l}\text { Rope or } \\
55 / g a l \text { drum }\end{array}$ & $\begin{array}{l}\text { Hot Melt } \\
\text { Extrusion }\end{array}$ & $\begin{array}{c}\$ .19 \\
\$ .00068 \\
\end{array}$ & Excellent & $10-20$ Secs. & Excellent \\
\hline $\begin{array}{l}\text { Duribbon } \\
72.6417\end{array}$ & $\begin{array}{l}\text { National } \\
\text { Adhesives }\end{array}$ & $\begin{array}{l}\text { Hot Melt } \\
\text { Butyl }\end{array}$ & $55 / \mathrm{gal}$ & $\begin{array}{l}\text { Hot Melt } \\
\text { Extrusion }\end{array}$ & $\begin{array}{c}.20 \\
.00070\end{array}$ & Excellent & $60 \mathrm{Sec}$. & Good \\
\hline $\begin{array}{l}\text { Versalon } \\
1138\end{array}$ & $\begin{array}{l}\text { General } \\
\text { Mills }\end{array}$ & $\begin{array}{l}\text { Hot Melt } \\
\text { Polyamide } \\
\text { Resin }\end{array}$ & $\begin{array}{l}25 \text { Lb. bag } \\
\text { Pellets }\end{array}$ & $\begin{array}{l}\text { Hot Melt } \\
\text { Extrusion }\end{array}$ & $\begin{array}{c}.28 \\
.00100\end{array}$ & Poor & 10 Sec. & Good \\
\hline $\begin{array}{l}\text { Versalon } \\
1140\end{array}$ & $\begin{array}{l}\text { General } \\
\text { Milis }\end{array}$ & $\begin{array}{l}\text { Hot Melt } \\
\text { Polyamide } \\
\text { Resin }\end{array}$ & $\begin{array}{l}25 \text { Lb. bag } \\
\text { Pellets }\end{array}$ & $\begin{array}{l}\text { Hot Melt } \\
\text { Extrusion }\end{array}$ & $\begin{array}{c}.34 \\
.00121\end{array}$ & Poor & $10 \mathrm{Sec}$. & Good \\
\hline 212.069 & $\begin{array}{l}\text { Swift } \\
\text { Adhesives }\end{array}$ & Hot Melt & Billets & $\begin{array}{l}\text { Hot Melt } \\
\text { Extrusion }\end{array}$ & $\begin{array}{c}.16 \\
.00057\end{array}$ & Fair & $32 \mathrm{Sec}$. & Good \\
\hline $212 \cdot 355$ & $\begin{array}{l}\text { Swift } \\
\text { Adhesives }\end{array}$ & Hot Melt & Billets & $\begin{array}{l}\text { Hot Melt } \\
\text { Extrusion }\end{array}$ & $\begin{array}{c}.16 \\
.00057\end{array}$ & Fair & 80 Secs. & Good \\
\hline JM 3764 & $3 M$ & Hot Melt & Cartridges & $\begin{array}{l}\text { Hot Melt } \\
\text { Extrusion }\end{array}$ & $\begin{array}{c}.36 \\
.00128\end{array}$ & Poor & 45 Secs. & Fair \\
\hline 428 & PRC & Polysulfide & $\begin{array}{l}\text { Two Part } \\
55 / g \text { al }\end{array}$ & $\begin{array}{l}\text { Mix and } \\
\text { Pump }\end{array}$ & $\begin{array}{c}.29 \\
.00104\end{array}$ & Excellent & 16 Hours & Poor \\
\hline 438 & PRC & Polysulfide & $\begin{array}{l}\text { Two Part } \\
\text { 55/gal }\end{array}$ & $\begin{array}{l}\text { Mix and } \\
\text { Pump }\end{array}$ & $\begin{array}{c}.25 \\
.00089 \\
\end{array}$ & Excellen: & 16 Hours & Poor \\
\hline 801 & $3 \mathrm{M}$ & Polysulfide & $\begin{array}{l}\text { Two Part } \\
55 / \mathrm{gal}\end{array}$ & $\begin{array}{l}\text { Mix and } \\
\text { Pump }\end{array}$ & $\begin{array}{c}.69 \\
.00246 \\
\end{array}$ & Excellent & $\begin{array}{l}\text { Tack Free - } 20 \text { Hrs. } \\
\text { Cure - } 7 \text { Days }\end{array}$ & Poor \\
\hline 612 & $3 M$ & Polysulfide & $\begin{array}{l}7 \text { Lb. } \\
\text { Package }\end{array}$ & $\begin{array}{l}\text { Pressure } \\
\text { Flow Gun }\end{array}$ & $\begin{array}{c}.68 \\
.00246\end{array}$ & Excellent & $\begin{array}{l}\text { Non-Hardening } \\
\text { Putty }\end{array}$ & Poor \\
\hline 5354 & $3 M$ & $\begin{array}{l}\text { Butyl } \\
\text { Tape }\end{array}$ & $\begin{array}{l}50^{\prime} \text { Roll } \\
3 / 8^{\prime \prime} \times 1 / 8^{\prime \prime}\end{array}$ & - & $\begin{array}{c}1.32 \\
.00471 \\
\end{array}$ & Excellent & Non-Hardening & Poor \\
\hline 404 & $3 M$ & $\begin{array}{l}\text { Synthetic } \\
\text { Elastomer }\end{array}$ & 55/gal drum & $\begin{array}{l}\text { Pressure } \\
\text { Flow Gun }\end{array}$ & $\begin{array}{c}.14 \\
.00050\end{array}$ & - Good & $\begin{array}{l}\text { Tack Free }-2 \text { Hrs. } \\
\text { Cure - } 3 \text { Days }\end{array}$ & Poor \\
\hline 5200 & $3 M$ & $\begin{array}{l}\text { Synthetic } \\
\text { Elastomer }\end{array}$ & $55 / g a l$ drum & $\begin{array}{l}\text { Pressure } \\
\text { Flow Gun }\end{array}$ & $\begin{array}{c}.32 \\
.00114\end{array}$ & Good & $\begin{array}{l}\text { Tack Free - } 48 \text { Hrs. } \\
\text { Cure - } 7 \text { Days }\end{array}$ & Poor \\
\hline 4050 & $\begin{array}{l}\text { National } \\
\text { Adhesives }\end{array}$ & $\begin{array}{l}\text { Butyl } \\
\text { Sealant }\end{array}$ & $\begin{array}{l}\text { Tape or } \\
55 / g a l \text { drum }\end{array}$ & $\begin{array}{l}\text { Pressure } \\
\text { Flow Gun }\end{array}$ & $\begin{array}{c}.20 \\
.00078\end{array}$ & Good & $\begin{array}{l}\text { Tack Free - } 3 \text { Hrs. } \\
\text { Cure - } 3 \text { Days }\end{array}$ & Poor \\
\hline
\end{tabular}

(a) Based on manufacturer supplied information.

(b) MBA opinion based on cure time, application, equipment needed.

TABLE 4.1

EDGE SEALANTS 
It is felt that testing of these materials will cover a broad range of encapsulation schemes. Three module designs were decided upon as follows:

Module No.

Materials Glass, PVB, Tedlar. Acrylic, EVA, GRC 3 Acrylic, Silicon, Wood

Preliminary applicability, adherence, and molsture resistance tests have been performed with a number of possible sealant types. These tests were performed by applying the sealant to strips of mylar (the more difficult element of the laminated assembly to adhere too) under various preparation conditions. Table 4-2 gives the sealants experimented with during this period along with preliminary results and performance judgements.

The hot melt systems appear to be the most applicable, with the butyl based type performing espectally well. The 1081 Butyl manufactured by the HB Fuller Co., shows much promise. Appendix C gives some performance data for this type of sealant.

These sealants have also been used extensively for hermetic sealing of thermo-pane insulating windows. Performance requirements for insulated glass are similar to those for edge sea1ing of solar modules. Sigma (Sealed Insulated Glass Manufacturers Association) has set up accelerated weathering tests for 1nsulated glass. CE Glass, a manufacturer of insulated glass has performed extensive testing of HB Fuller 1081 butyl sealant comparing its performance to polysulfide. Appendix D gives the Sigma weathering test procedures as well as the CE Glass test procedures used for the butyl weathering tests. The less expensive butyl (approximately $\$ 1.25$ per pound) was shown to perform better than the polysulfide in all cases.

Further testing of these sealants will be done by applying them to the small laminated solar panels. This will be done during the next period. 
TABLE 4-2

SEALANTS TESTED

\begin{tabular}{|c|c|c|c|c|}
\hline SEALANT & MANUFACTUFER & TYPE & HOW APPLIED & RESULTS \\
\hline Hydro-Seal & $\begin{array}{l}\text { American Energy } \\
\text { Group }\end{array}$ & Acrylk-Latex & Dipped & $\begin{array}{l}\text { Did Not Adhere } \\
\text { to Mylar }\end{array}$ \\
\hline Acrylic Cement & Tap Plastic & Acrylic & Dipped & \\
\hline $12-355$ & Swift & Hot Melt & $\begin{array}{l}\text { Heated, then } \\
\text { Dipped }\end{array}$ & $\begin{array}{l}\text { Good Adhesion } \\
\text { Slow Cure }\end{array}$ \\
\hline $12-069$ & Swift & Hot Melt & $\begin{array}{l}\text { Heated, then } \\
\text { Dipped }\end{array}$ & $\begin{array}{l}\text { Good Adhesion } \\
\text { Rapid Cure }\end{array}$ \\
\hline Sealer 5354 & $3 M$ & $\begin{array}{l}\text { Synthetic } \\
\text { Rubber }\end{array}$ & By Hand & $\begin{array}{l}\text { Good Adhesion } \\
\text { Non-Hardening }\end{array}$ \\
\hline $\begin{array}{l}\text { Industrial } \\
\text { Sealant } \$ 612\end{array}$ & $3 M$ & $\begin{array}{l}\text { Oil Resistant } \\
\text { Elastomer }\end{array}$ & By Hand & $\begin{array}{l}\text { Adheres After } \\
30+\text { Minutes }\end{array}$ \\
\hline $\begin{array}{l}\text { Industrial } \\
\text { Sealant } \# 801\end{array}$ & $3 M$ & $\begin{array}{l}2 \text { Port } \\
\text { Polysulfide }\end{array}$ & Spatula & $\begin{array}{l}\text { Takes } 7 \text { Days } \\
\text { to Cure }\end{array}$ \\
\hline Thermc.Secl \#1081 & $\begin{array}{l}\text { Distributed By } \\
\text { H. B. Fuller }\end{array}$ & Butyl & By Hand & $\begin{array}{l}\text { Excellent Adhesion } \\
\text { Excellent Drying Time }\end{array}$ \\
\hline $\begin{array}{l}\text { Butyl Rubber } \\
\text { Sealant }\end{array}$ & $\begin{array}{l}\text { National } \\
\text { Adhesives }\end{array}$ & $\begin{array}{l}\text { Gunnable Butyl } \\
\text { Rubber }\end{array}$ & Gun Applied & $\begin{array}{l}\text { Good Adhesion } \\
\text { Remains Flexible }\end{array}$ \\
\hline
\end{tabular}


4.5.3 Application and Framing

Automation of this process is dependent upon the type of sealant considered. With some of the sealants, the panel edges must be dipped into a bath of the liquid mixture. Others can be applied by extruding the sealant onto the panel edge, and the hot melt sealants can be applied by extruding the molten sealant through a heated nozzle. Application techniques are also affected by the type of edge frame used, and how it interfaces with the sealant. If a small channel is used, the sealant may be applied to the channel, and the channel could then be assembled to the edge of the module.

Application equipment for the hot melt sealants is avallable in component form off-the-shelf. This equipment is well developed for high production throughput due to its use in the packaging industry (box or label.gluing, automated assembly). The components avallable must be Integrated into the proposed production Iine: Components are available from various manufacturers (see Appendix E). A central location w1ll take the raw sealant and heat it to a molten state. This station also pumps the liquid through heated lines to the extrusion heads. As a panel comes down a conveyor, its leading edge is detected by a photocell system. This initiates the extrusion of a bead of sealant on both sides of the panel simultaneously. This extrusion can be controlled as to volume and speed, and should be carefully syncronized with the conveyor motions. The trafling edge of the panel is detected by another photocell system, and a valve in the extrusion head terminates the bead. The panel ends can be sealed at the same time by a head which moves along the conveyor axis and applies a bead to the panel in a direction transverse to the conveyor. Another technique which could be used is to move the panel to another conveyor and apply the sealant to the ends in the same manner as the sides. Figures 2-5 and 2-6 show concepts for equipment to apply sealant and frames.

This type of sealant can also be applied by hand using a low cost pump unit and had held gun. This allows this process 
improvement to be used in production to reach some of the interim guidelines for 1980 .

Hot melt sealants become cured enough for handling in about five to ten seconds and therefore they are well sulted to the high throughput desired. The target of 190 panels/hour appears to be an achievable goal with this technique. 


\subsection{CONCLUSIONS AND RECOMMENDATIONS}

Critical review and verification. studies have continued in the areas of plasma etch, aluminum back contact, panel edge sealing, automated array layup/interconnect, and production variations due to large diameter wafers.

Work in plasma etching has reached the conclusion that plasma edge etching is superior to back etching. Verification of this process has been made with production lots of 1,000 being processed with a plasma edge etching technique. Performance of the resulting cells are comparable to those cells being processed in a wet chemical back etch line. Continued production lots are being run using the plasma process.

Aluminum $\mathrm{P}+$ back contacts have been produced in small lots using automated production techniques. Some problems were encountered in direct application to production size lots.

A hot melt butyl based sealant appears to be the most applicable (at this point in time) for low cost module edge sealing. Automation equipment could be designed to allow rapid application of the sealant and/or frame.

Automated array assembly appears to be feasible using an industrial robot for moderate production throughputs. Further work in this area will be performed using an industrial robot to layup modules of various sizes. An arivantage exists in using programmable automation in that one piece of equipment could be used to assemble various panel models merely by changing the program being used by the robot. Interconnection techniques have to be studies in more detail to determine an optimum interface with an automated system.

This work will be performed in future period of this contract. 


\subsection{NEW TECHNOLOGY}

No new technology has been developed to completion

during this period. 
APPENDIX A 


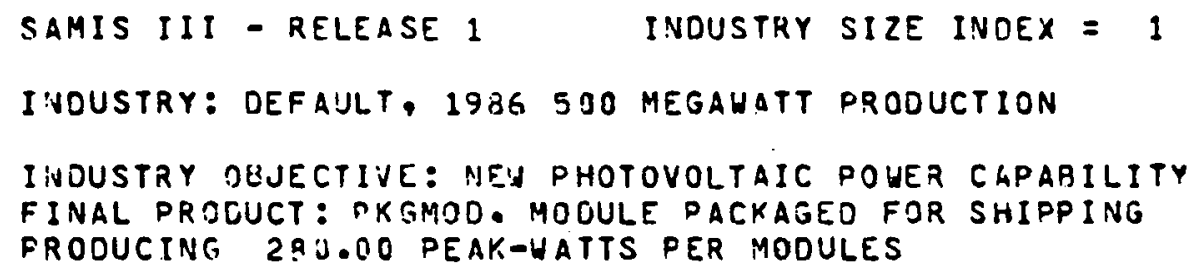




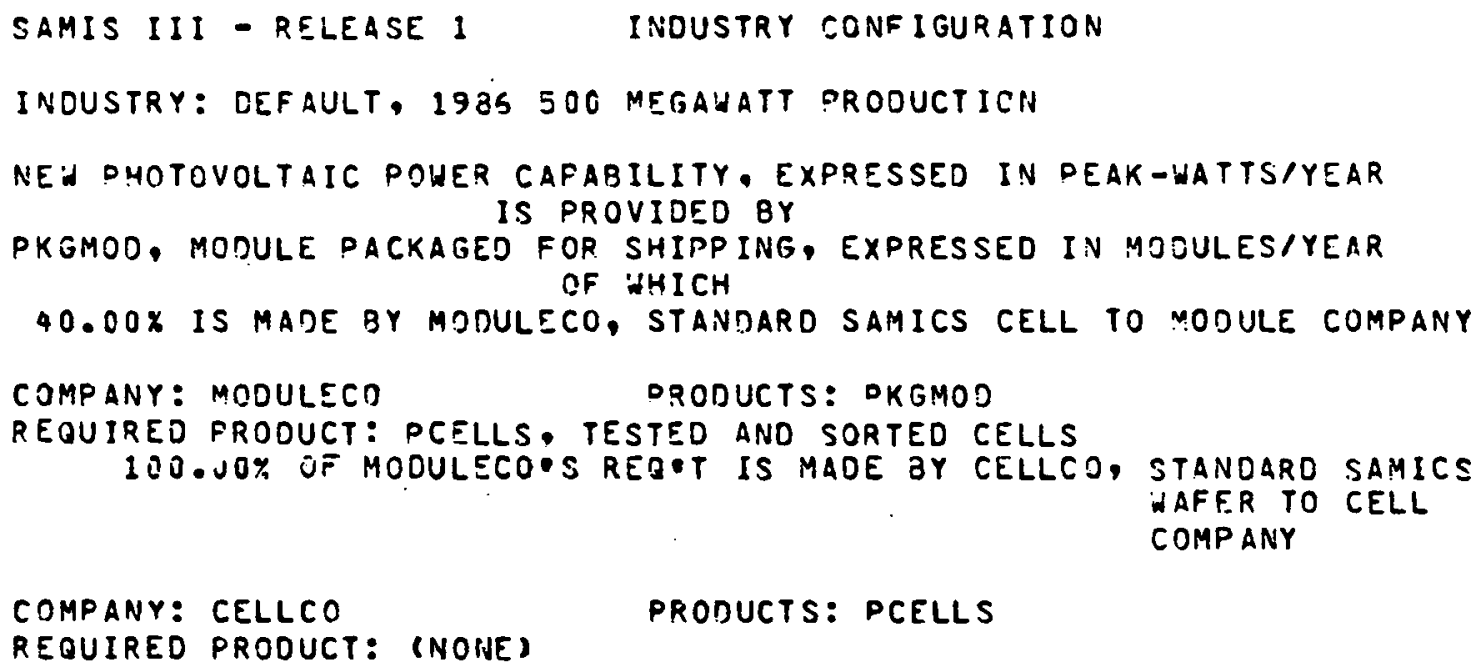

PRODUCTS: PCELLS 


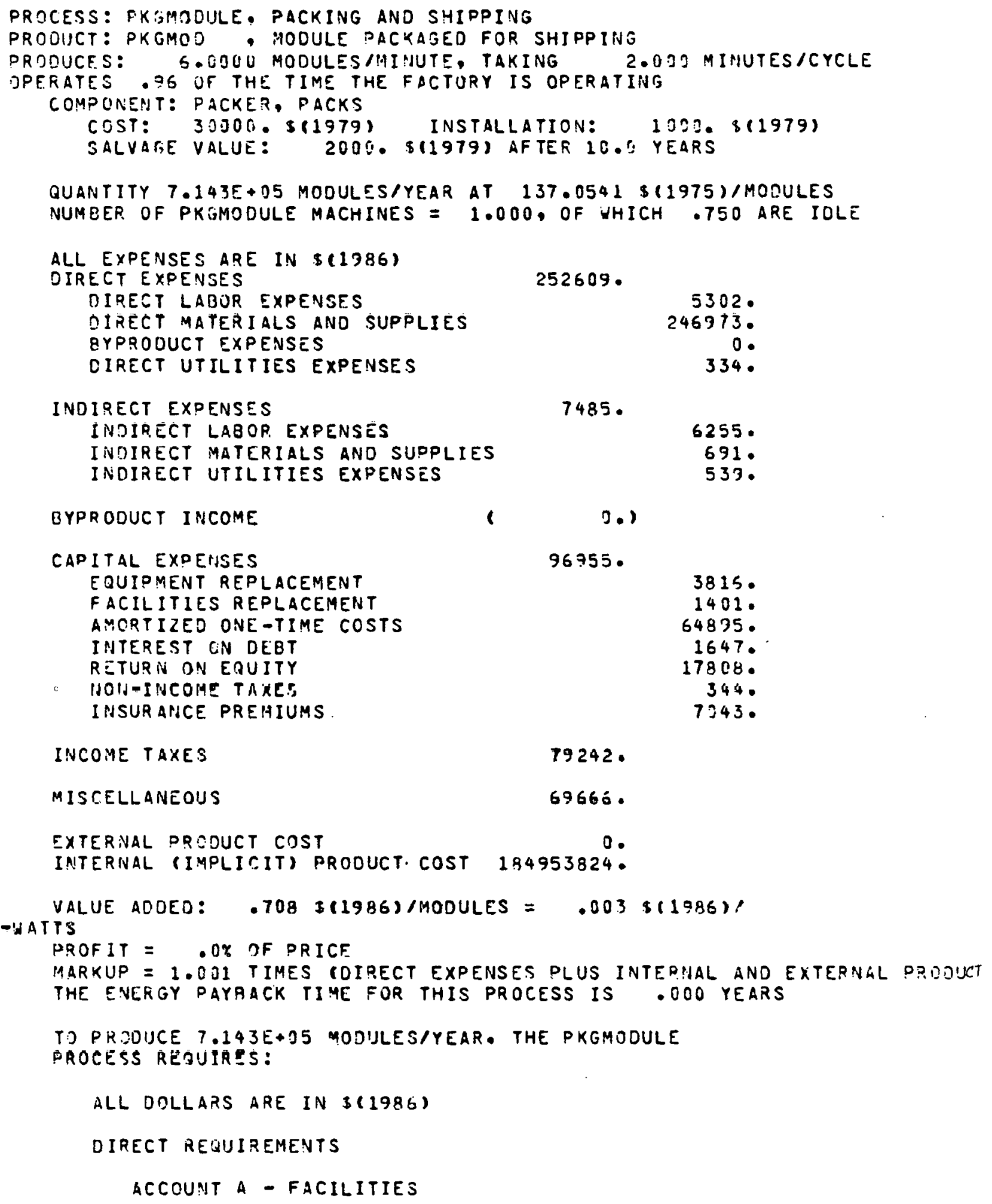




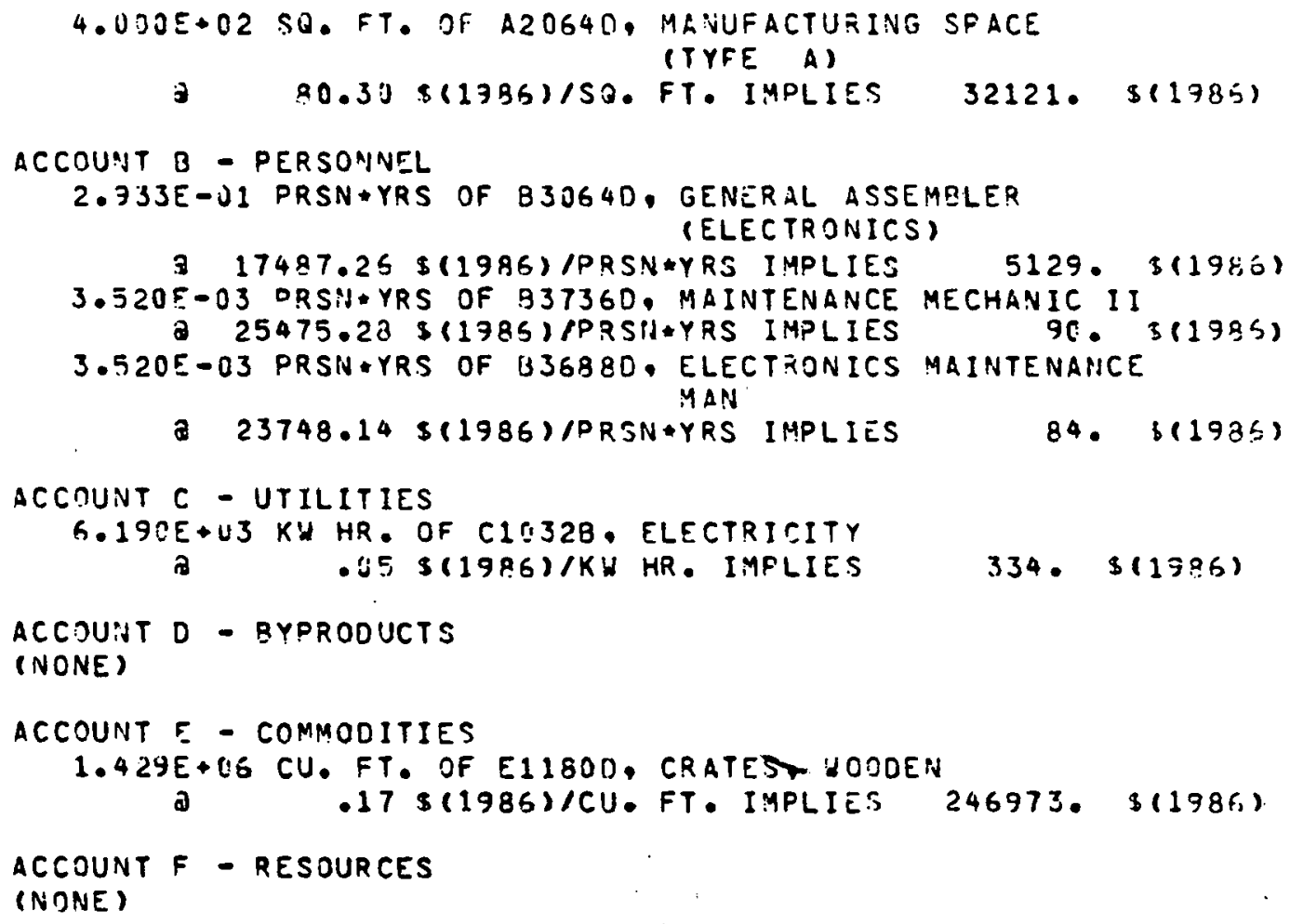




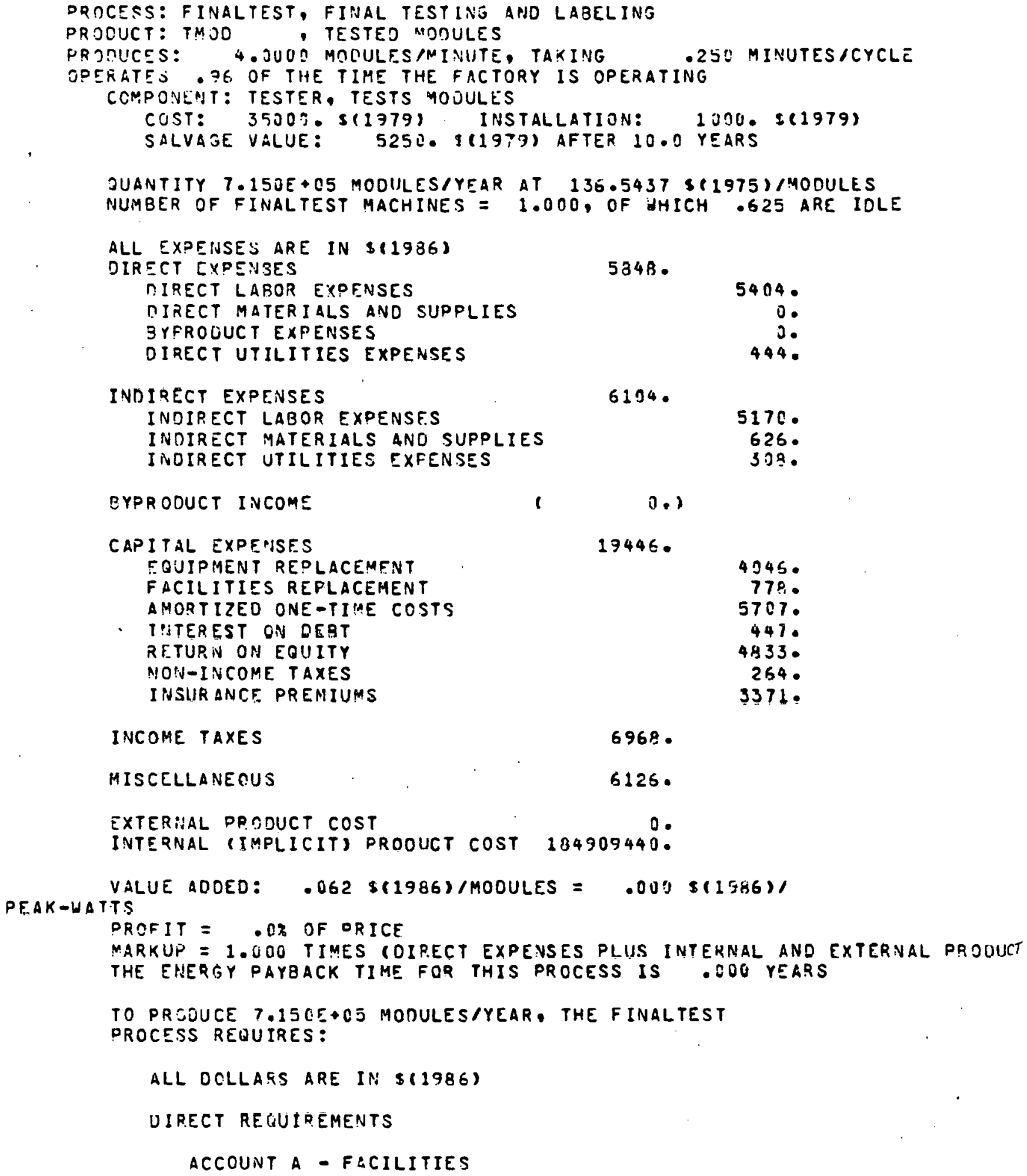




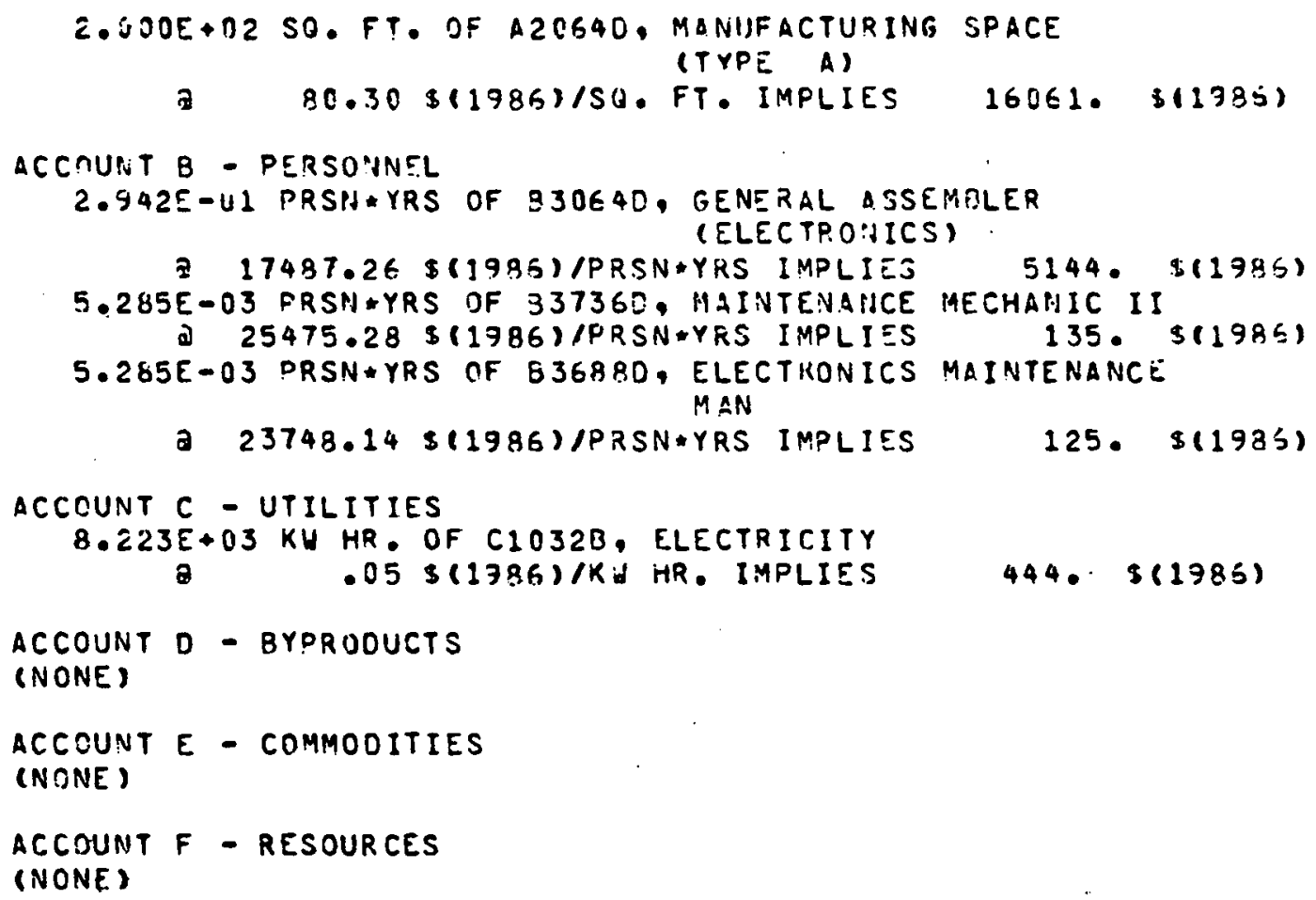




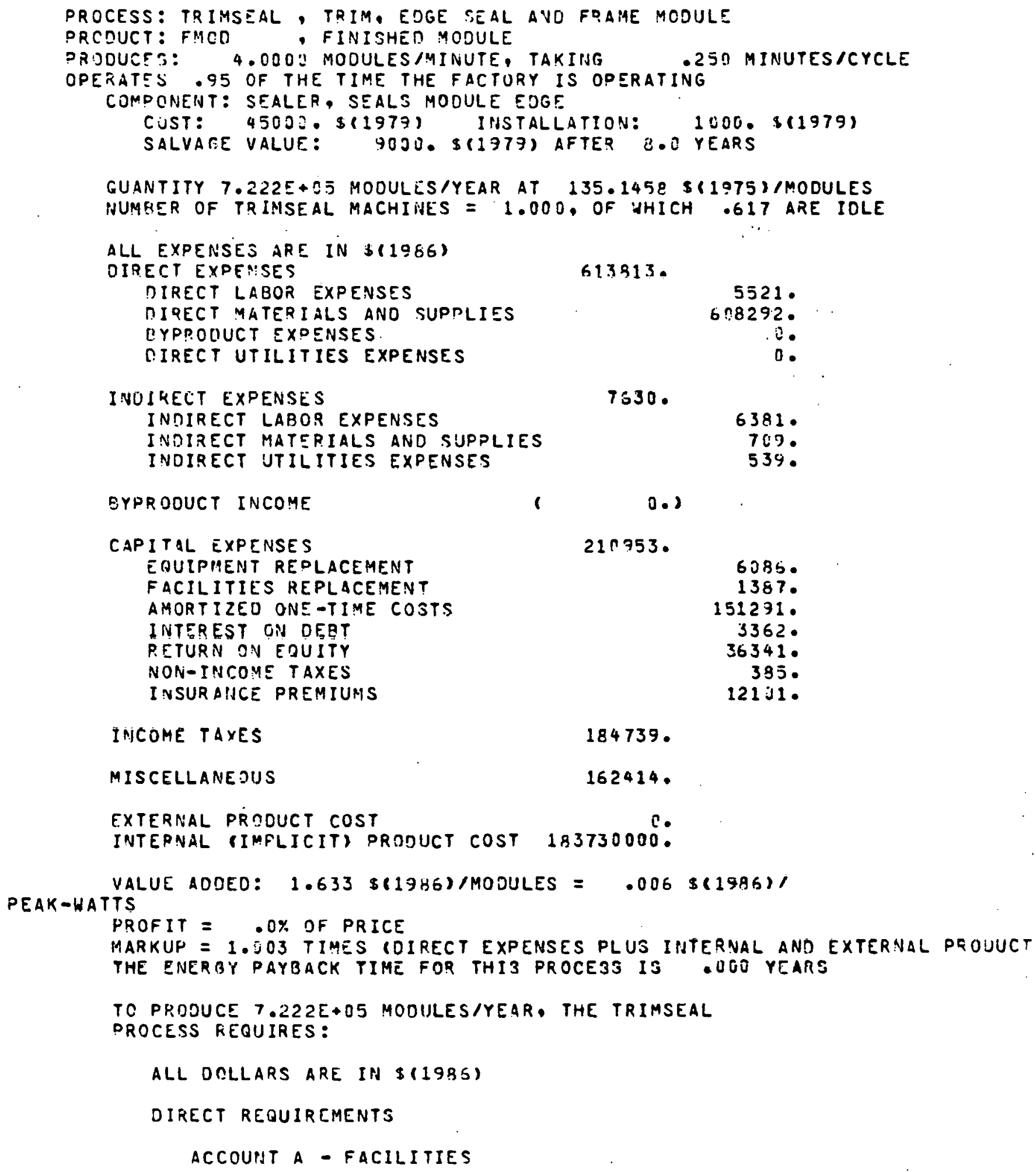




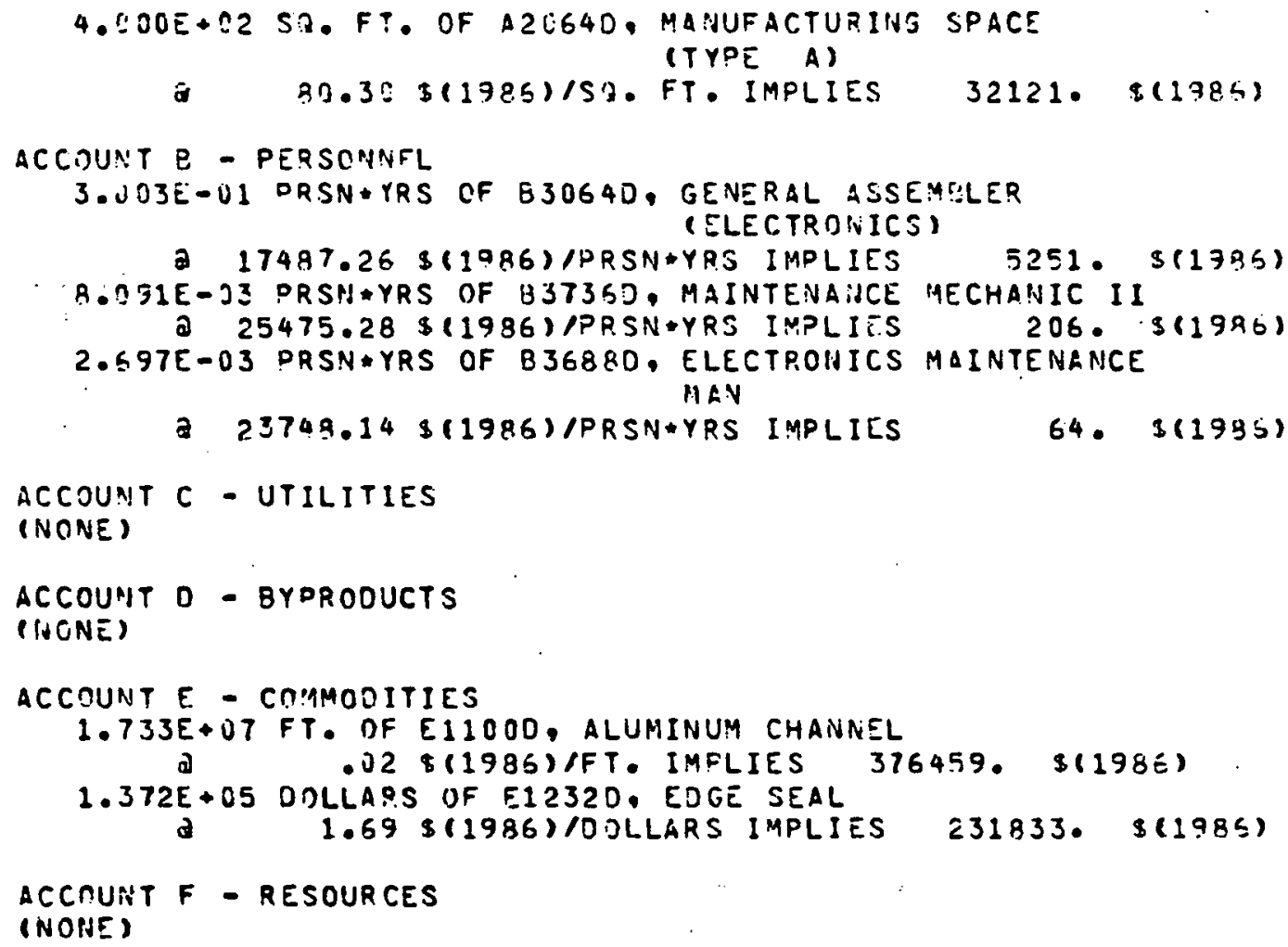




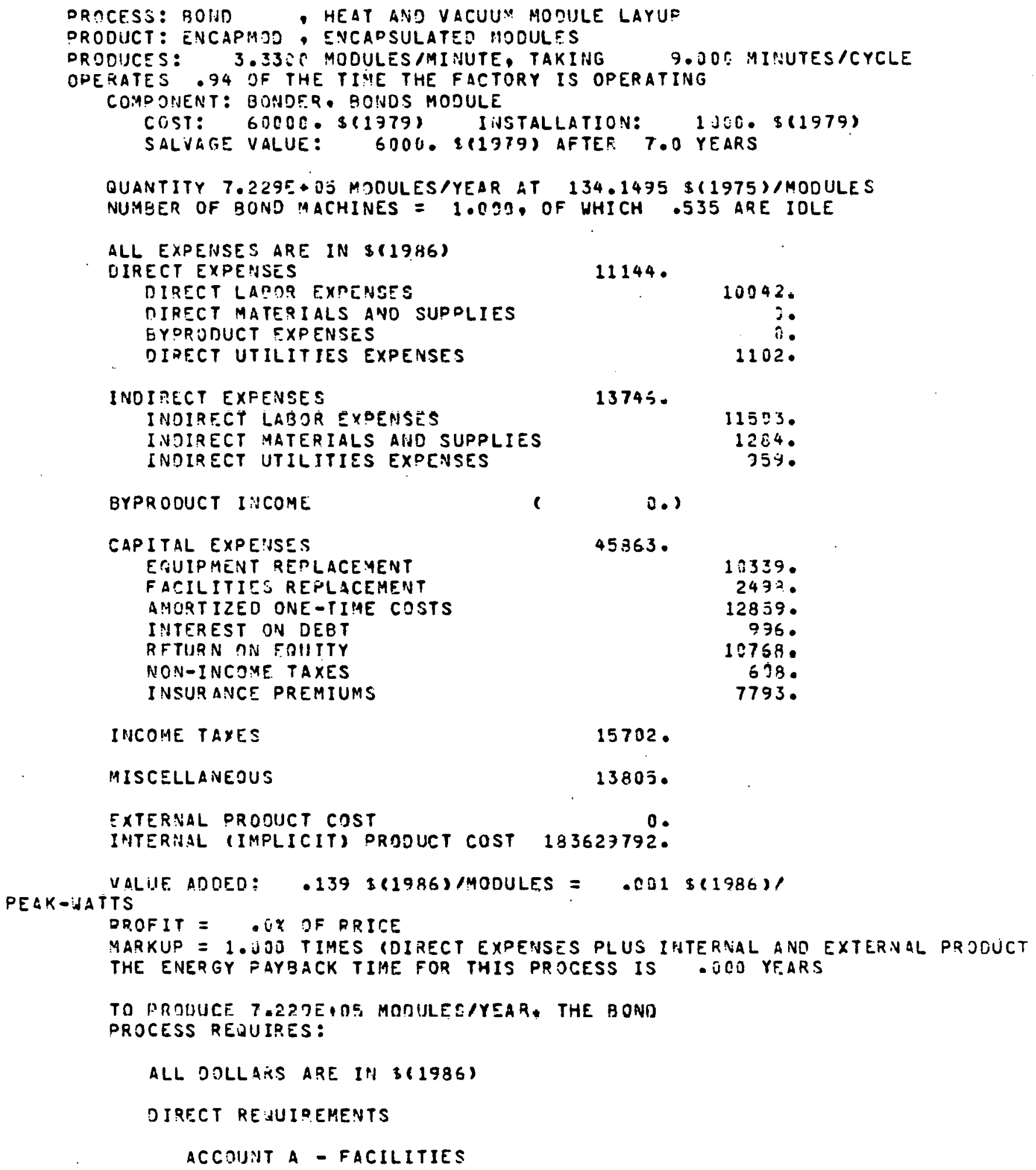




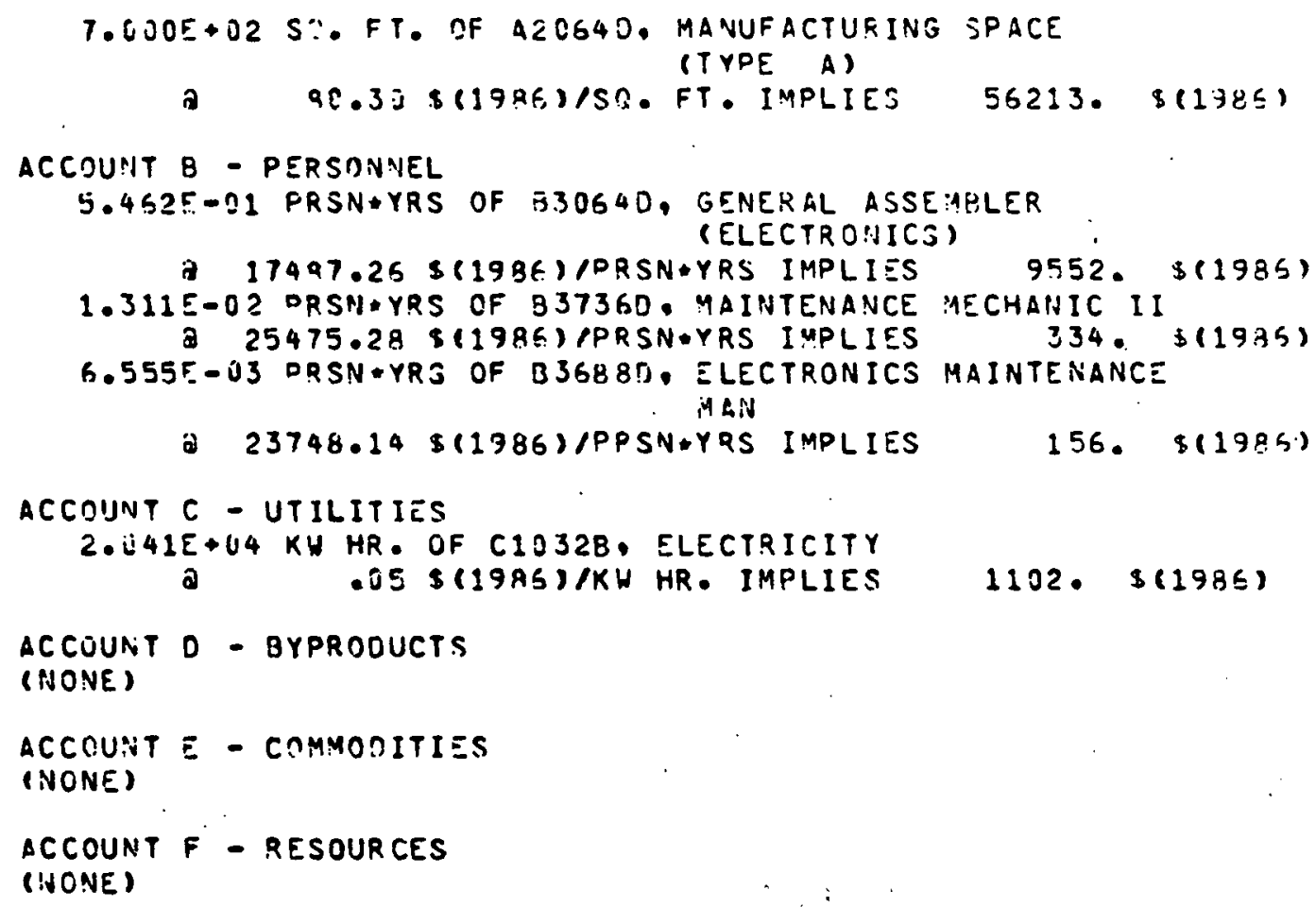




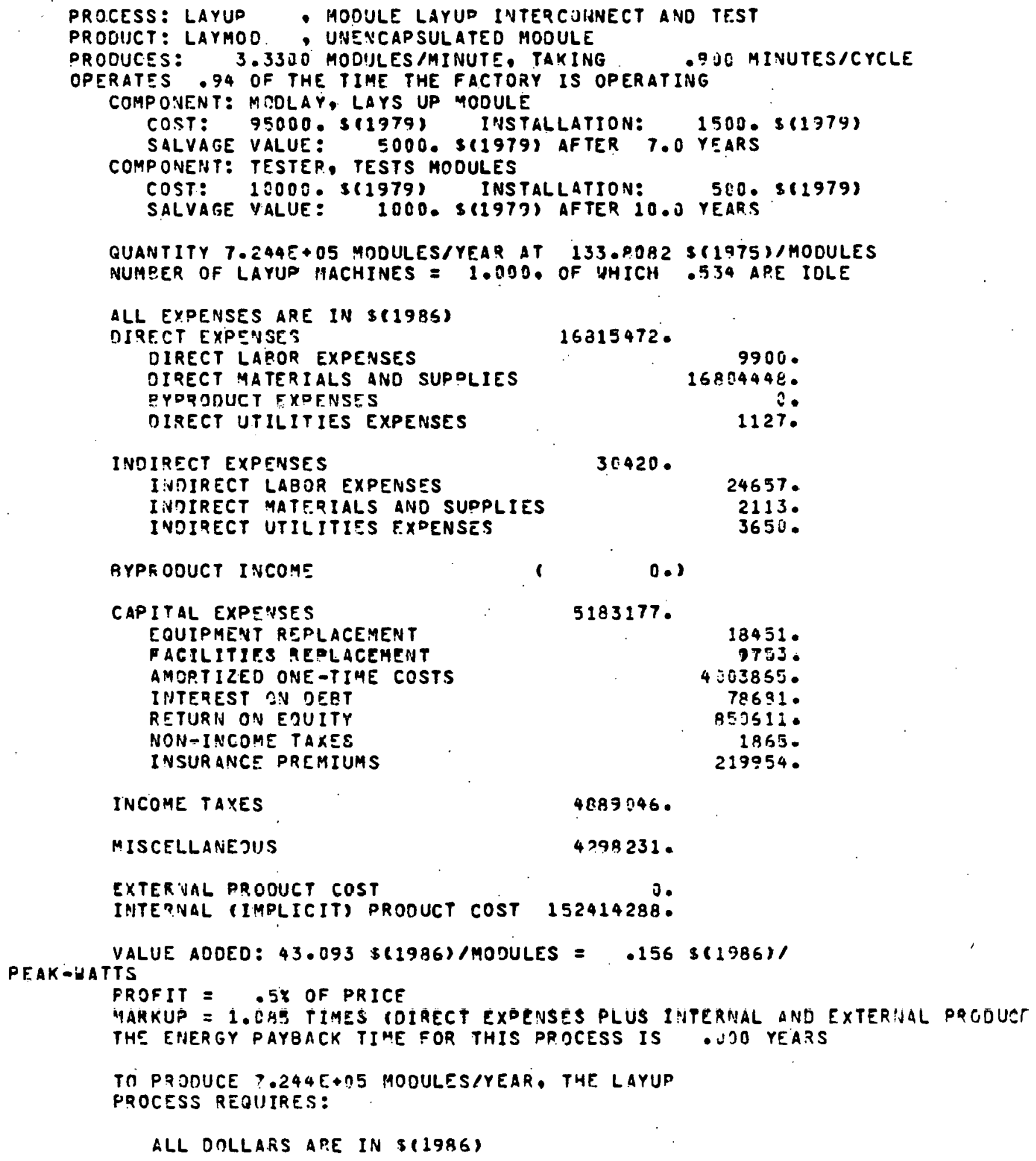




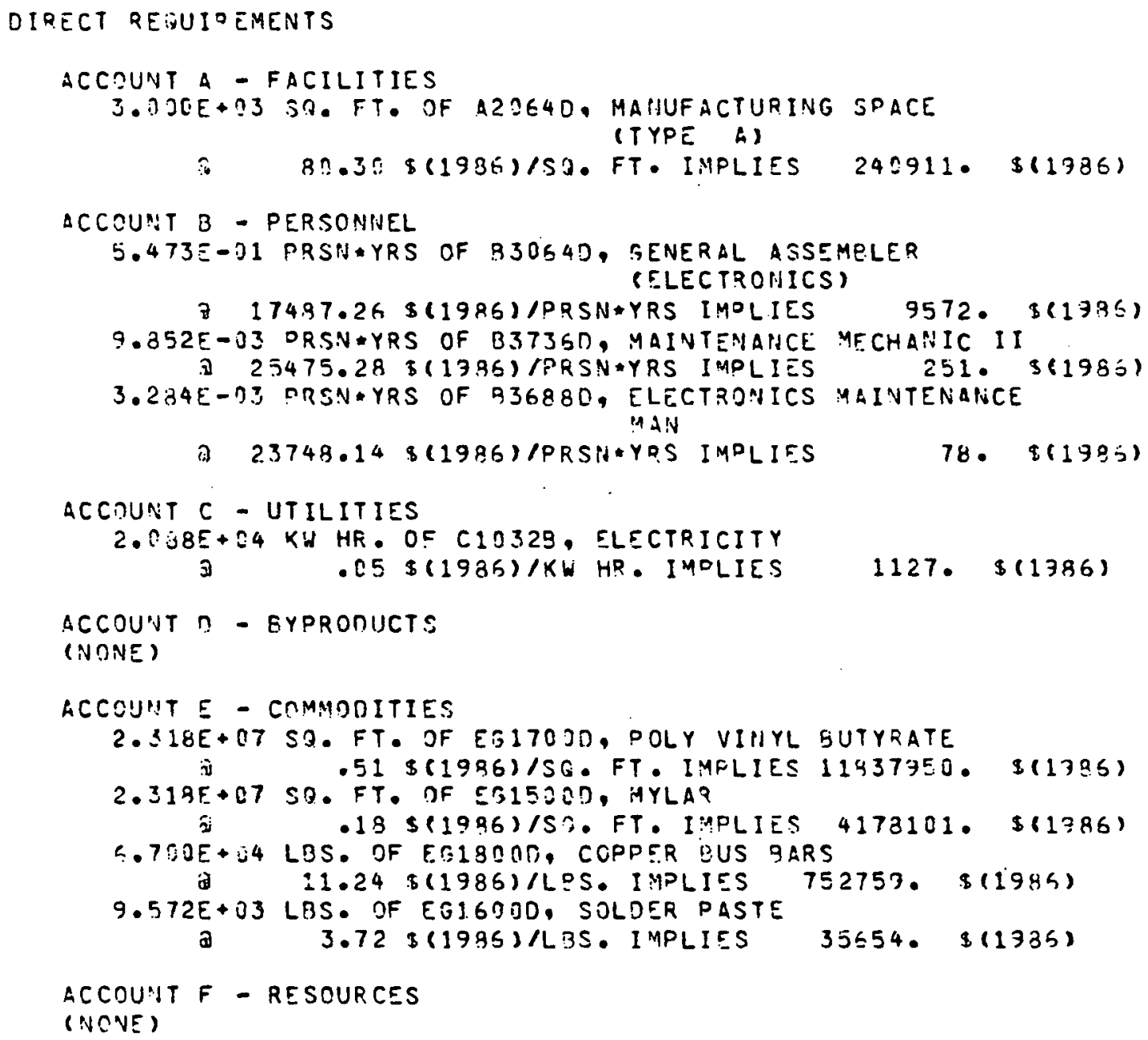




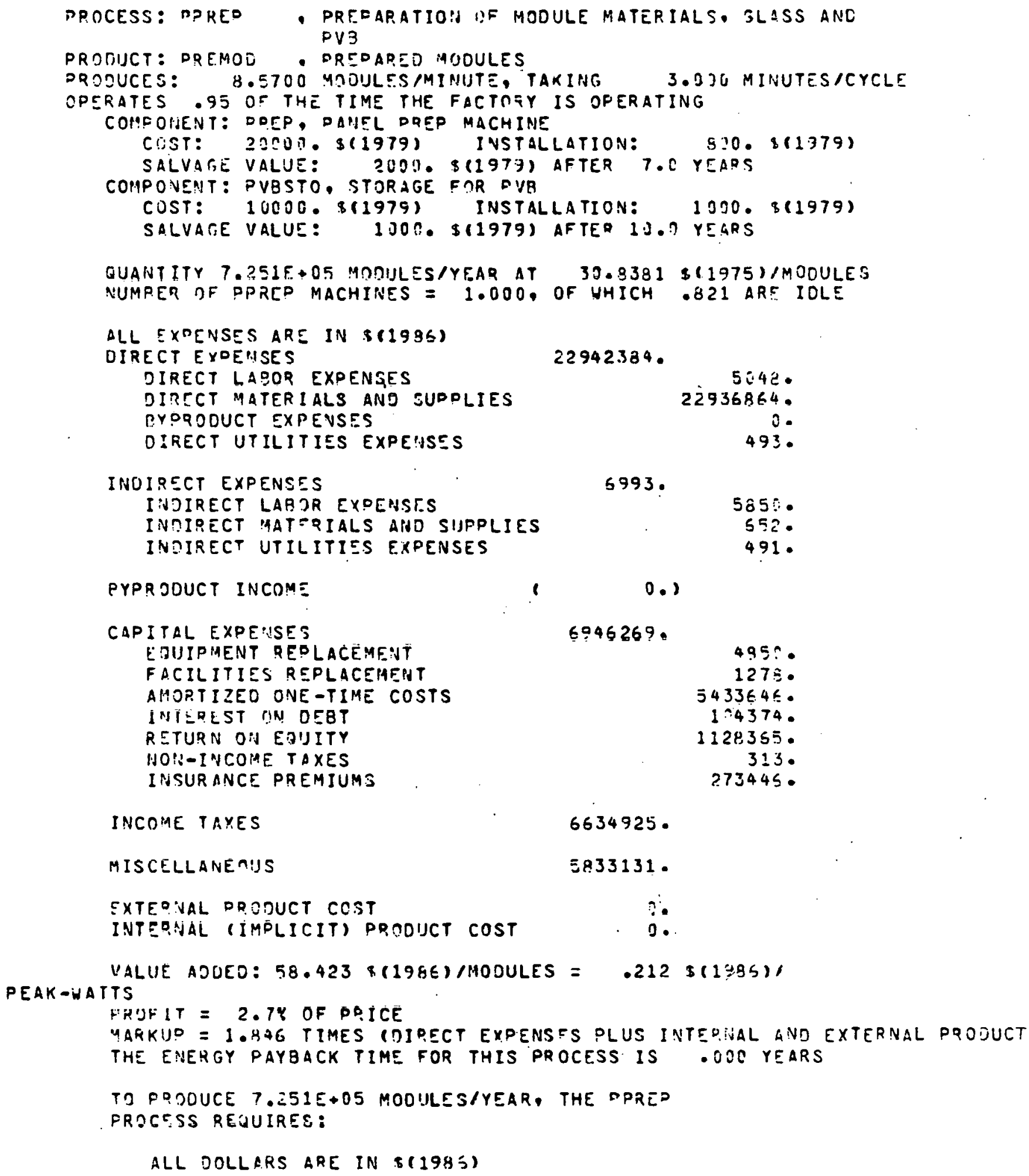




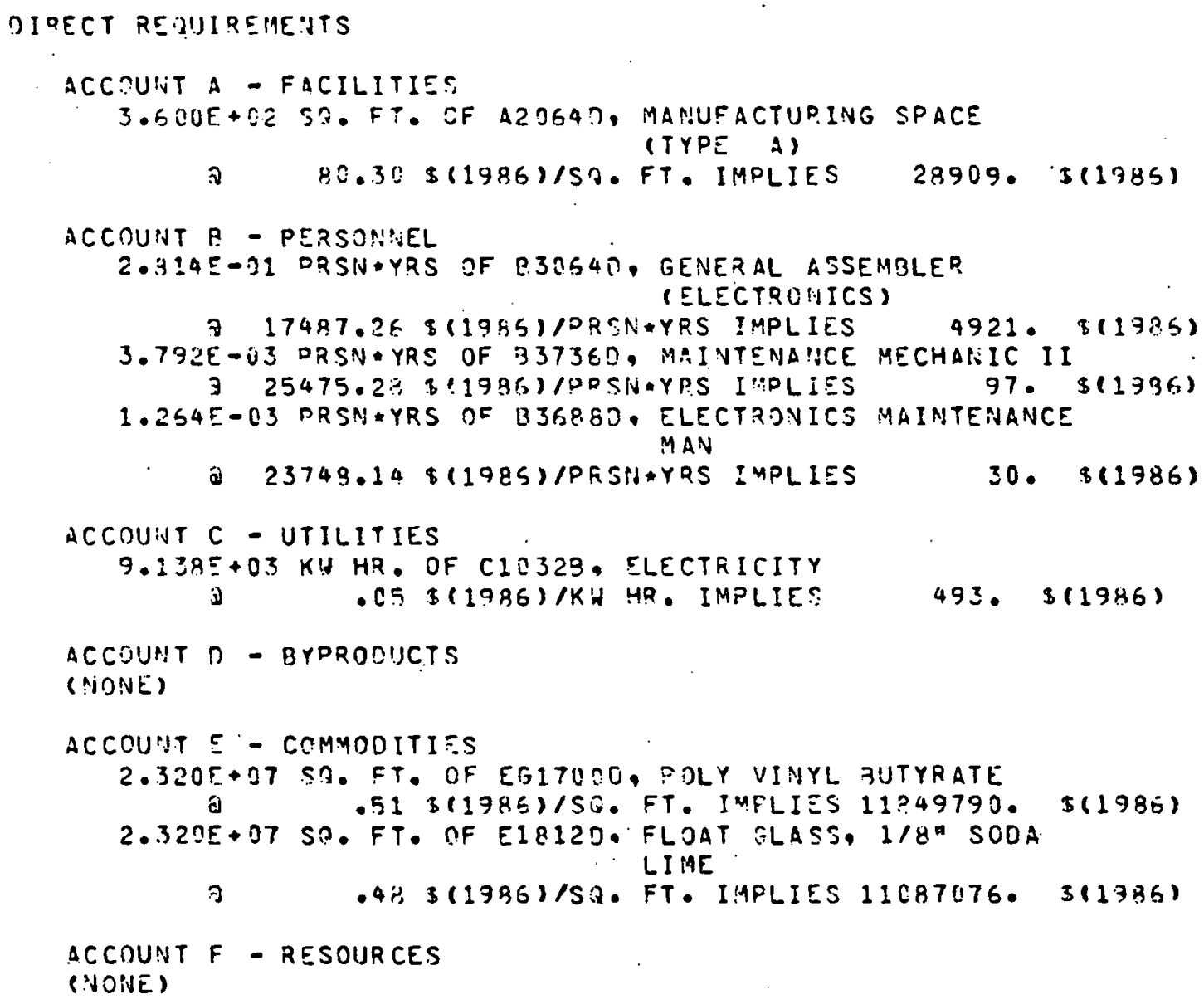




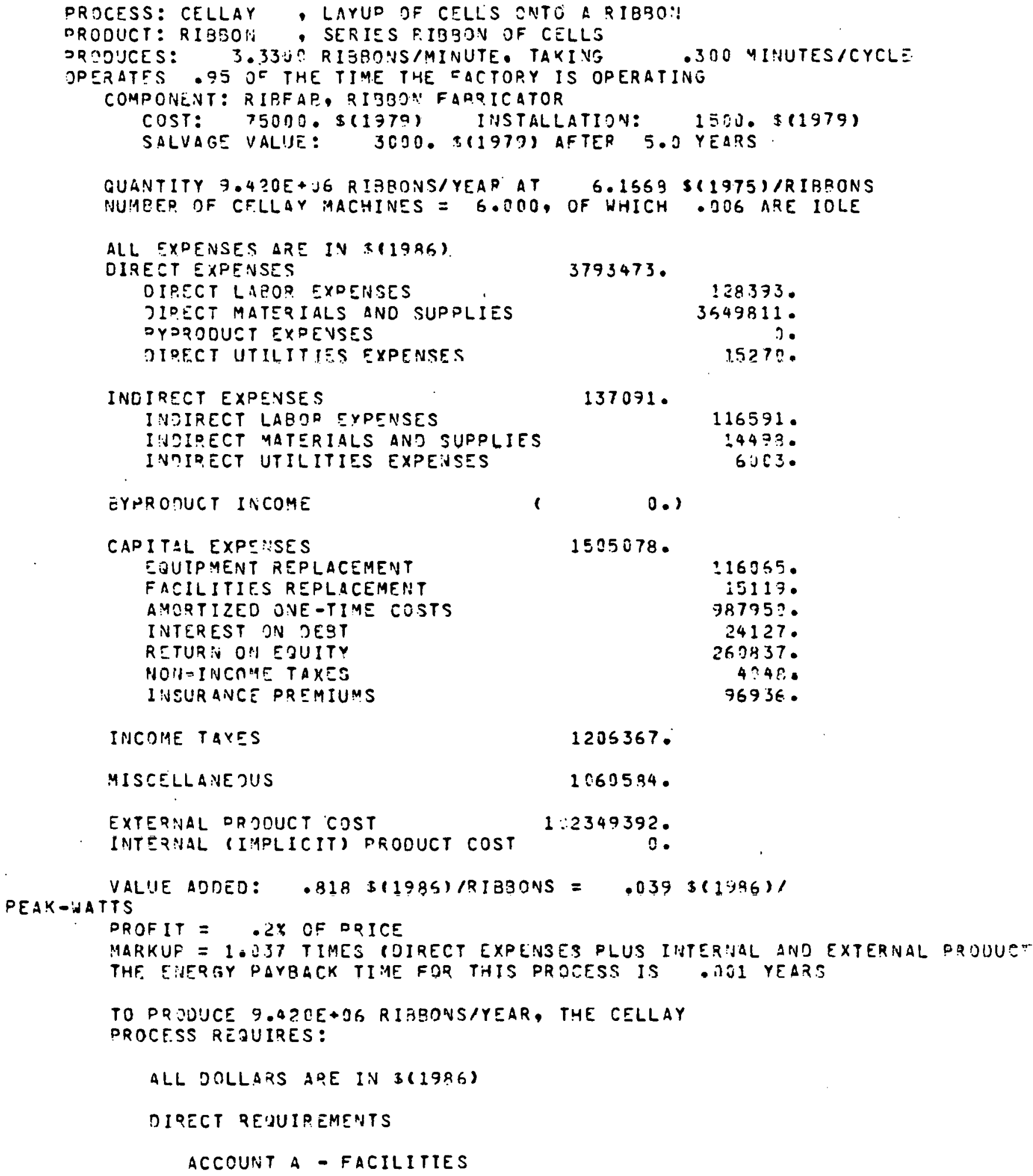




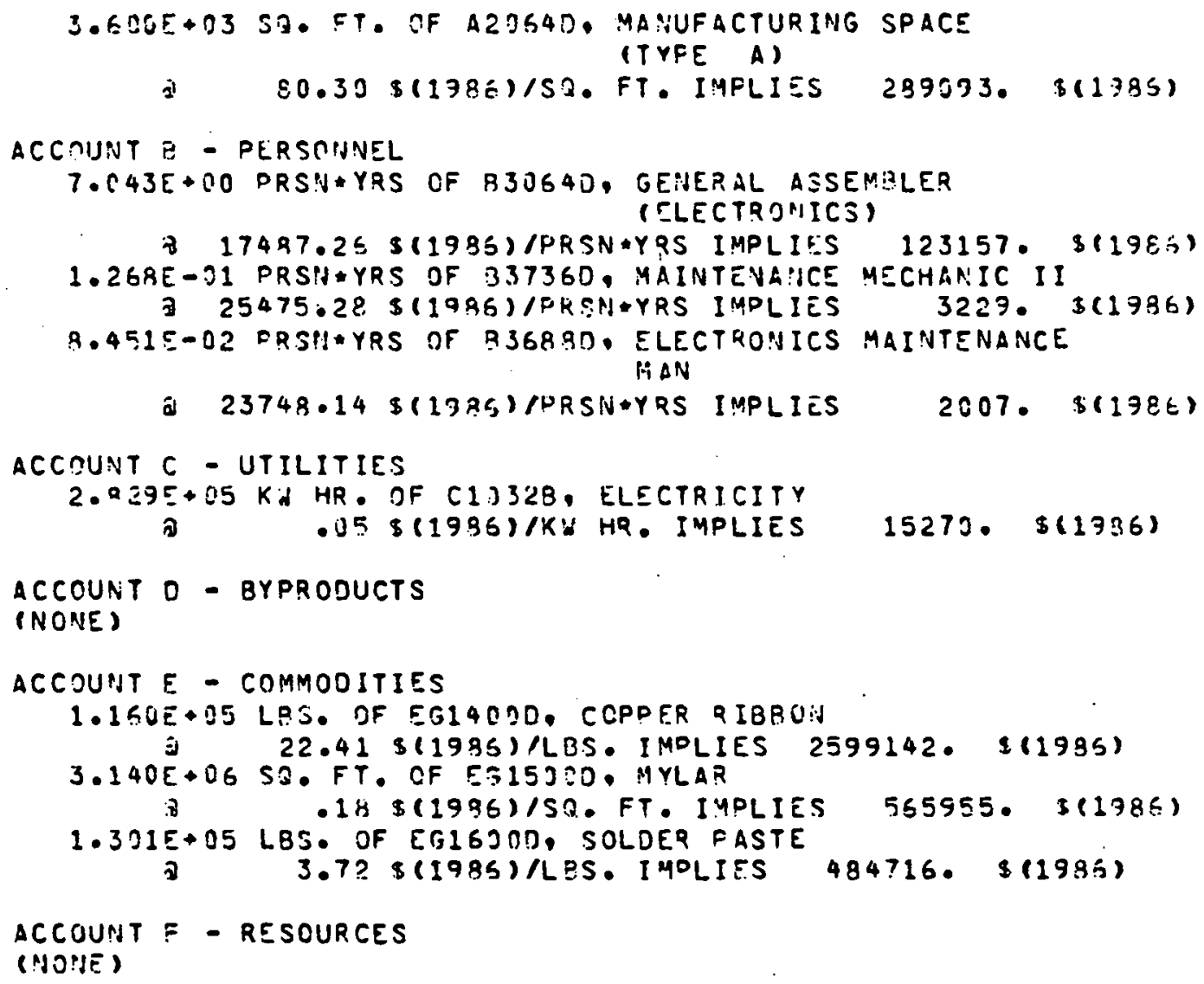


COMPANY: CELLCO, STANOARD SAMICS JAFER TO CELL COMPANY PROOUCTS: PEELLS

DUAVTITY: $2, \cap 75 E+U B$

PRICE:

$$
.26 \text { ? }
$$

$\$(1975) /$

CELLS

F.NERGY PAYBACK TIME = 021 YEARS

COMPANY MAPKUP $=1.3 E 1$ TIMES (DIRECT EXPENSES PLUS EXTERNAL PRCDUCT COSTS) COMPANY PROFIT $=1.5 \%$ OF PRICE

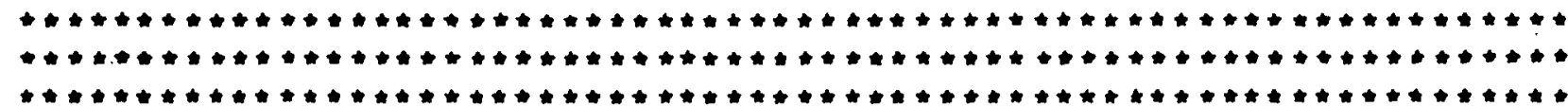




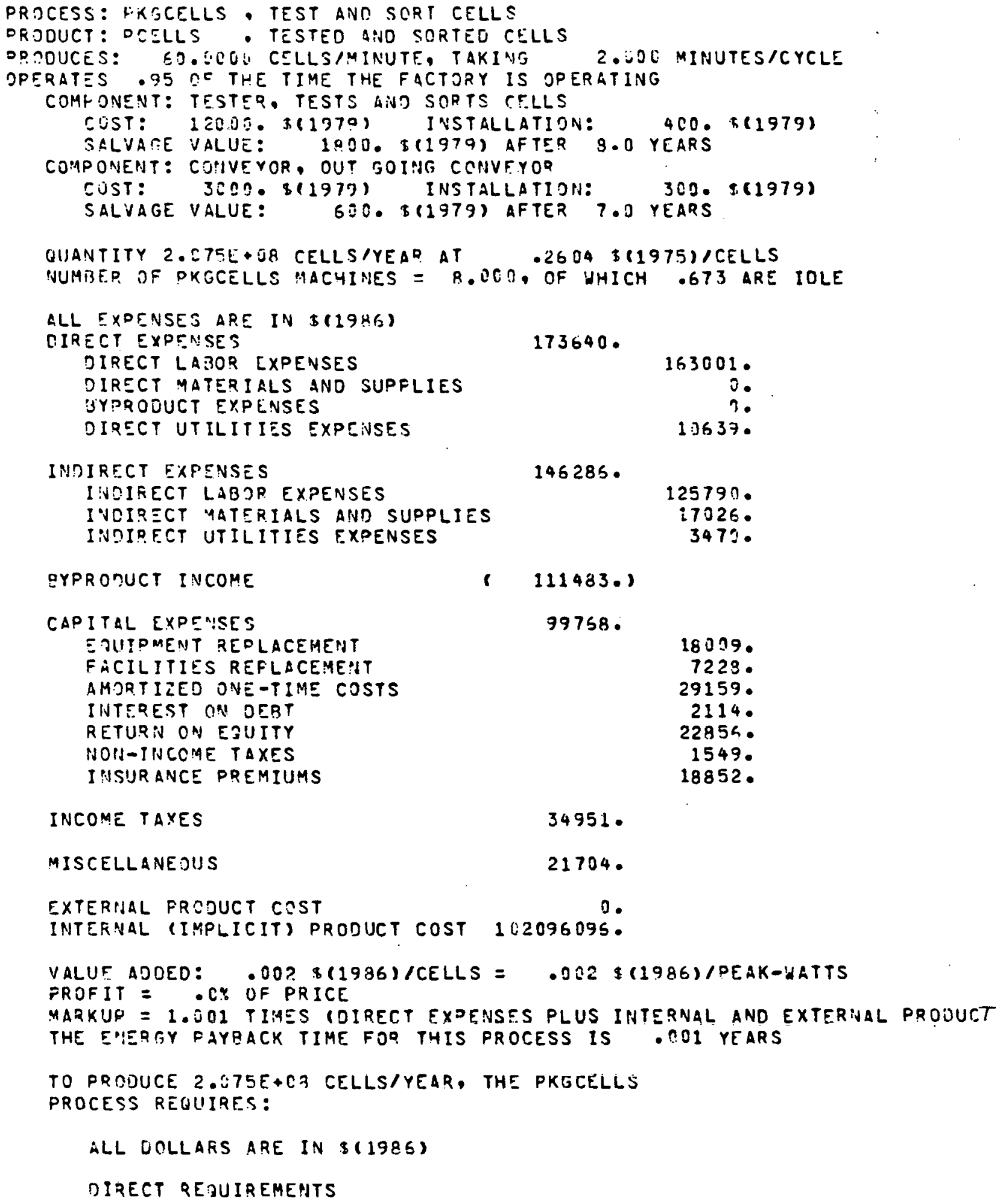




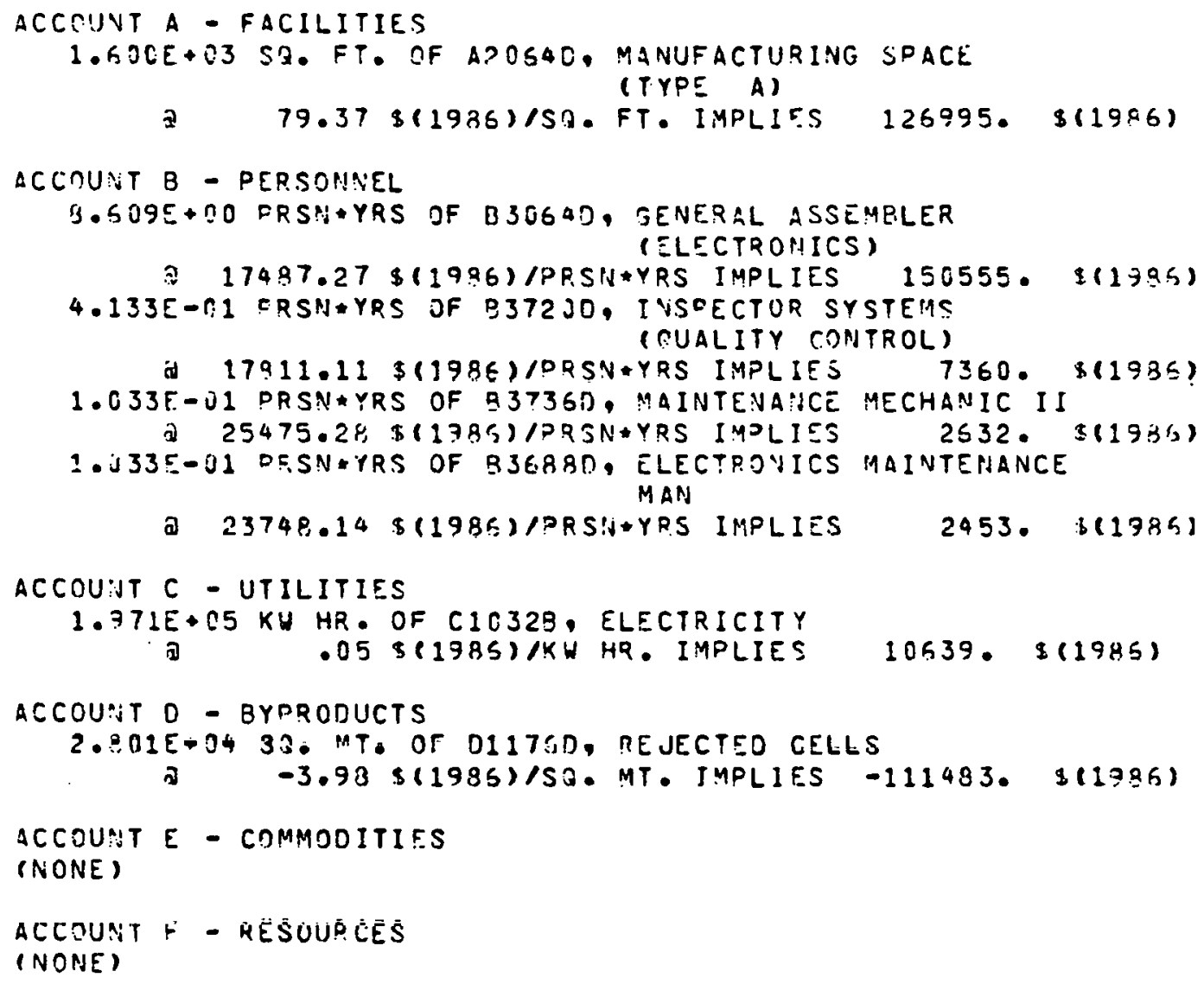




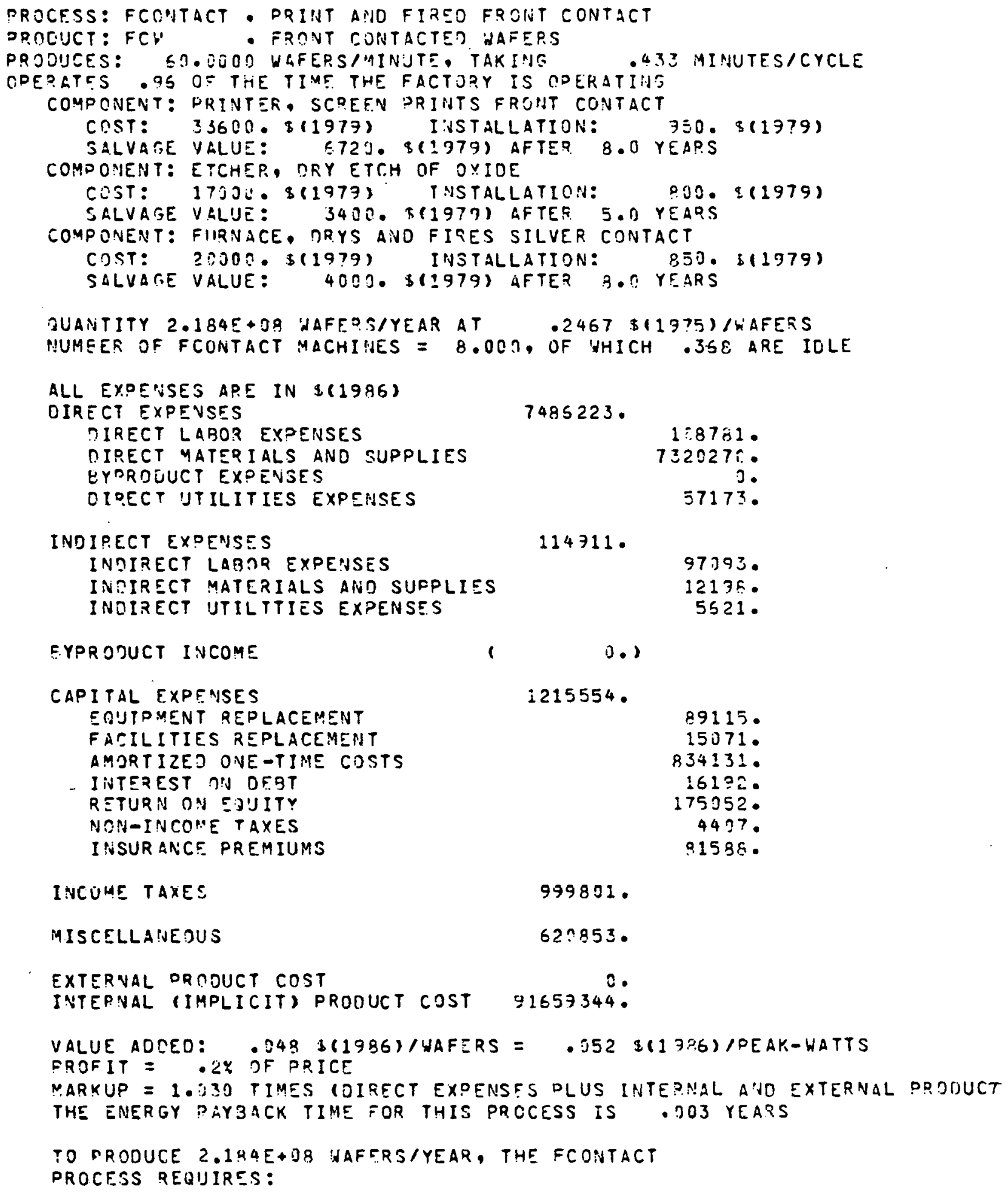

INCUHE TAXES

999851.

MISCELLANEOUS

$62 \div 953$

EXTERVAL DROOUCT COST

INTEPNAL (IMPLICIT) PROOUCT COST 91657344.

VALUE ADCED: .243 \$(1986)/WAFERS $=.052 \$(1396) / P E A K-W A T T S$ FROFIT $=.2 X$ OF PRICE

MARKUP = $1 .: 30$ TIMES IOIRECT EXPENSES DLUS INTEPNAL AVD EXTERNAL PRODUCT THE ENERGY PAY3ACK TIME FOR THIS PRCCESS IS . DOS YEARS

TO NRODUCE 2.14AE+D8 NAFERS/YEAR, THE FCONTACT

PROCESS REQUIRES: 


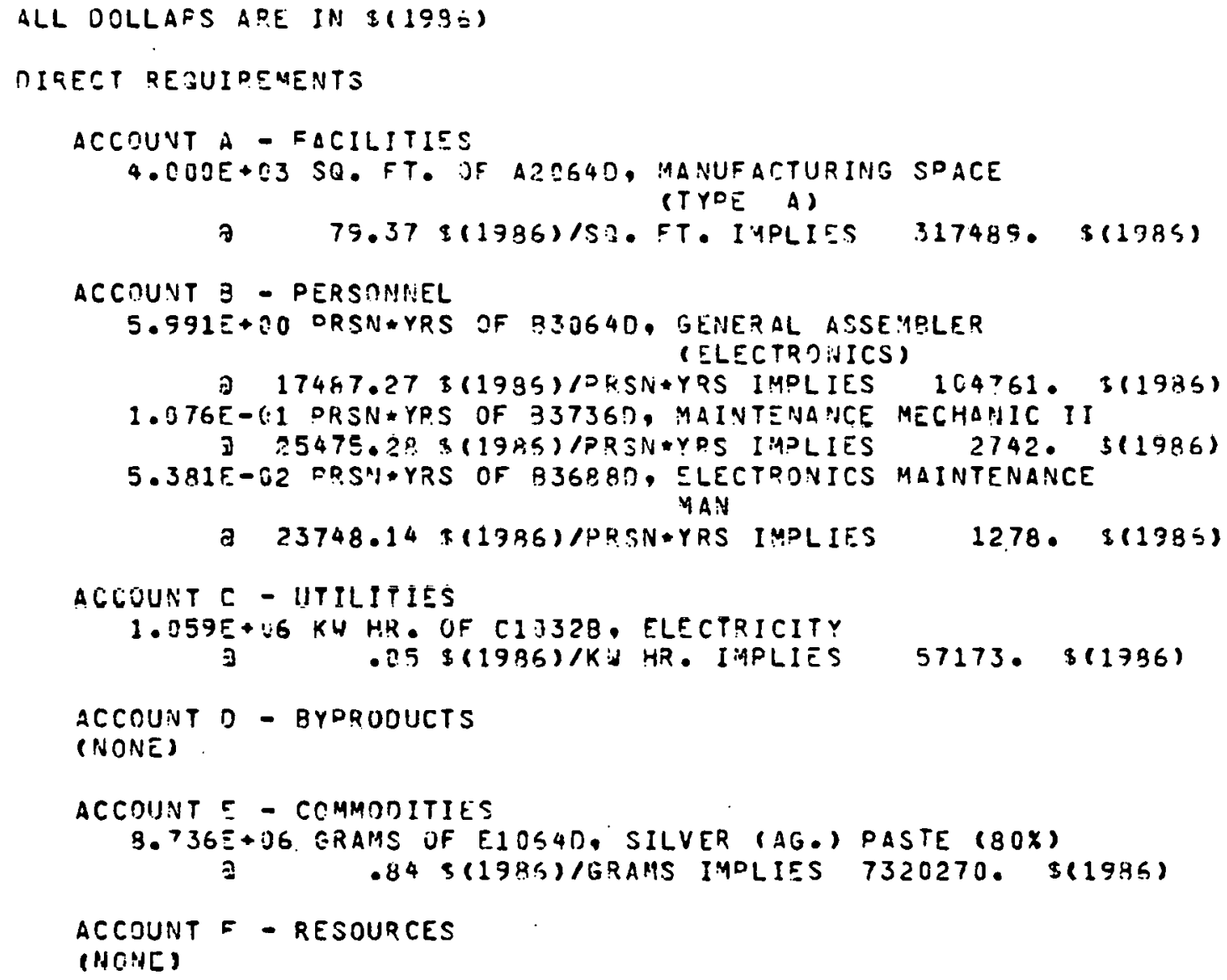




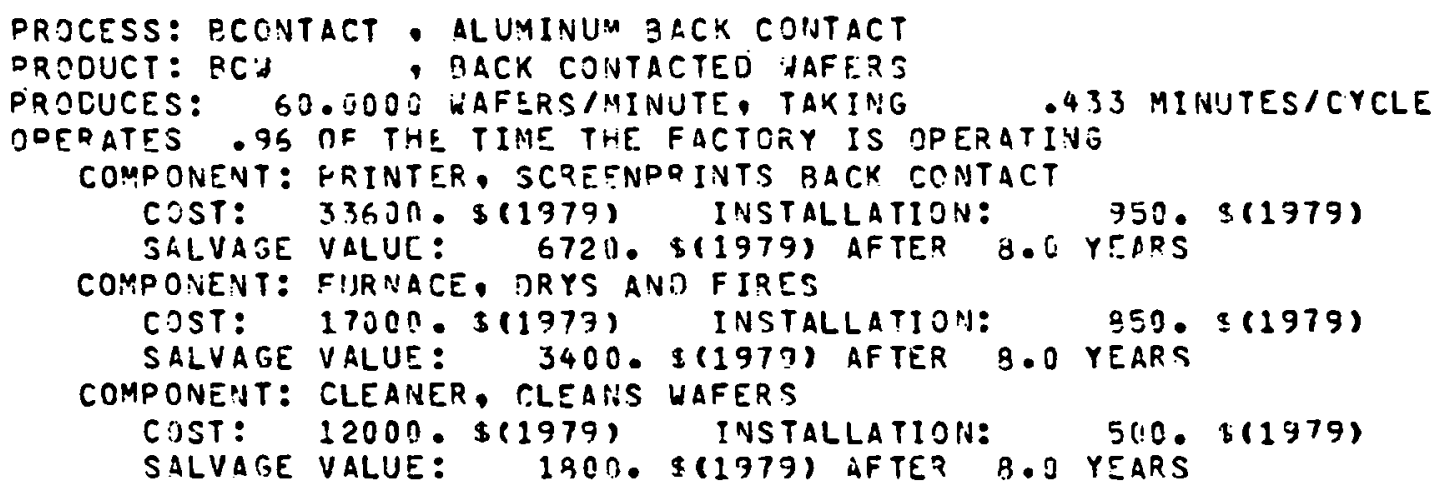

(

0.)

CAPITAL EXPENSES

F. IUIDMENT REDLACEMENT

FACILITIES REPLACEMENT

AMITTIZED ONE -TIME COSTS

INTEREST ON DERT

RETURH ON EPUITY

NOH-INCOME TAXES

INSUR ANCE PREMIUAS

$$
\begin{array}{r}
69719 . \\
14565 \\
171934 . \\
7312 . \\
79245 . \\
4194 . \\
55372 .
\end{array}
$$

INCOME TAXES

$2: 5963$

MISCELLANEOIIS

127898

EXTERNAL PRODUCT COST

INTERNAL (IMPLICIT) PRODUCT COST 99509392.

VALUE AODED: .010 \$(1986)/WAFERS = .011 \$(1386)/PEAK-WATTS

PRJFIT $=$ - I* OF PRICE

MARKUP $=1.093$ TIMES IOIPECT EXPENSES PLUS INTERIIAL AND EXTERNAL PRJUUCT THE FNERGY PAYBACK TIME FOR THIS PROCESS IS - JO3 YEARS

TO PROUUCE 2 .193E+D8 WAFERS/YEAR, THE BCONTACT

PROCESS REUUIRES: 


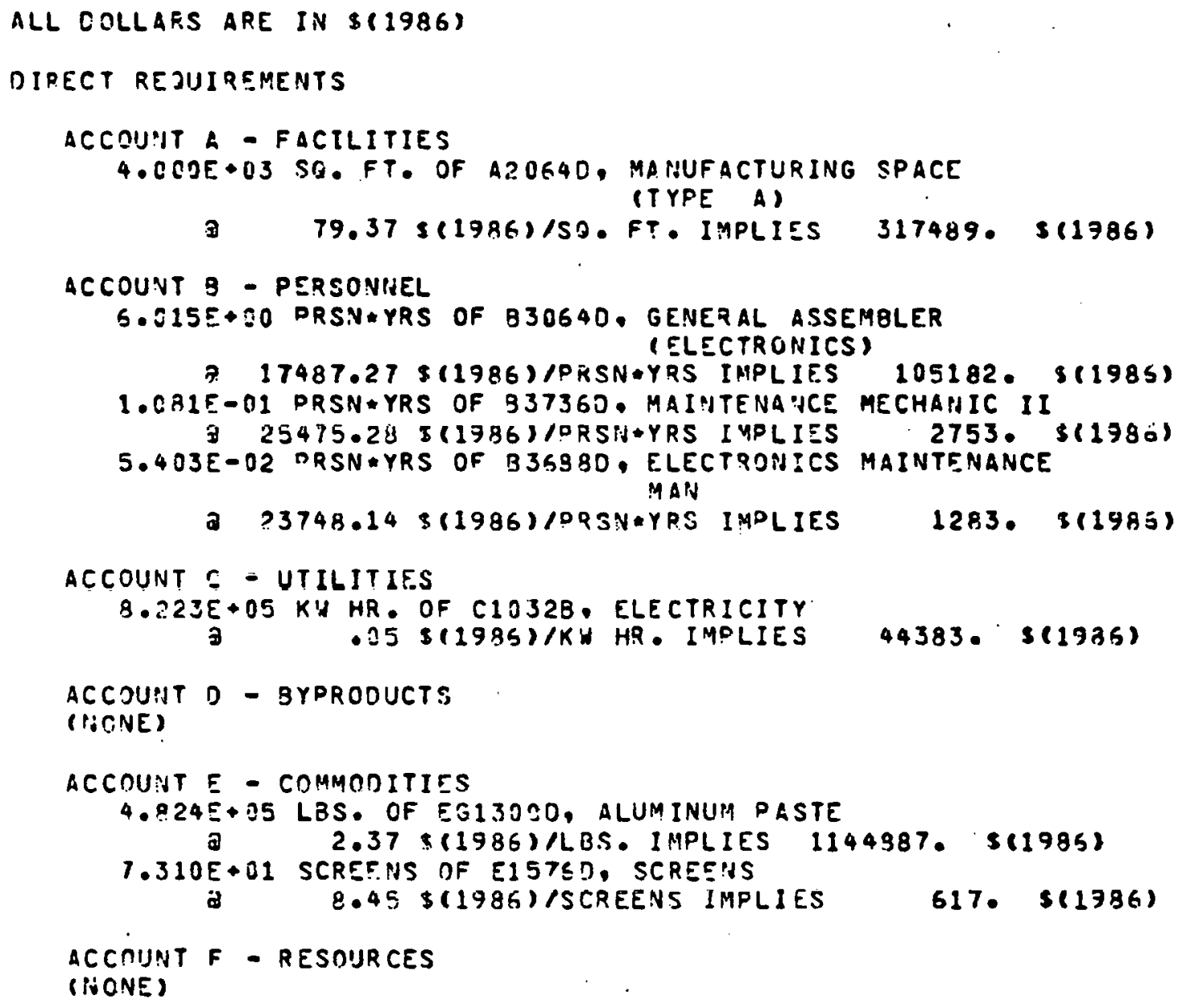




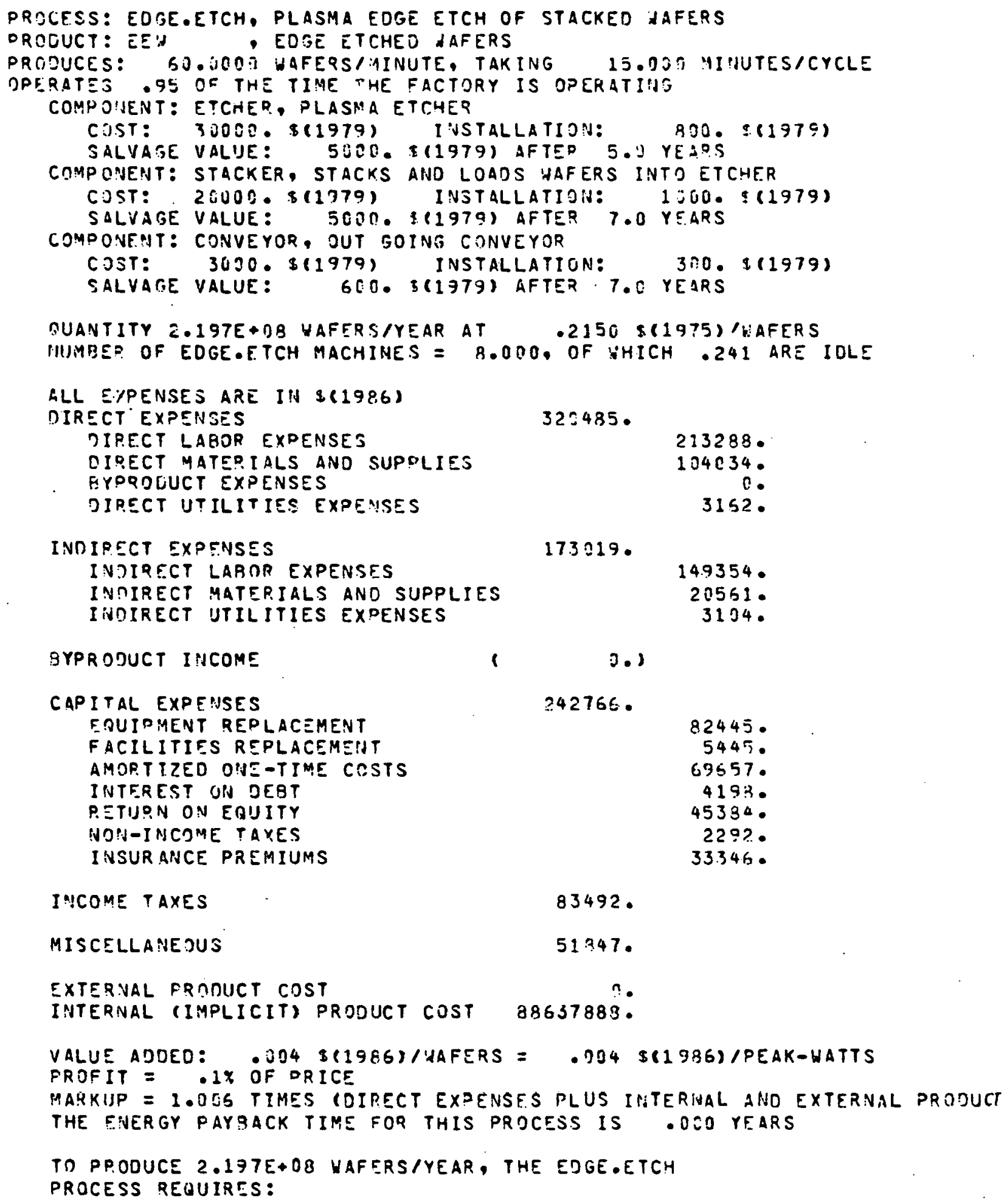




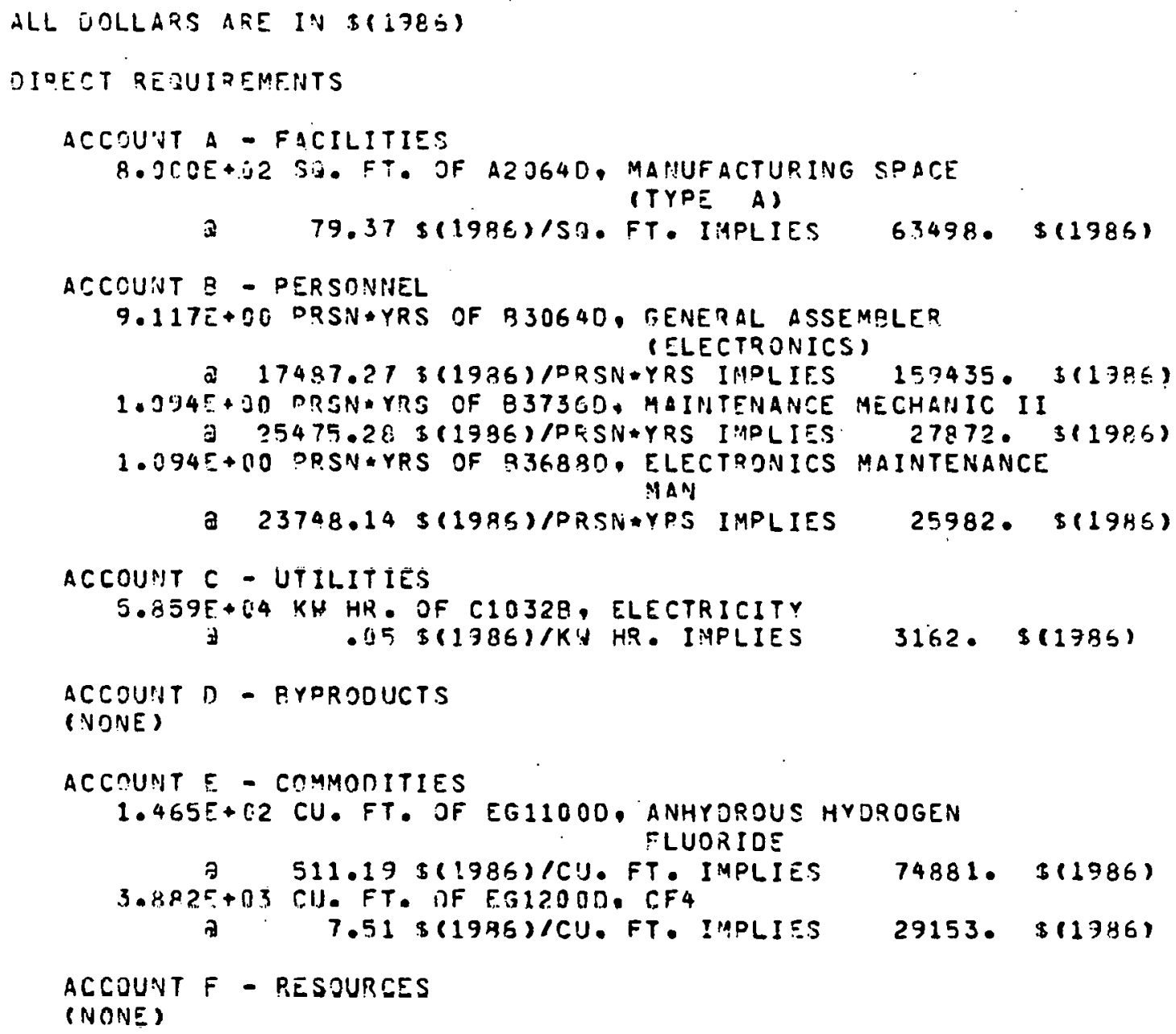


PROCESS: DIFFUSION, DOCL DIFFUSION FURPACE

DRCOUCT: OU DIFFUSEO NAFERS

PRODUCES: 71.1JOR HAFERSIMINUTE, TAKING 45.000 MINUTES/CYCLE

APEQATES .94 CE THE TIYE THE FECTORY IS OPERATING

COMPOINENT: FIJRNACE. DIFFIJSION FURNACE YITH PULLSPS

CUST: 112000.\$(1979) INSTALLATION: $1300 . \$ 11973)$

SALVATE YALIJE: 15800. $\$(1979)$ AFTER 7.0 YEARS

COMPONENT: LOAD. LOADS YAFERS INTO BOATS AND ONTO SLEDS

COST: 15J0U. \$(1979) INSTALLATION: 8:0. 3(1979)

SALVAGE VALUE: 24IC. $3(1979)$ AFTER 7.0 YEARS

COMPO:JENT: CONVEYOR, OUT GOING CONYEYJP.

COST: 3.00. $(1979)$ INSTALLATION: 300. $\$(1979)$

SALVARE VALUE: 600. \$(1973) AFTER 7.0 YEARS

OUAHTITY 2.222T+OR WAFEPS/YEAR AT -21R6 \&(1775)/IAFERS

NUMBER OF DIFFUSION MACHINES $=7.300$. OF UHICH . $30 \%$ ARE IDLE

GLL EXPENSES ARE IN S(1986)

DIRECT EXPENSES

DIPEET LABOZ EXPENSES

OIRECT MATERIALS ANU SUPPLIES

PYPR SOUCT EXPENSES

DIPECT UTILITIES EXPENSES

494323

142132
162214
0
190579

INDIRECT EXPENSES

INOIRECT LABOR EXPENSFS

INIIRECT MATERIALS ANO SUPPLIES

INDIRECT UTILITIES EXPEASES

139456.

118751
15427
5276

Q.)

533171 .

$$
\begin{array}{r}
149475 . \\
23433 \\
112196 \\
11354 \\
122359 . \\
7824 . \\
99025 .
\end{array}
$$

132858.

$82: 05$.

MISCELLANEDUS

EXTERTAL PRJDUCT COST

INTEPNAL (IMPLICIT) DRODUCT COST $\$ 7259408$.

VALUF ADDED: .DOS \$(1986)/WAFERS = .007\$(17RS)/DEAK-WATTS

PROFIT $=$ IX DF PRICE

MARKUP = 1.PIO TIMES PDIRECT EXPENSES PLUS INTERNAL AND EXTERNAL PROBUCT

THE ENERGY FAYSACK TIME FOR THIS PROCESS IS . JIO YEARS

TO DRODUCE $2.222 E+$ + NA YAFERS/YEAR, THE DTFFIJSION

FROCESS REQUTIRES: 


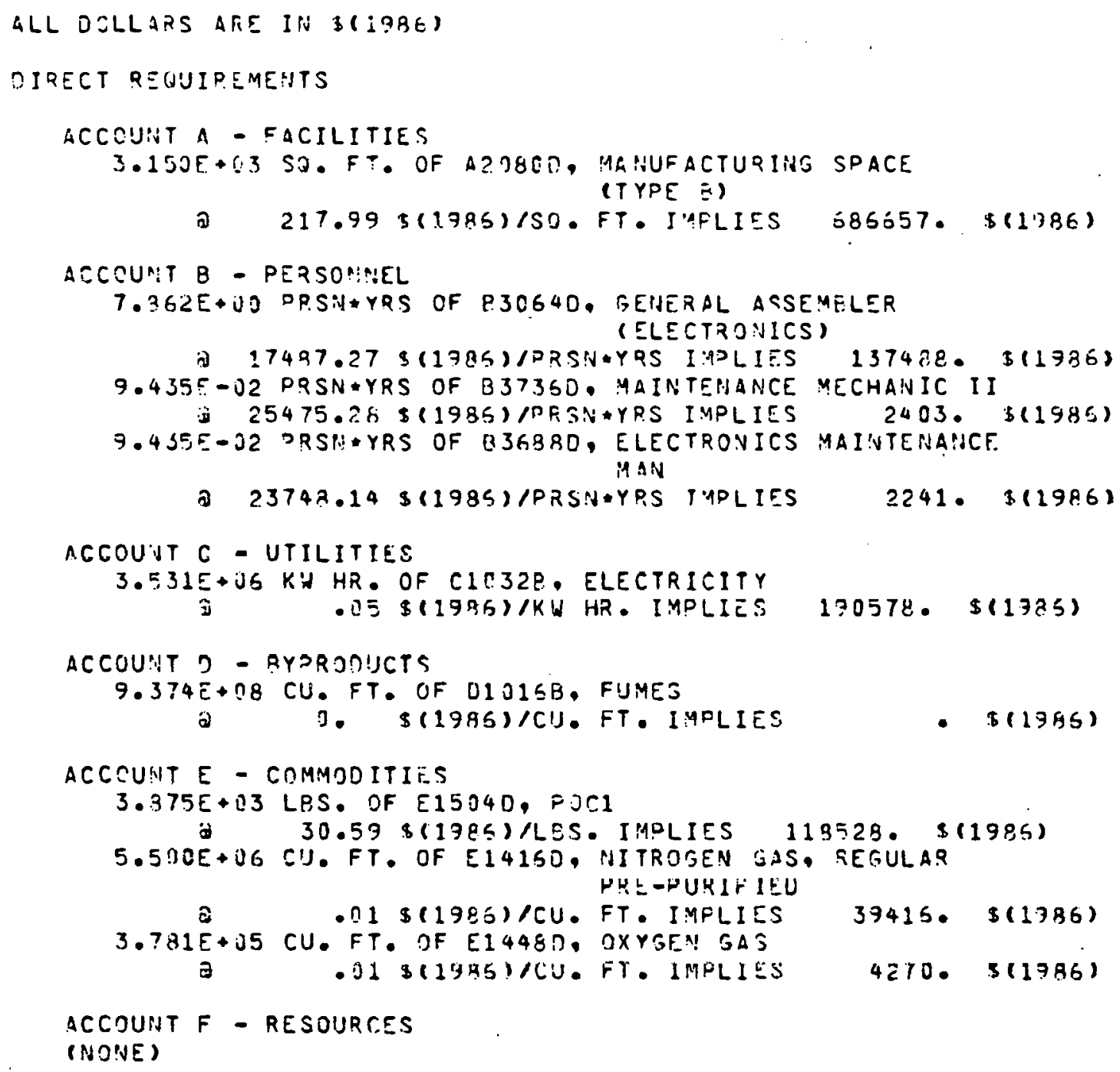




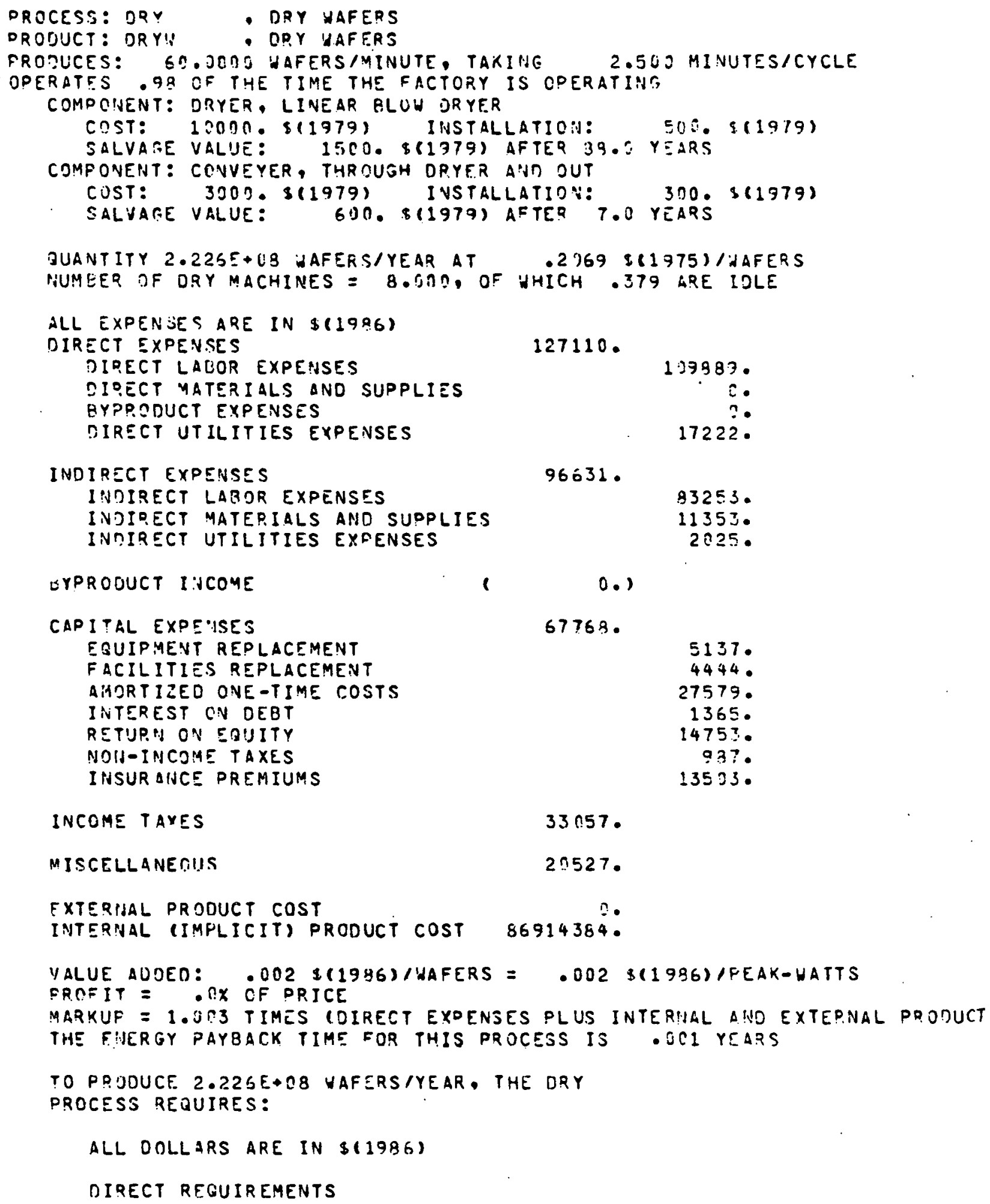




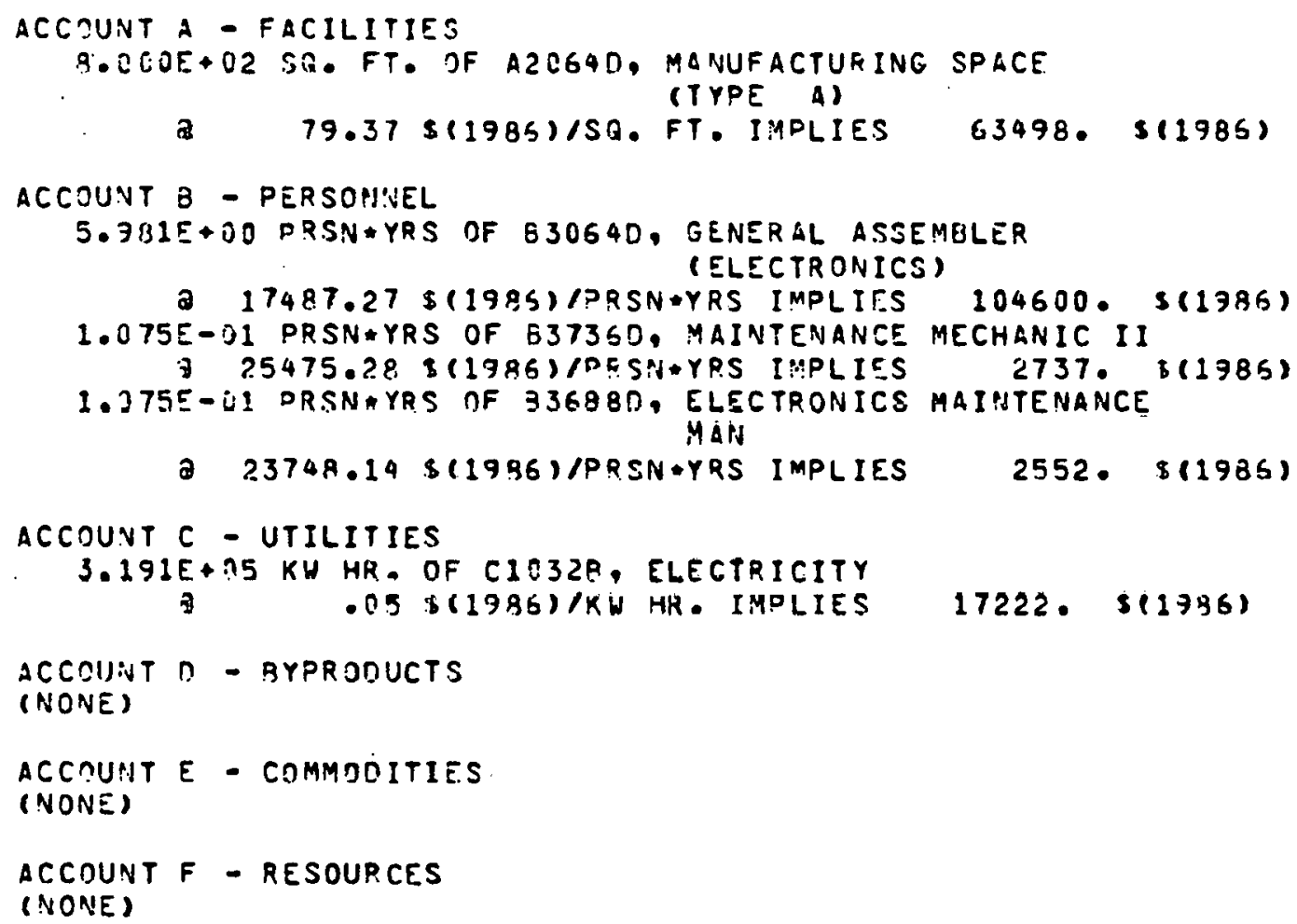




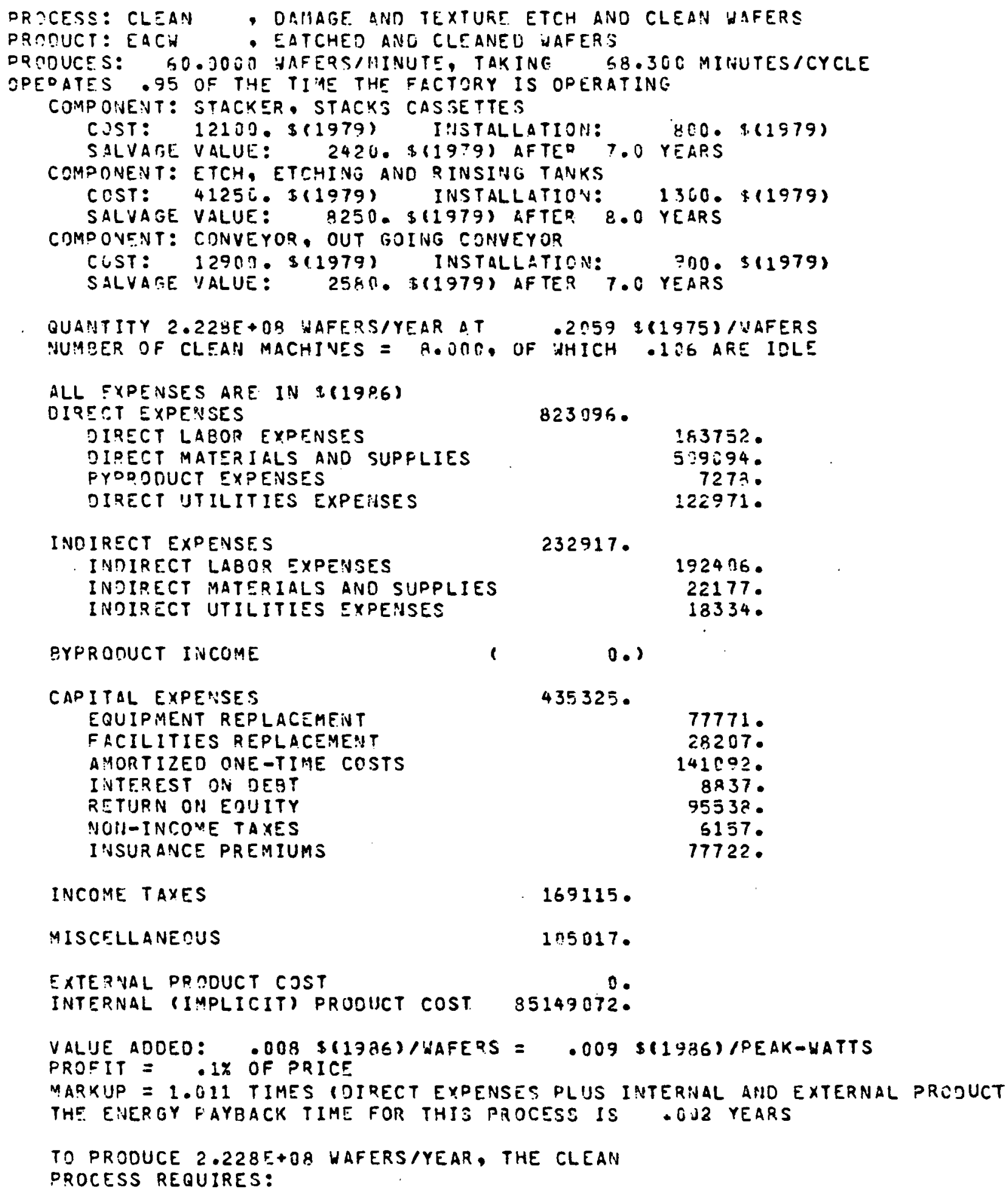

INCOME TAXES

169115

MISCELLANEOUS

105017

EXTERNAL PR DOUCT COST

INTERNAL (IMPLICIT) PRUDUCT COST 85149072 .

VALUE ADDED: .0DB \$(13a6)/WAFEQS = .009 S(1986)/PEAK-WATTS PROEIT $=$.I\% OF PRICE

MARKUP $=1.011$ TIMES IDIRECT EXPENSES PLUS INTERIVL AND EXTERNAL PRCDUCT THE ENERGY FAYBACK TIME FOR THIS PROCESS IS .OJ2 YEARS

TO PRODUCE $2.2285+0$ Q WAFERS/YEAR, THE CLEAN

PROCESS REQUIRES: 


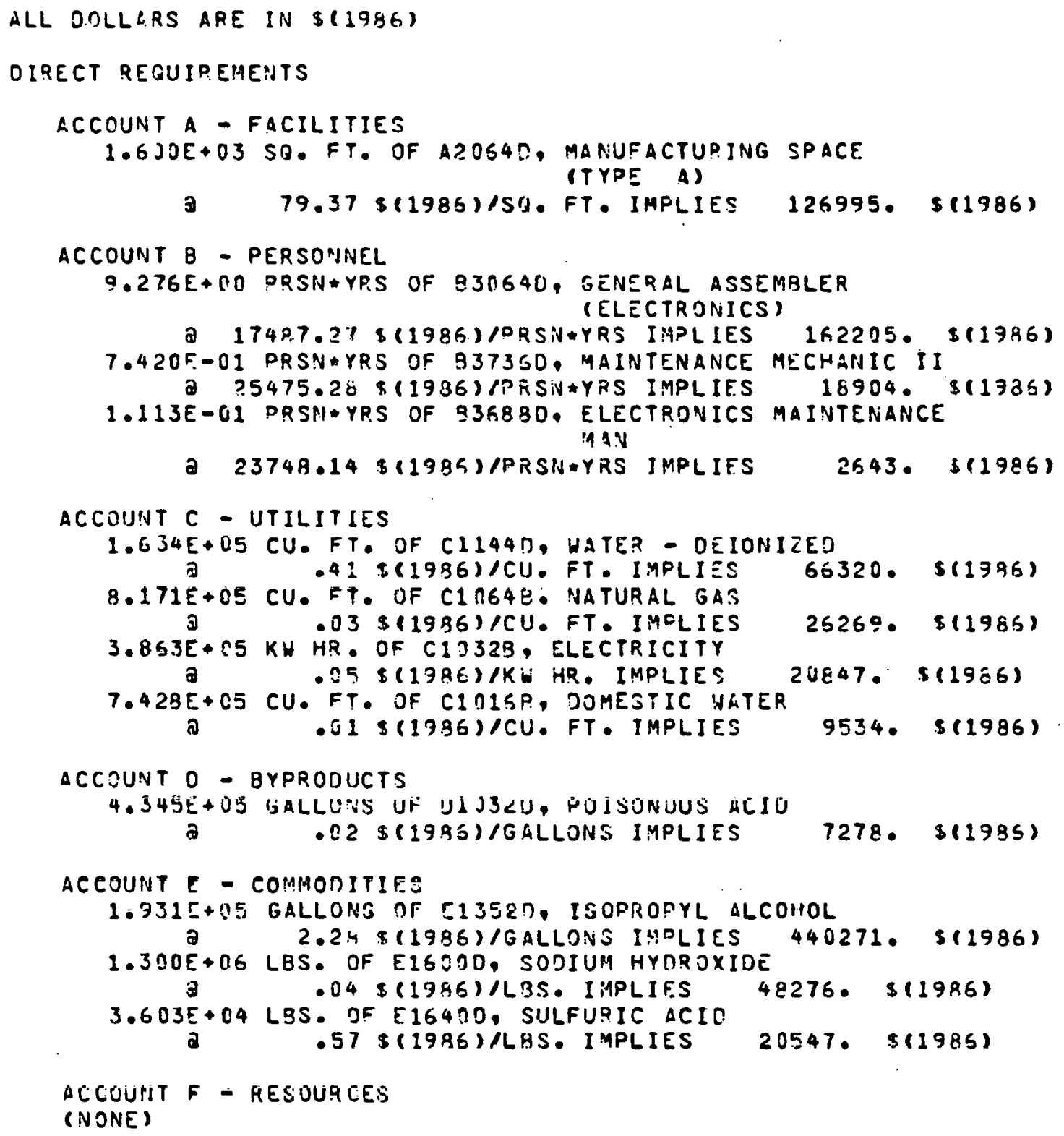




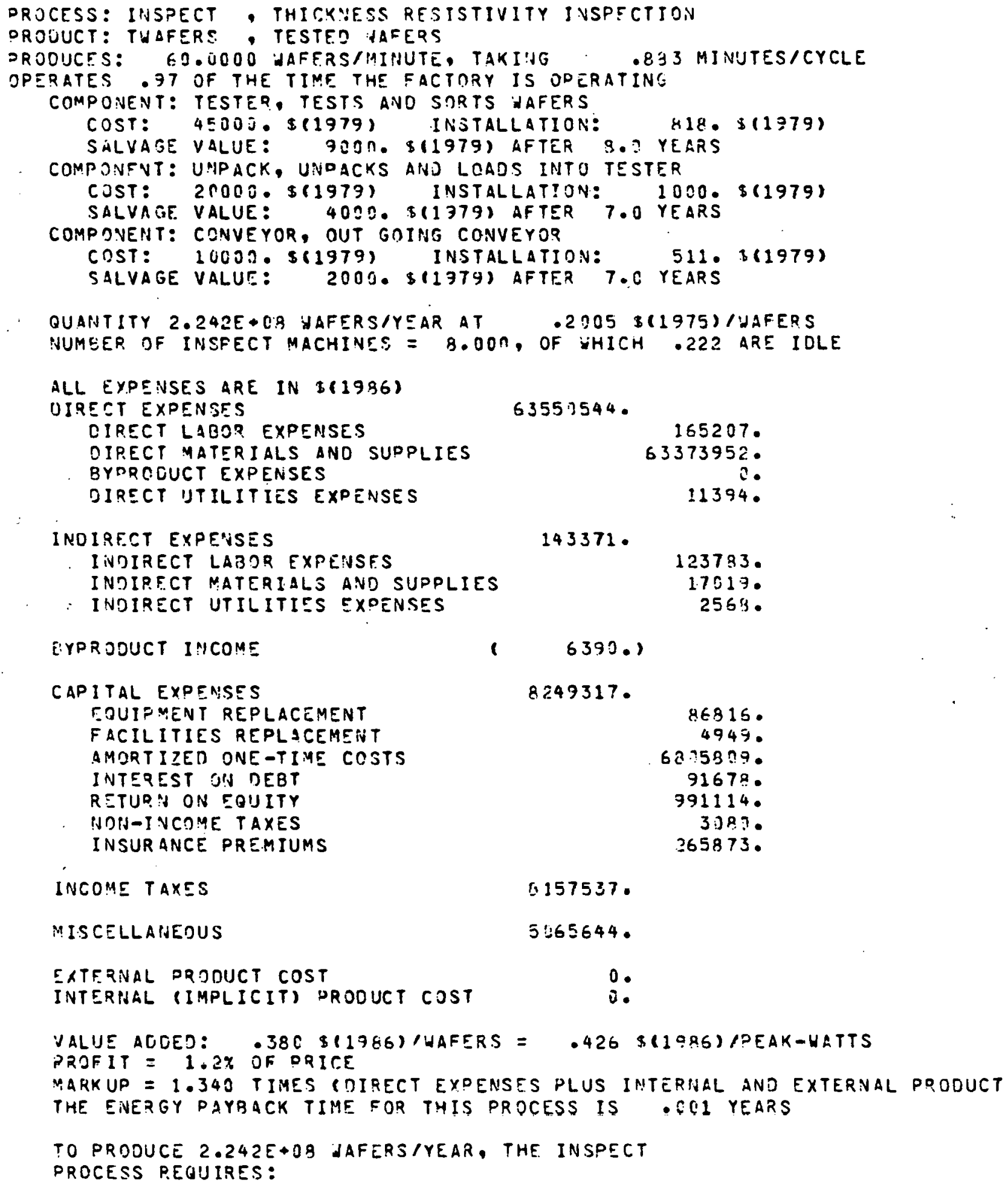

INCOHE TAXES

5357537

MISCELLAHEOUS

5,65644

EXTERNAL PRODUCT COST

INTERHAL (IMPLICIT) PRODUCT COST

0.

VALUE ACOED: .38C \$(1986)/HAFERS = .426\$(19.5) (PEAK-HATTS PRDFIT $=1.2 \%$ OF PRICE MARKUP $=1.340$ TIMES IDIRECT EXPENSES PLUS INTERHAL AND EXTERNAL PPODUCT THE ENERGY PAYAACK TIME FOR THIS PROCESS IS OCLI YEARS

TO PRODUCE 2.242E+09 JAFERS/YEAR, THE. INSPECT PROCESS PEOUIRES: 


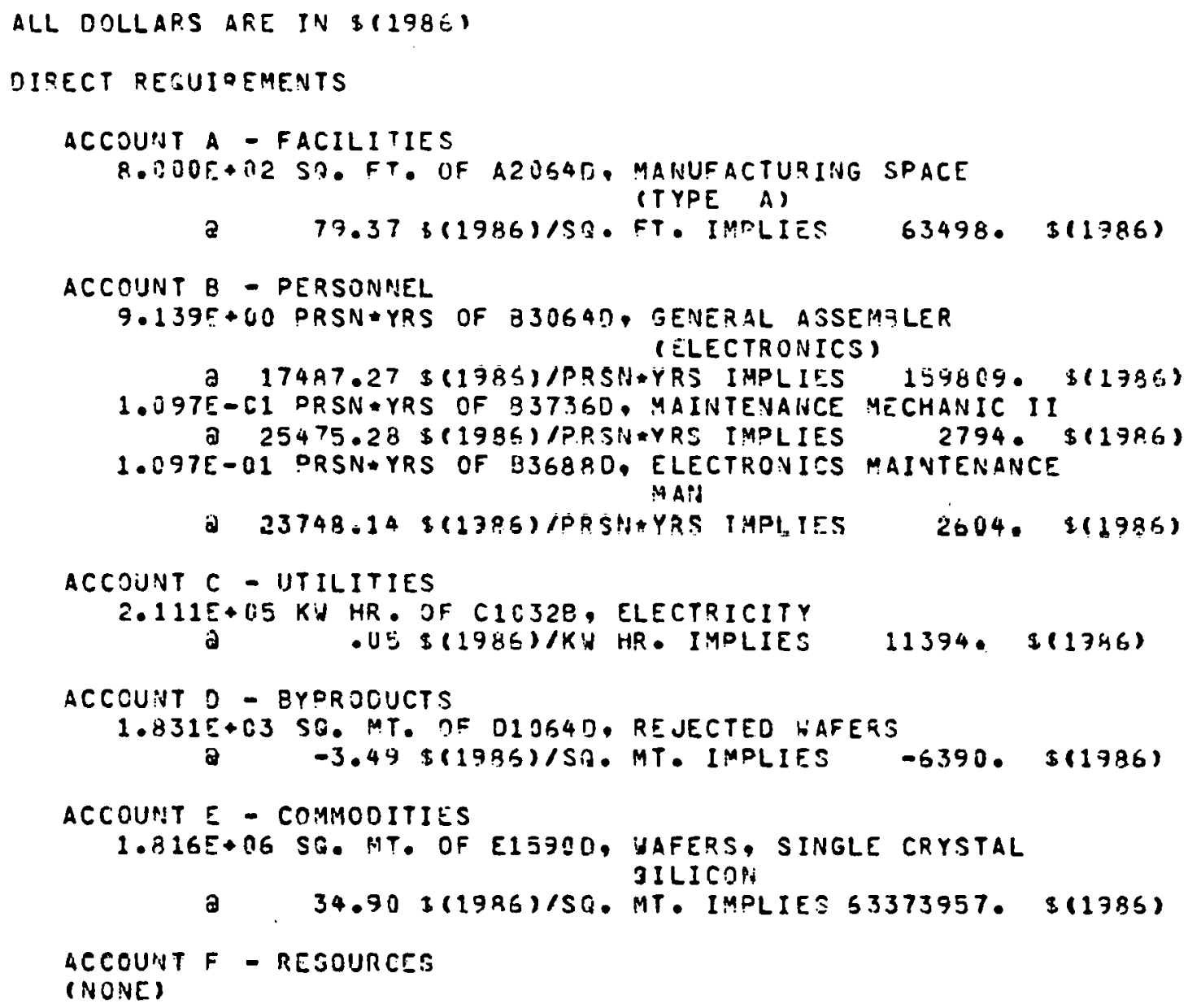


APPENDIX B

Butyl Based Sealant Characteristics 
REQUIFEMENT: Develop a new base sealant for sealed insulated glass with three primary benefits:

1. The seal shouid have outstanding MVT values and peel

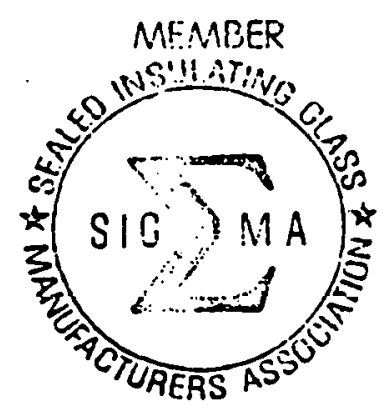
adhesion; resistance to weathering and elongation; and allow the manufacturer to extend his warranty.

2. Elapsed time between production and shipping should be significantly lower than with conventional sealants.

3. The sealant, and its method of application, should be cost-effective: that is, the sealant should be significantly lower in cost per gallon than existing sealants, and the way it is used should enable the sealed insulated glass manufacturer to produce units so efficiently that many of his manufacturing costs can be reduced. It is the third benefit, cost-effectiveness, that can determine how efficiently insulated glass is produced.

The sealant system thut combines rechnological advances with visible cost-eifectiveness will satisfy both manufacturing demands and customer demands. It will make its own case with manufacturers, based on its efficient sealing properties and its money-saving abilities.

ProDUCr: A secilarit with these three primary benefits is now avcilabie. It's H. B. Fuller Therma-Seal 1081, the new Butyl hot-melt sealant developed specifically for insulared glass. It includes a number of high-technology advances.

CHEMICAL BASE - BUtyl. COLOR - GrEY. TESTED UNDER SIGAiA SPFCIFICATION - 6.5-7.2. YFAR - 1974 STATIIS - PGSSOCd.

MOISTURE VAPOR TRANISMISSION: a) Lovver than the Butyl commonly used to mainufacture double-seal windows.

b) A single application shov's MVT values better than the combination Butyl/polysulfide construction.

DEAO LOAD SI.UMP TEST: Greuter resistance to Dead Load Slump than existing thermoplastic hot melts.

ELONGATION: Ovar $1000 \%$ elongation as meOsured on un Iristion lesting machine with corresponding ierislie strengit! sigrifiecintly better than polysuifides.

OVERLAP SHEAE TEST: Several limes higher in sheor strength when compered 10 existing thermopiastic hoi melts, and approasines the values obloinud with polyulfides.

PEEI ADHLSICN TEST: Considercibly ijofter adhesion to glass rand

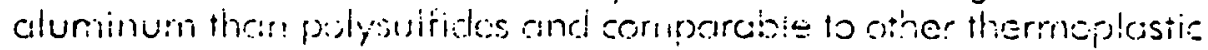
hoi melts. Ters metiod: TTS 00230-C.

TOXICITY: Fequires no loxic or hazarclous cetalyst is eifeci cure.

Thermo-Sea! 108! is a Butyl sealant. This sealant, lised in the sec'ind insulated glass industry, hos provided monufacturers with goco adhesion, good peei strength; a high resis:ance to weathering and to ultroviolet breakdown; high dead locd slump resistance; and

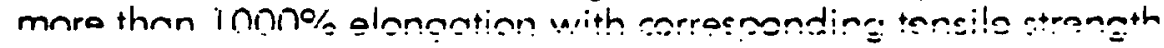


significantly higher than polysulfides. Overlap shear strength is aiso correspondingly high.

Thermo Sual 108 ! is a one conmmant Butyl sealant. Unitike other sealonts. Thermo.Seul 1081 has no solvent content. There is no evaporation of partici components, which eliminates toxicity. ThermoSeai 1081 is $100 \%$ solids, which restricts sealant breakdown over long periocis of tinie. Therno-Seal 1081 maintains its stability, and its adhesive qualities, throughout the estimated life of the window unit.

Thermo-Seal 1081 is a hot-nelt Bury' sealant. The application of the sealant in this way offers an exceptionally flexible seal that sets very quickly. The hot Butyl exhibits excellent flow characteristics, and its quick set eliminates sealant crystallization. In addition, hot-melt Butyl gives the sealed insulated glass manufacturer a seal with a considercibly lower Moisture Vapor Transmission characteristic. Thermo-Secl 1081, then, is a one-component. Butyl hot-meit seclant that offers the manuficturer the following product benefits:

- Excellent sealing qualities - Extreme stability - Low MVT value

- No toxicity - Long life

SYSTEM: When Therma-Seal 1081 is considered as part of a system, it offers the sealed insulated glass manufacturer a good opportunity to copitalize on cost-effective unit fabrication.

Because of Thermo-Seal 1081's superb qualities, double-sealing can be elimincited. This allows the manufacturer to simplify his production line. And one-component Thermo-Seal 1081 eliminates the need for complicaied two-pump application systems, as well as the problems inherent in twa-component sealant balancing, handling, and quality control.

Because Thermo-Seal 1081 is used ir a hot-melt form, application is fast. However, the recl test of effectiveness comes from the window unit's "ready time" - polysulfide sealanis must be allowed to cure for several hours, perinaps longer. Thermo-Seal 1081 Butyl șeis in minuies; clean-up cari be accomplished at the work-station; and the window unit is ready for shipmen as scon as it comes off the line. H. B. Fuller is able to ofeer the equipment necessary to ensure proper and profitable application of Thermo-Sea! 1081 to the sec!ed insulated gloss industry.

Thermo-Seal 1081 allows the sealed insulated glass manufacturer to take advantace of several cost-efístive sy'siem cenefits.

- The ability to produce secled window units in less ioral elapsed time

- The abiiity to contro! product quality un-station

- The cuility to lower preduction cosis due to equipment simplification

- The ability io lower tctal unit cosis jue io increcised productionline efficiency 
THIS PAGE

WAS INTENTIONALLY

LEFT BLANK 


\section{APPENDIX C \\ Accelerated Weathering Test Specifications \\ for Sigma and CE Glass}


,

THIS PAGE

WAS INTENTIONALLY

LEFT BLANK 
COMPARISON OF CE GLASS REQUIREMENTS VERSUS SIGMA REQUIREMENTS

\section{SIGMA Requirements}

A. The new SIGMA requirements are summarized as follows:

1. No fallure of 9 out of 10 units at partial vacuum of 3.0 inches of mercury for $21 / 2$ hours at $75^{\circ} \mathrm{F}$.

2. Initial Dew Point $-60^{\circ} \mathrm{F}$

3. Accelerated Weathering

a. 2 weeks C $140^{\circ} \mathrm{F}$ and $100 \%$ R.H.

b. 240 cycles which include

1. 2 hrs. $-20^{\circ} \mathrm{F}$

11. 1 hour spray C $140^{\circ} \mathrm{F}$

iif. I hour dry U.V. @ $120^{\circ} \mathrm{F}$

4. Summary

The accelerated weathering summary is as follows:
a. 2 weeks $140^{\circ} \mathrm{F}$ and $100 \%$ R.H.
b. 240 cycles from -20 to $120^{\circ} \mathrm{F}$
c. 240 hours dry U.V. at $120^{\circ} \mathrm{F}$
d. 10 days spray e $140^{\circ} \mathrm{F}$

B. CE GLASS Requirements - 8 weeks of testing - 2 weeks in each apparatus

1. Intial Dew Point $-60^{\circ} \mathrm{F}$

2. 50,000 cycles at $150^{\circ} \mathrm{F}$ and $100 \%$ R.H. and \pm 8 inches of water pressure/vacuum cycling

3. 2 weeks at $150^{\circ} \mathrm{F}$ and $100 \%$ saturation plus continuous U.V. exposure

4. 2 weeks at Dry U.V. at $150^{\circ} \mathrm{F}$ continuous

5. 70 cycles from $0^{\circ} \mathrm{F}$ to $105^{\circ} \mathrm{F}$

c. Summary

1. Both SIGMA and CE GLASS have identical requirements for Initial Dew Point. 
2. SIGMA tests each unit once for partial vacuum, CE GLASS subjects each unit to 50,000 cycles of partial vacuum and pressure at $150^{\circ} \mathrm{F}$ and $100 \% \mathrm{R} . \mathrm{H}$. which greatly exceeds the SIGMA requirement.

3. SIGMA gives each unit 240 cycles of $-20^{\circ} \mathrm{F}$ to $140^{\circ} \mathrm{F}$ while CE GLASS subjects each unit to 70 cycles from $0^{\circ} \mathrm{F}$ to $150^{\circ} \mathrm{F}$. The increase in temperature of $10^{\circ} \mathrm{F}$ is equivalent to a $.7 \mathrm{X}$ factor (each $15^{\circ} \mathrm{F}$ rise doubles the rate of chemical activity) so that 70 cycles at $150^{\circ} \mathrm{F}$ is equivalent to 120 cycles a $140^{\circ} \mathrm{F}$. It is felt that the CE GLASS test is more rigorous because of the higher temperature.

4. SIGMA subjects units to a total of 240 hours at dry U.V. at $120^{\circ} \mathrm{F}$ - while CE GLASS subjects units to 336 hours of dry U.V. at $150^{\circ} \mathrm{F}$.

5. SIGMA subjects units for 24 days at $140^{\circ} \mathrm{F}$ and $100 \%$ R.H. while CE GLASS subjects units for 2 weeks at $150^{\circ} \mathrm{F}$ and $100 \%$ R.H. while the units are continually exposed to U.V. light.

D. Conclusion

In all aspects of testing CE GLASS subjects the units to a more rigorous test cycle than the SIGMA spec. tests. It is felt that 8 weeks of testing in the CE GLASS test cycles is considerably more rigorous than the SIGMA specification requirements. 


\section{APPENDIX D}

Hot Melt Application Equipment Manufacturers Data 

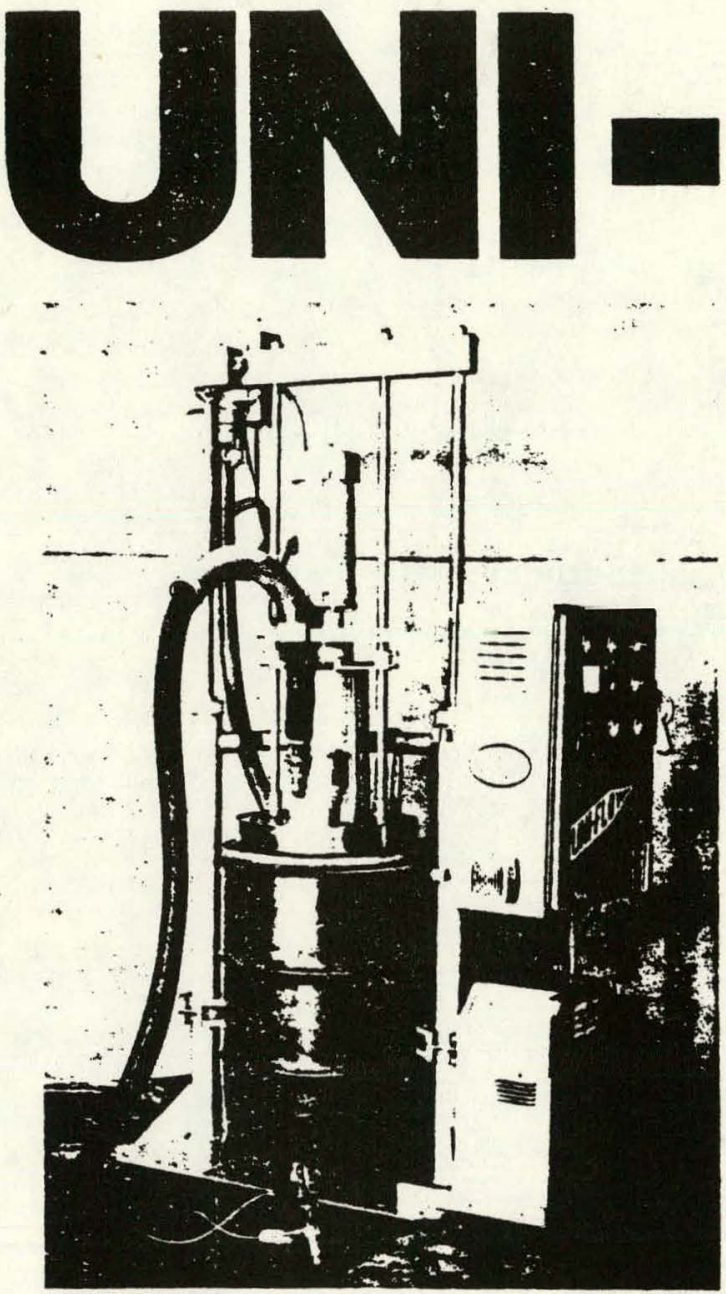

MODELS.P.
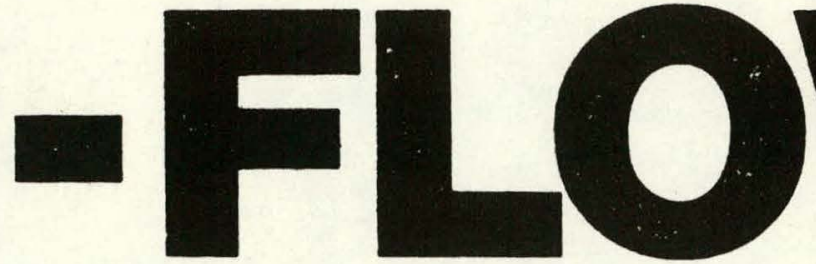

Break technology for high volume high viscosities.

The Uni-Flow system was designed to handle high viscosity thermoplastic sealants and adhesives while solving the problems associated with previously available systems. The technological advances incorporated in the Uni-Flow system allow it to melt down and deliver hot melts under nearly ideal conditions for top performance.

\section{If You Couldn't Pump Before, You Can Pump Now!}

Pumping - Metering - Dispensing from 55 gallon drum. Molten viscosities from 1,000 cps to $9,000,000$ cps.

\section{Advantages of the UNI-FLOW System ...}

- positive displacement-nn skips or gaps in the bead

- faster throughput than other systems -up to $20 \mathrm{lbs}$./min.

- takes standard 55 gallon drums-save expense by allowing the user to buy in léss expensive bulk form

- positive heat control at all zones-virtually eliminates bufn-up of material and bum-out of the equipment in hot spots and applies the hot melt at optimum temperature $-100^{\circ} \mathrm{F}$ to $500^{\circ} \mathrm{F}$ continuous

- can be adapted to automatic extrusion systems

Developed \& Manufactured By:

INDUSTRIAL MACHINE MANUFACTURING, $\mathrm{CO}$. 


\section{Features:}
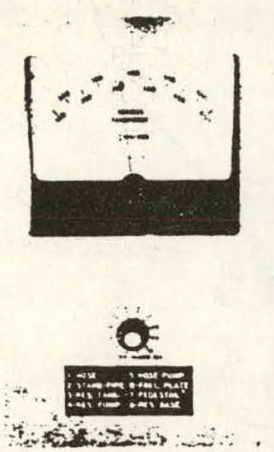

METER

READOUT

Provides a continuous readout of each of the eight temperature zones by use of a platinum resistance sensor common to the cintroller circuit (i.e. meter reads the exact temperature sensed by trit controller)

FOLLOWER PLATE

Newly designed follower plate contains 21 replaceable cartridge heaters producing a total heating capacity of $21.3 \mathrm{KW}$ over 5400 square inches of finned surface area. A low watt density of six watts per square inch prevents localized material overheating, charring, cross-linking. etc.
RUN/STAIVL

BY SWITCH

This switch turns the unit back to a lower pre-set "stand-by" temperature during non-use periods. making it possible to bring the unit up to operating temperature within five minutes after returning switch to the "run" position.

\section{HAND GUN}

Capable of producing variable bead diame ters with low force, finger tip control. The trigger has a special 12 to 1 force multiplier linkage permitting minute valve openings for the first half inch of trigger travel. This enables the operator to fill corners or start a bead without a large, surging glob. The hand gun also has an adjustable stop for producing a fixed bead diameter at full trigger travel, alleviating operator finger fatigue.

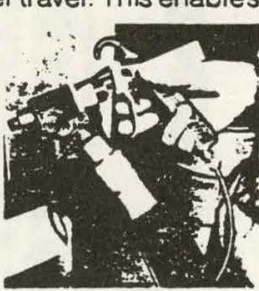

HEATED FLEXIBI.E.HOSE

The hose incorporates an internal electric resistance heater which is in direct contact with the material (not a wrap around type heater as in conventional hoses). The heater is actually inside the teflon liner of the metal braided hose. This produces much more efficient heat transfer than in conventional hoses, thus permitting hıgher material temperatures without overheating or degrading the teflon liner. The material temperature is precisely controlled by a platinum temperature sensing probe also located inside the hose and in direct contact with both the sealant and the heating element. The meter reading of the hose temperature is actuaily a direct readout of the material temperature at the nozzle.

\section{DISPENSING PUMP}

The positive displacement gear pump dispenses up to 15 lbs. per minute with non-surging flow at rated pressure for a smooth gap-free bead.

\section{TEMPERATURE CONTROLLERS}

These specially designed plug-in, $2^{\prime \prime} \times 2$ " solid state temperature controllers are capable of holding each of the eight heat zones to within $3^{\circ}$ to $4^{\circ} \mathrm{F}$. of set-point. A red "i- ' on the card provides easy visual inspection for proper functioning.

\section{Specifications:}

OVERALL SIZE: width 32 inches; length (panel face to back post) 55 inches; herght (beam fully raised) 116 inches.

\begin{tabular}{ll}
\hline WEIGHT: & $900 \mathrm{lbs}$ (empty) \\
\hline AIR & 80 psi minimum, 100 psi \\
REQUIREMENTS: & recommended, 150 psi maximum.
\end{tabular}

AIR CONSUMPTION: less than 1 scfm continuous.

\begin{tabular}{|c|c|}
\hline $\begin{array}{l}\text { ELECTRIC SERVICE } \\
\text { REQUIREMENTS: }\end{array}$ & $\begin{array}{l}208 / 240 / 480 \text { vac, } 3 \text { phase, } \cdot 100 \\
\text { amp entrance. }\end{array}$ \\
\hline $\begin{array}{l}\text { POWER } \\
\text { CONSUMPTION: }\end{array}$ & $\begin{array}{l}63 \text { amps/at } 240 \text { vac (start-up only, } \\
20 \text { min. average start-up time); } 31 \\
\text { amps (continuous dispensing) }\end{array}$ \\
\hline $\begin{array}{l}\text { TEMPERATURE } \\
\text { RANGE: }\end{array}$ & $100^{\circ}$ to $500^{\circ} \mathrm{F}$ (continuous). \\
\hline $\begin{array}{l}\text { MATERIAL FLOW } \\
\text { RATE: }\end{array}$ & $\begin{array}{l}\text { approximately } 15 \mathrm{lbs} / \text { minute at } \\
50,000 \mathrm{cps} ; 1.2 \mathrm{lbs} / \text { minute at } 9 \\
\text { million cps. }\end{array}$ \\
\hline START-UP TIME: & 20 minutes average (from $65^{\circ} \mathrm{F}$ ). \\
\hline
\end{tabular}

Developed \& Manufactured By:

INDUSTRIAL MACHINE MANUFACTURING, $\mathrm{CO}$.

1005 Holly Spring Road

Richmond, Virginia 23224 


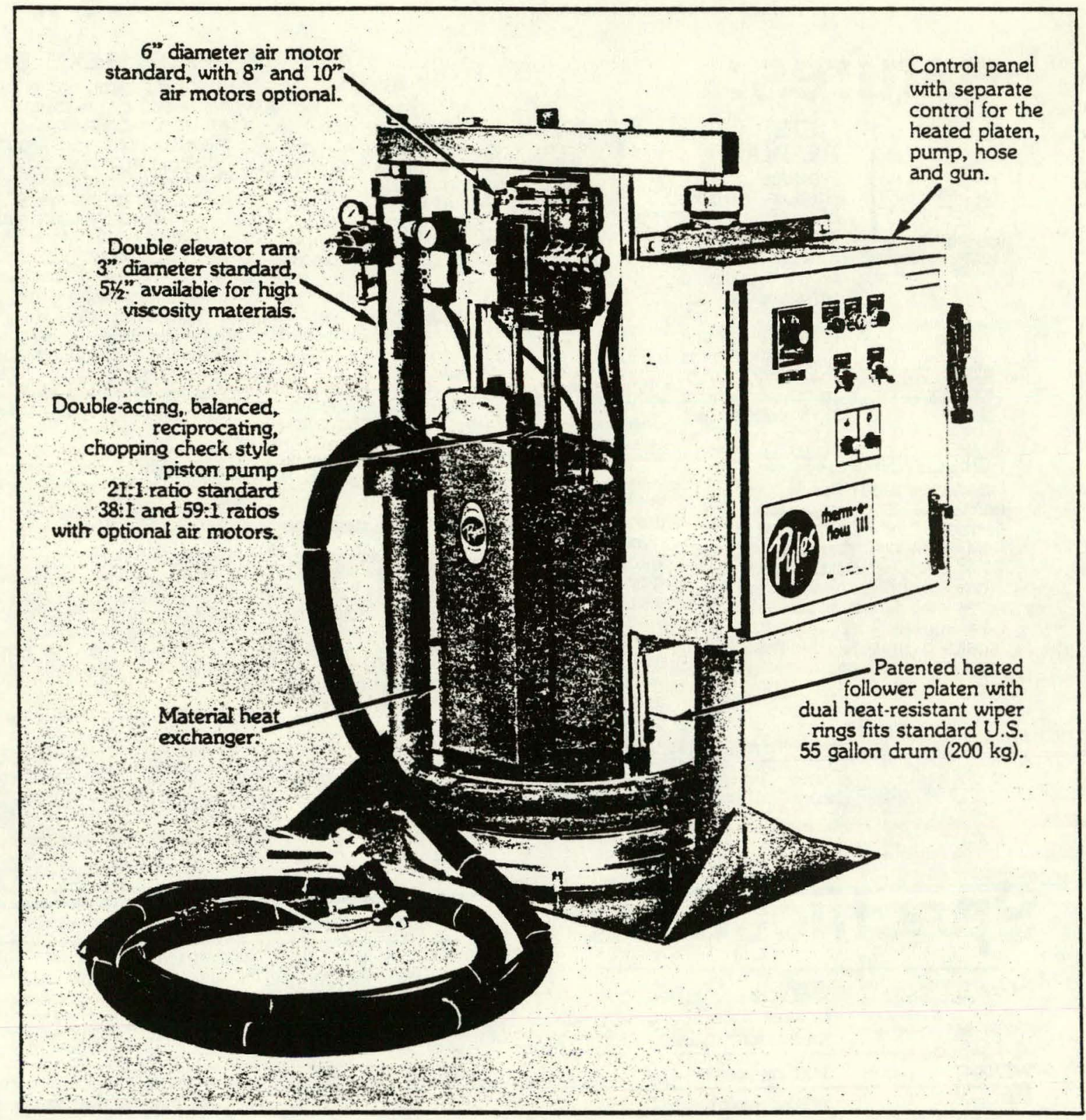

Pumping

Metering

Mixing

Measuring

Dispensing
Pyles Industries, Inc. through an extensive research and development program, has perfected a system for handling materials with a wide viscosity range at elevated temperatures. Materials with molten viscosities from $500 \mathrm{cps}$ to $4,000,000 \mathrm{cps}$ may be applied directly to the part from the original bulk shipping containers. No longer is there a need to handle reprocessed materials in block, chip, granular or pillow form in hopper type dispensers. Pyles Industries thermo-D-flous III will allow you to develop tomorrow's production methods and materials today. 


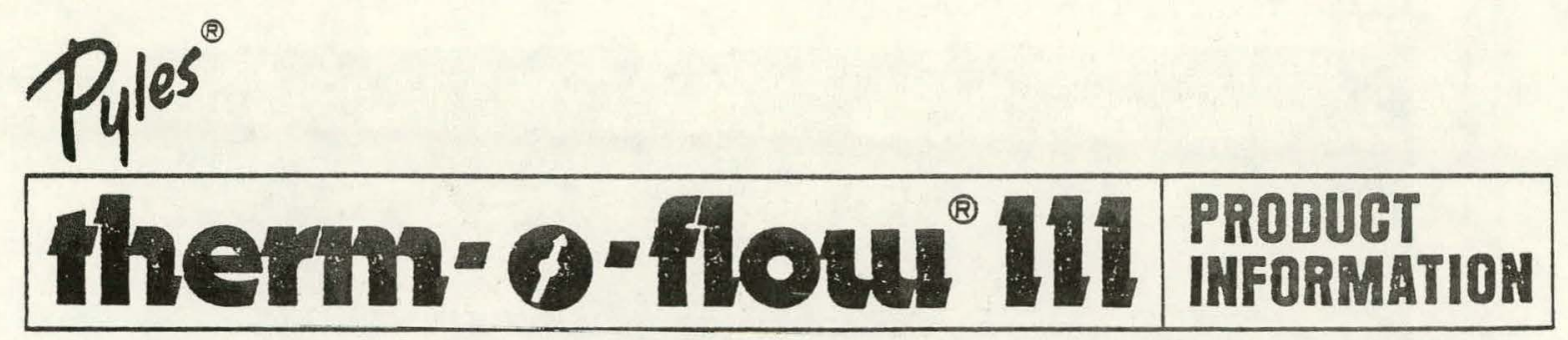

\section{OPERATING PRINCIPLES}

Material in its bulk 55 gallon shipping container is placed on the base plate of the unit. The elevator is lowered to bring the heated follower platen into contact with the surface of the material. The upper layer of the material is melted and with the assistance of the follower ram pressure, is forced into the pump. The heated pump then pressure feeds the material through a heat exchanger, heated hose and gun to the substrate. As material is pumped from the container, the elevator lowers automatically to keep continuous contact between the material and the heated follower platen.

\section{SYSTEM FEATURES}

- Handles any meltable material direct from the original 55 gallon shipping container.

- Heats only the material about to be used to application temperature in a completely closed environment. This demand heating principle elim. inates induced polymerization, thermal degradation, and oxidation caused by uneven heat, bulk heating for extended periods, and heating in open atmosphere.

- Temperature control ranges from 0 to $450^{\circ} \mathrm{F}\left(235^{\circ} \mathrm{C}\right)$. Accuracy is $\pm 1 \%$ of the scale reading.

- The follower platen covers the material and protects it from the contamination and wipes the container clean of material.

- The system may be used to bulk feed existing hopper type units.

\section{TECHNICAL DATA}

- Heat is transferred by a cast-in element secured to the follower platen. The platen temperature can be maintained at $\pm 2 \%$ of the scale reading. Ad. justable in $10^{\circ}$ increments from ambient to $400^{\circ} \mathrm{F}$ $\left(205^{\circ} \mathrm{C}\right)$.

- Heating capabilities depend on the specific heat of the materials selected. The heat available at the follower is rated at 39,000 BTU. There are 630 square inches of effective heating surface below the follower platen.

- Basic pumping unit is a Pyles' standard 716-11-200 double elevator, double-acting $21: 1$ ratio chopping check pump. Ratios of $38: 1$ and $59: 1$ are available.

- Start up time for an enterely cold system is 30 to 45 minutes. Start up time when changing to a new drum is 7 to 15 minutes.

- For materials with application temperatures between $400^{\circ}$ and $450^{\circ} \mathrm{F}\left(205^{\circ} \cdot 235^{\circ} \mathrm{C}\right)$, the standard five zone heating system may be used to increase the material temperature from the melting point to the final application temperature.

- Output rates must be determined for each individual material and application. Completing and returning the "Request for Quotation" form sheet will enable us to do this for you.

- Special units are available on request for applica. tions requiring output temperatures in excess of $400^{\circ} \mathrm{F}\left(205^{\circ} \mathrm{C}\right)$

\section{SYSTEM COMPONENTS}

23208 Basic memo-nonum complete with 3" double ele23240 vator ram, heated follower platen and pump, air and 23380 electrical heating controls. Model number indicates 23480 voltage required.

A $5 \frac{1}{2}$ " elevator ram is available for high viscosity materials. To specify, add -50 to the base model number (e.g 23240-50).

\section{ACCESSORIES}

23000-45

$23000-60$

23000.61

$23000-65$

$23000-75$
Heat Exchanger

Low Material Level Indicator Kit

Automatic Dual Pump Crossover Control

7 Day Pre-Production Start Up Timer

Tamper Proof Control Cover Kit

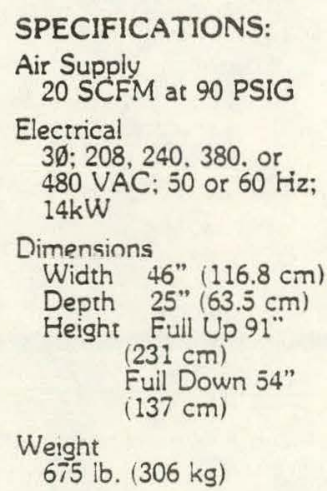




\section{GUNS AND HOSES}

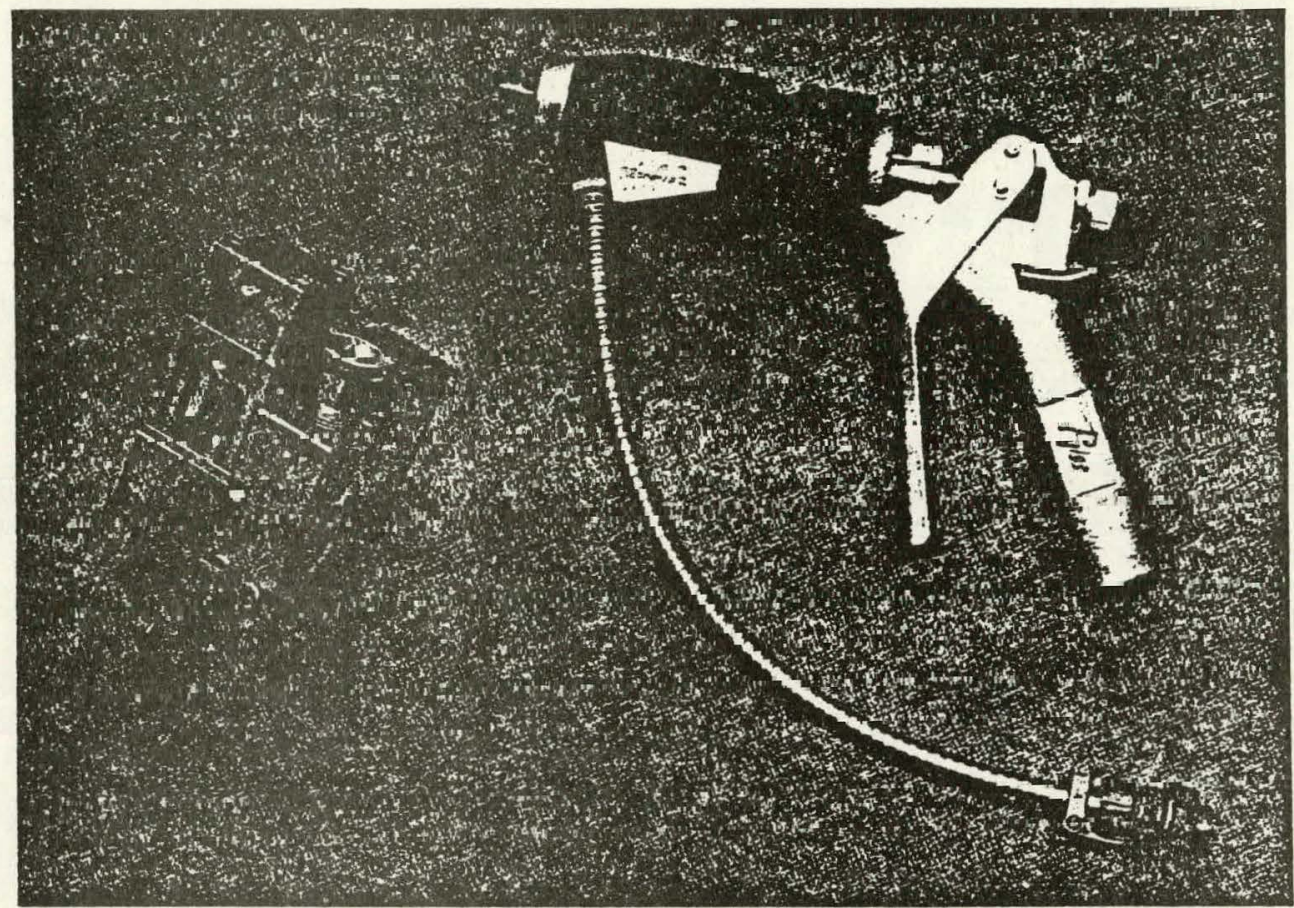

22000-200-R Automatic Gun

22000-100 Manual Gun

$220 ก \cap-100$

Manual dispensing gun with cartridge heater. Nozzle orifice .031" standard. Other orifices and configurations available upon request.

$22000-200-R$

Automatic dispensing gun with heater. conntrnller, and thermomoter. Double air operated, requires a 4-way valve to actuate. Nozzle orifice $016^{\prime \prime}$ standard, other orifices available.

22000-85

Temperature controller. One required for each hose and manual gun.

Standard Heated Hose Assemblies (2,000 PSI W.P. - 6,000 PSI B.P.)

22008-B

22015-B

$22020-B$

23010-B

23015-B

23020-B

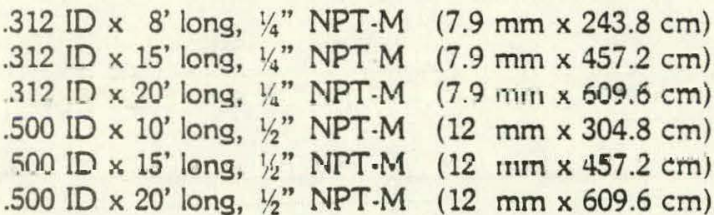

High Pressure Heated Hose Assemblies (4,000 PSI W.P. - 12,000 PSI B.P.). NOTE: THESF IIOSES ARE REQUIRED WITH IIIE OPTIONAL 38:1 AND 59:1 PRESSURE RATIOS.

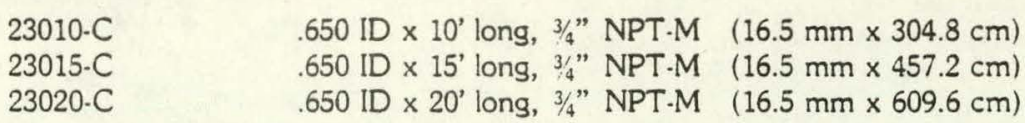

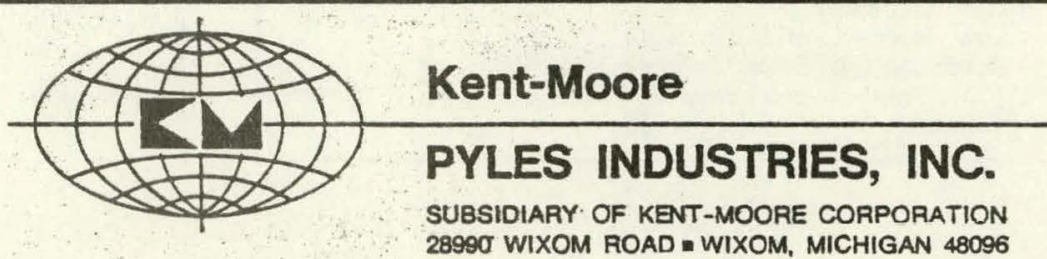




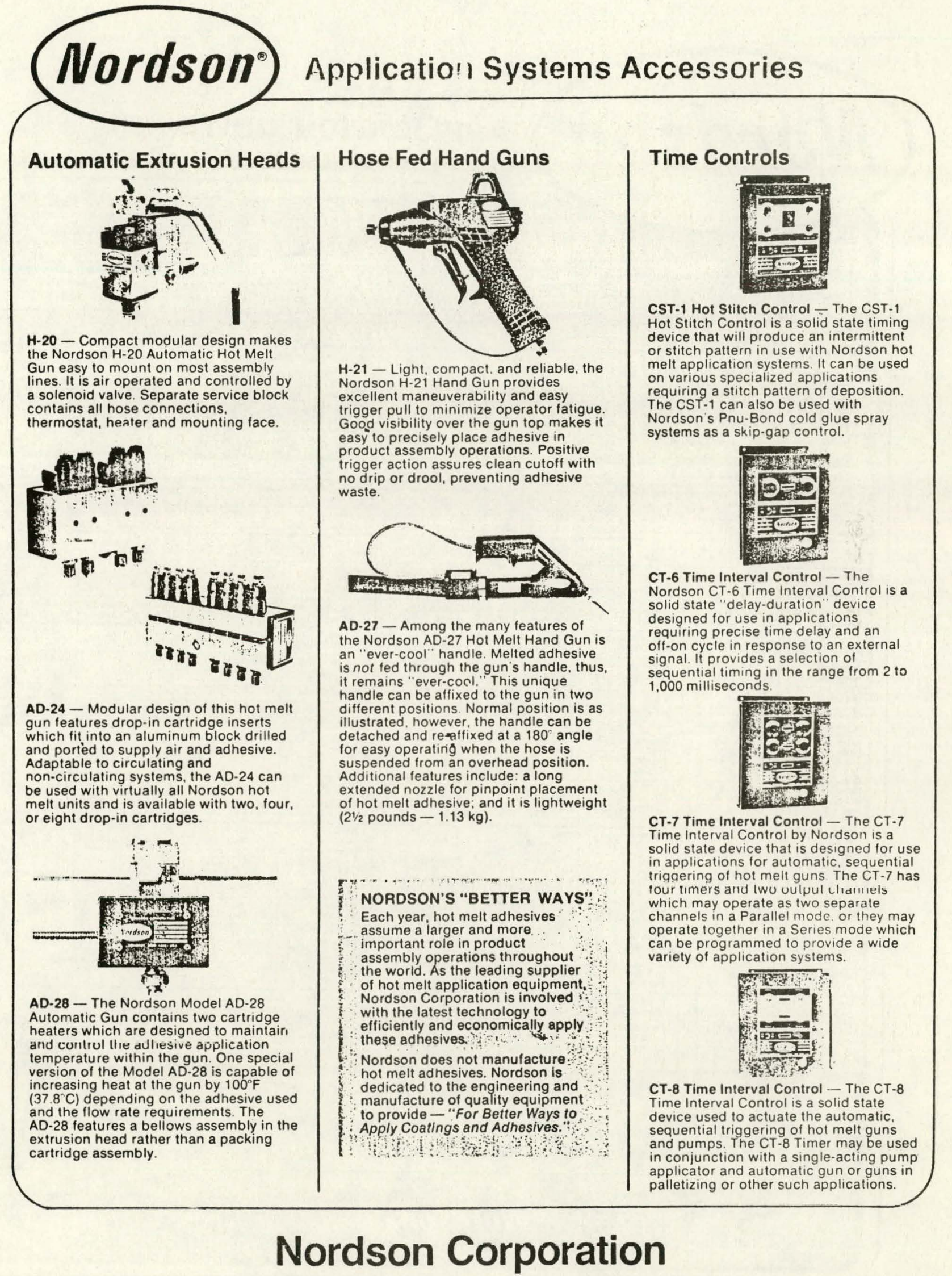

555 Jackson Street, P.O. Box 151 - Amherst, Ohio 44001 


\section{Nordsom for Product Assembly}

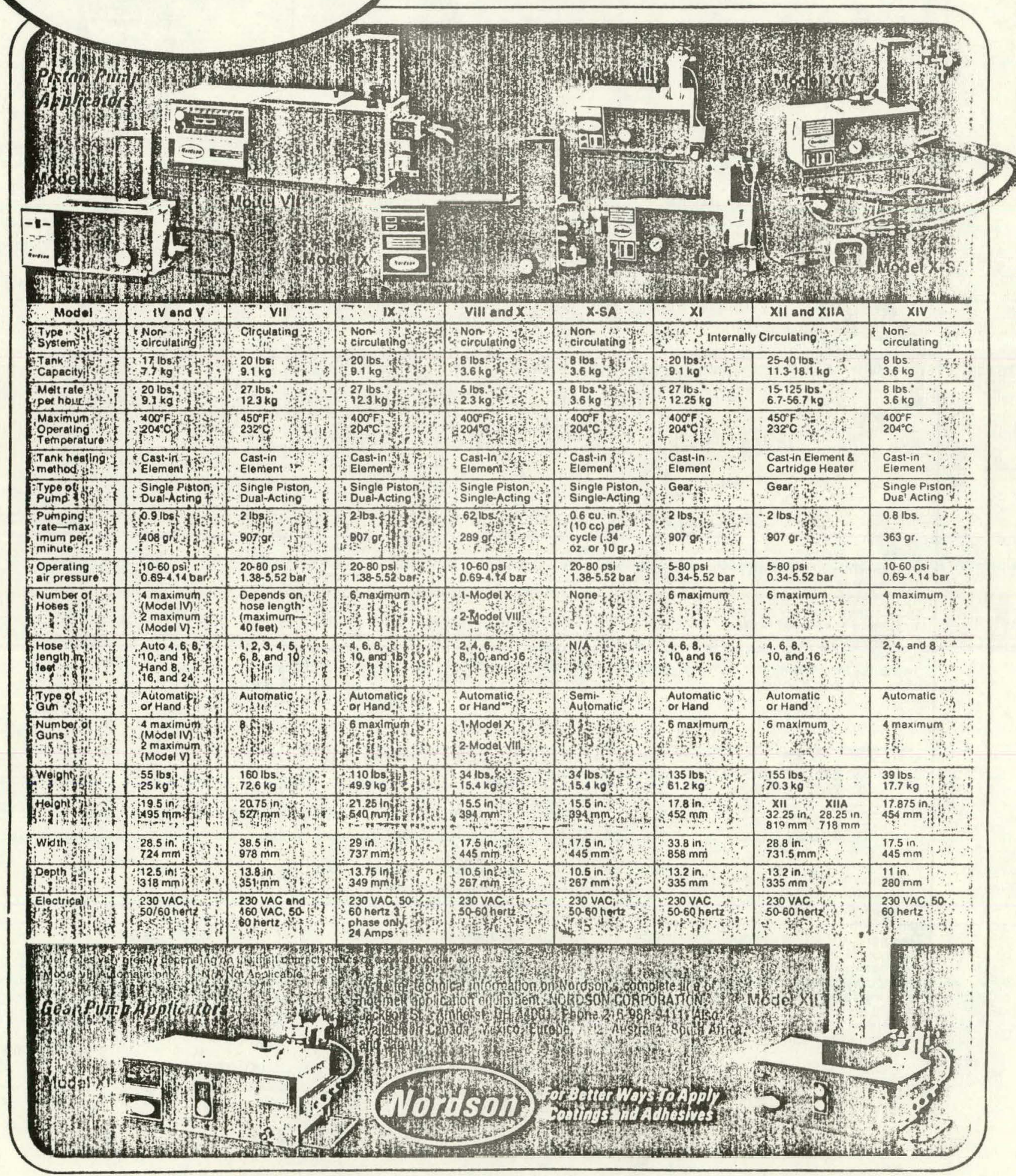


APPENDIX E

Unimate 2000 Industrial Robot Characteristics 


\section{Leadership through product superiority}

Unimation Inc. pioneered the development of the industrial robot and has maintained its leadership role through product superiority and technological ingenuity.

Today, the industrial robot is used in manufacturing operations throughout the world to perform tasks that are too hazardous, too onerous, too boring, or simply too uneconomical for humans.

In most applications, the robot can handle heavier loads more accurately and at higher speeds for longer periods of time than its human counterpart. This results in increased productivity, lower operating costs and products with greater uniformity and precision.

The proven performance of UNIMATE industrial robots is derived from millions of hours of productive work in many different industries. Their durability is attested to by the many machines that are hale and hearty and still earning their keep after 65,000 hours of operationthat's over 32 man years of work.

The diversity of applications and proven endurance of the UNIMATE illustrate its versatility and are your assurance of a sound investment.

\section{A matter of flexibility}

Fexibility is the key to what the Unimate offers. This industrial robot not only adapts to new applications but it adapts to new requirements within an existing process.

The most efficient hard or specialpurpose automation can become instantly obsolete if the product or process changes. In contrast, the sophistication of the Unimate invests it with the flexibility to adapt to changes... and in no more time than it would take a human worker.

The Unimate includes up to 6 fully programmable degrees of freedom. Its motions are hydraulically actuated for heavy payioads, smoothness of operation and durability. Its solid state, nonvolatile memur y has a capacity for as many as 1024 program steps point-topoint (PTP) and is easily adapted to specific job requirements.

This flexibility provides built in nonobsolescence and long term cost effectiveness. It makes the Unimate robot your best automation investment.

\section{Features that count}

There are several models of the Unimate robot and many available options designed to meet your needs at the lowest possible cost. The 2000 series Unimates can handle payloads up to approximately 125 lbs., while the 4000 series can handle up to $500 \mathrm{lb}$. loads. All models include the following proven design features that assure exreptional performance and reliability.

Muscle power: Hydraulic servoing of all degrees of freedom provides the power for high speed operation with smooth acceleration and deceleration. Servo control: The control system is $100 \%$ digital. This assures positive positional accuracy with neither short nor long term drift nor the need for zeroing. Solid state electronic components are used throughout for high reliability. Non-volatile memory: The solid state programmable memory (PROM) is the ultimate in reliability because there are no moving parts nor tapes to wear or

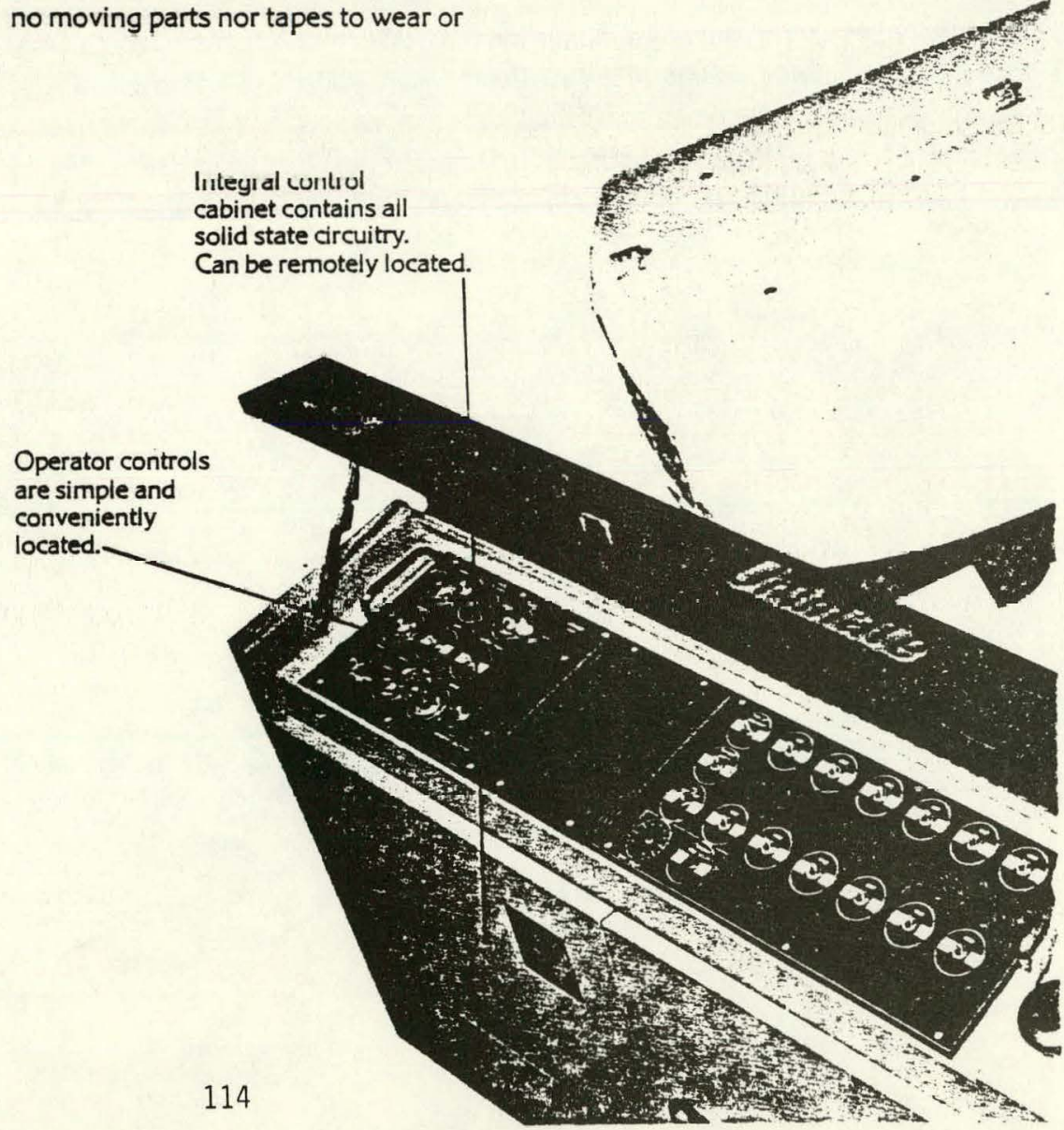

stretch. Retention of memory, regardless of electrical power loss or transients, is indefinite. Many memory sizes and functional arrangements are available.

Controls and interlocks: Operator controls are conveniently arranged in the control cabinet. Electrical connections are easily accessible to interlock the Unimate with the equipment it serves, including programmable functions to insure safe and efficient operation. In addition, interfacing within a computer controlled hierarchy is readily accomplished.

Millions of hours of field performance assure unsurpassed reliability. -

Sturdy covers protect equipment and enclose all pinch points. 
No. of degrees of freedom: All models are available with from 2 to 6 fully programmable degrees of freedom.

Easy to teach: The Unimate is designed for "on-the-job" training. No computer type programming preparation or cumbersome hard wire sequencing is required. Within one hour, anyone can learn to teach Unimate the job because the robot is literally led by the hand through the operations to be performed, point-to-point. Playback speeds are independent of the teaching speed. The teach control is a compact, hand held, plug-in unit.
Easy to maintain: Simple procedures help to assure proper maintenance of the Unimate. You get proper maintenance schedules and instructions for sustained, trouble free operation. Modular construction, combined with definitive trouble shooting guides also helps you to maintain the robot.

Options and accessories: In addition to the essential features already described, many options and accessories can be selected to extend the robot's flexibility.
For example, multiple programs can be stored in the memory and called upon at random; base and sub routines can be taught to facilitate complex material handling and palletizing operations; portions of programs can be altered to accommodate external variables without interrupting the operation; motions can by synchronized with continuously moving conveyors; and programs can be

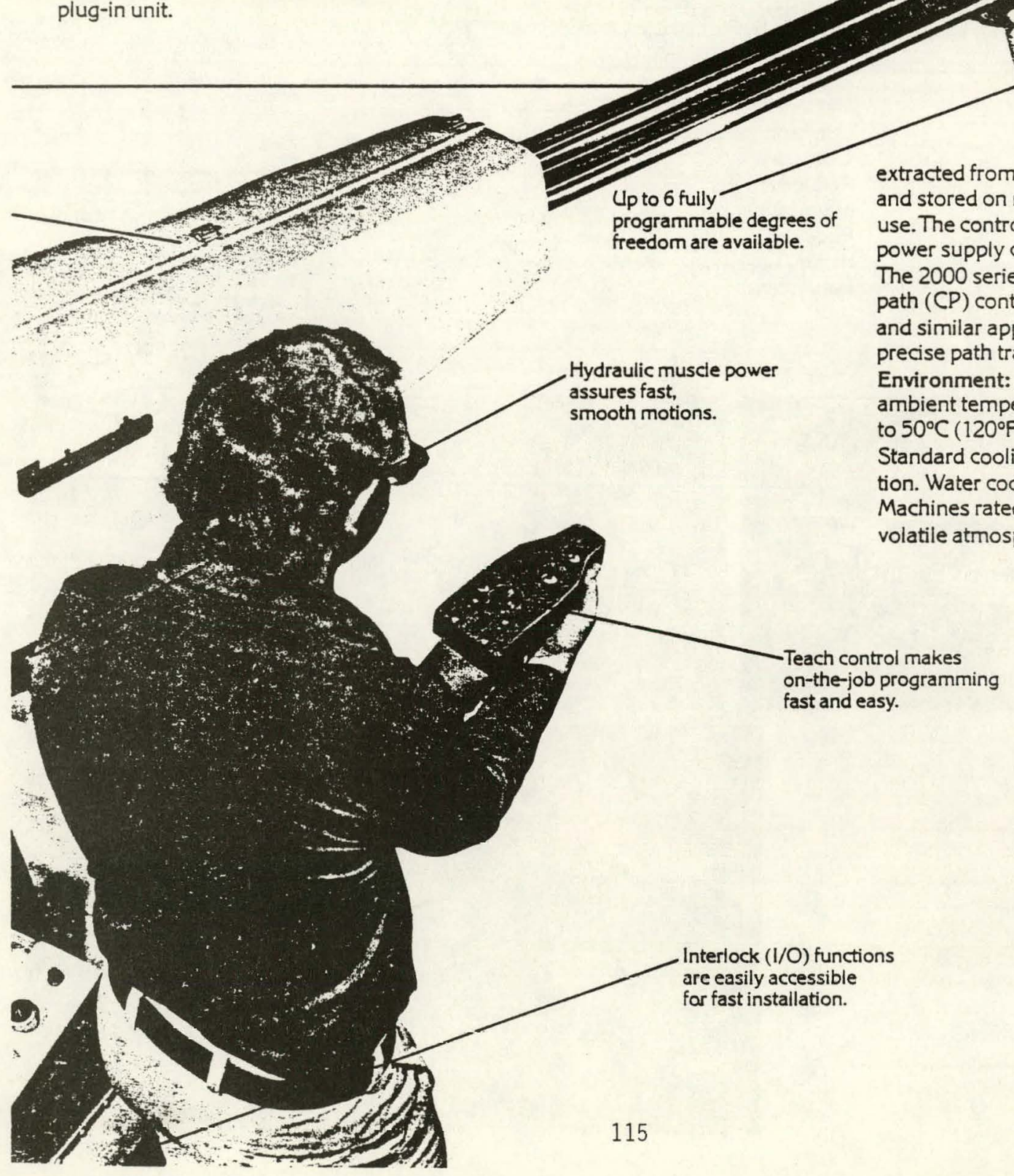




\section{Leadership through experience}

Unimate performance has been proven through millions of hours of experience, worldwide, in metal working, material handling, casting and forging, glass manufacturing, automotive assembly in tasks that are monotonous, tiring, disagreeable, dangerous and debilitating to humans.

\section{Check these Unimate benefits} lici eased productivity -from $25 \%$ to $40 \%$ and more as reported by Detroit Diesel, Fiat, Doehler-Jarvis.

Increased product quality and fewer rejects - says Chrysler, Inland Die Casting Corp., Evinrude-in sonte cases by a factor of $70 \%$.
Improved capital equipment utilization-Unimate "up-time" of better than $98 \%$ assures high equipment utilization says Volvo, Ford, Bauer Products, Alfa Romeo, Briggs \& Stratton. Inflation resistant - the Unimate you hire today will be working at the same hourly rate 5 years from now says Cast Specialties, Advance Pressure Castings, Texas Instruments. Fast, easy installation - fast response time means accrued benefits sooner says Chrysler, Lunkenheimer, Twin City Die Casting.

Round-the-clock output - no second or third shift production slow down reported by Pemco Die Cast Corp., Ford, Tube Turns.

Flexibility-permits use in custom shop and batch processing environments says Dittmann Neuhauss, Doehler Jarvis,

Evinrude.

Reduced in-process inventory and material handling - as experienced at Rockwell International, Texas Instruments, Tube Turns; International Harvester.
Improves competitiveness - says

Lunkenheimer, Chevrolet, Superior Die Casting.

Reduces indirect and hidden costs - less die maintenance, reduced energy consumption, less lost production due to illness and absenteeism, lower costs for OSHA compliance reported by Chevrolet Superior Die Casting, Fiat, Del Mar Die Casting, A. O. Smith
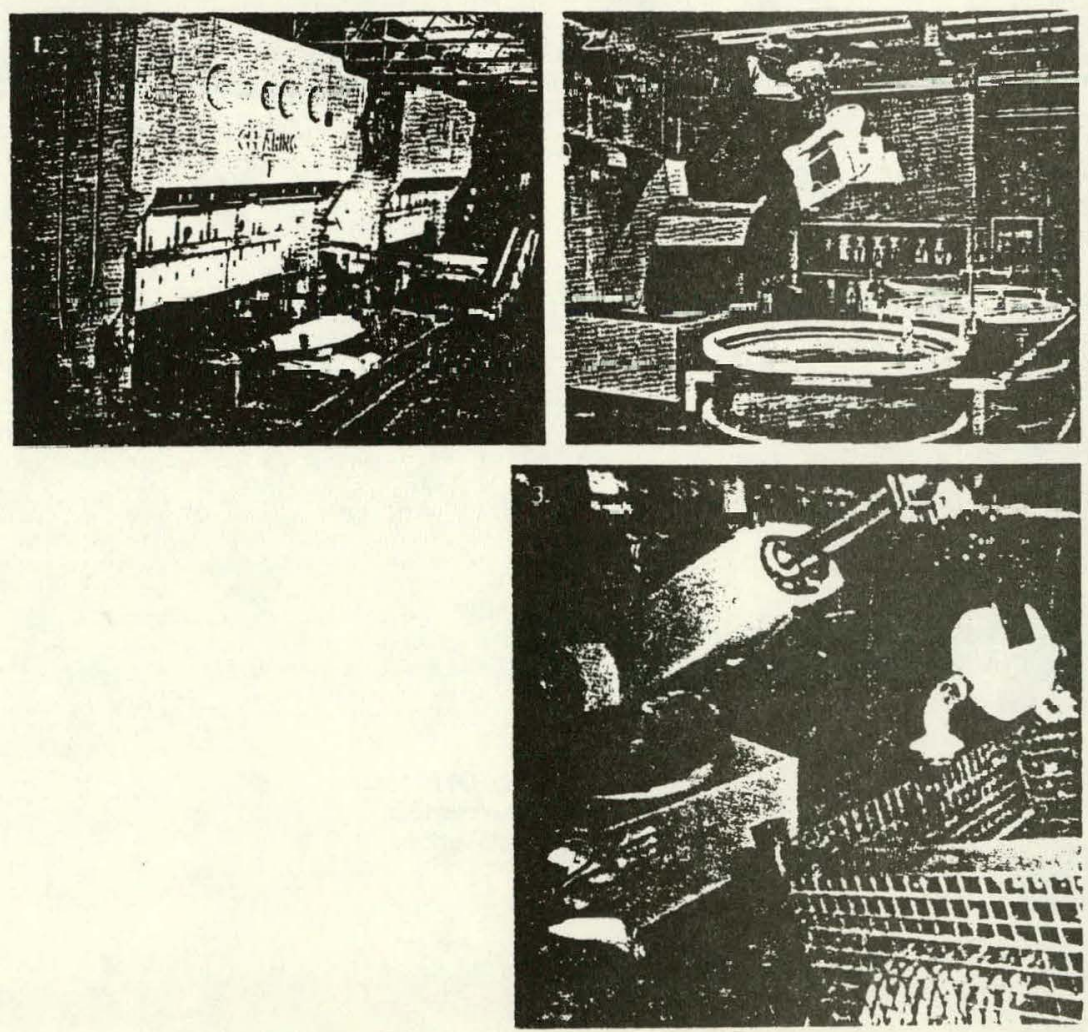
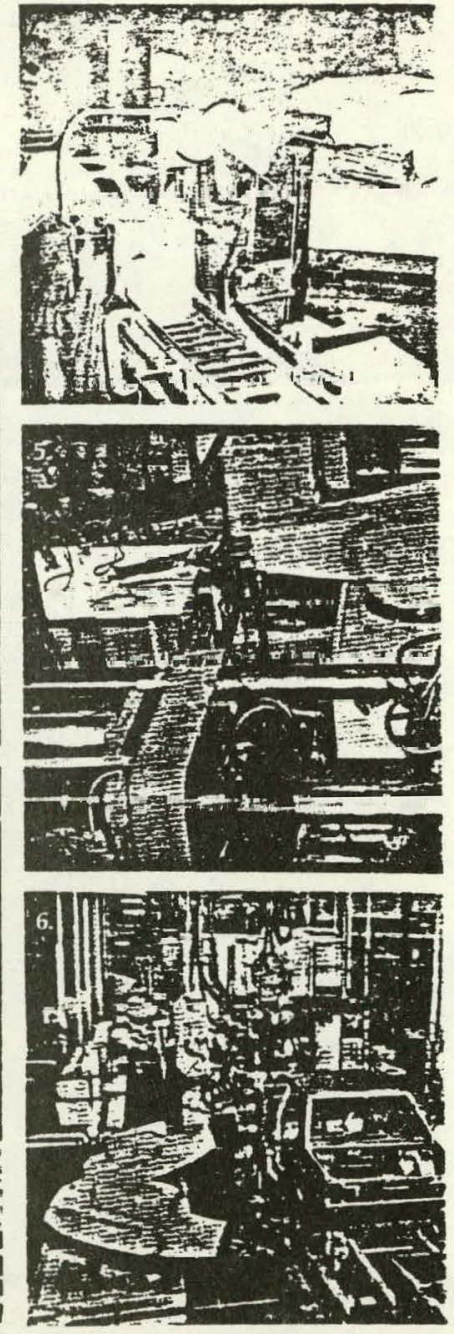
These are but a few of the benefits that Unimate industrial robot users have reported. They are some of the reasons why our customers continue to add Unimates to their work forces. Consider the applications depicted on these pages. The answers to your automation needs may well be illustrated.

Our extensive library of application and technical bulletins and movie films is at your disposal. Our experience will serve you well.
1. Punch and stamping press transfer A Unimate robot is a real OSHA problemsolver when operating with punch and stamping presses. A battery of Unimate robots in a press transfer line guarantees consistent throughput, shift after shift. Change over in batch run processing can be done in minutes by using Unimation's Cassette Program Storage Unit which preserves (Inimate programs on magnetic tape.

\section{Investment casting}

Scrap rates as high as $85 \%$ have been reduced to under $5 \%$ when Unimates are used in this highly sophisticated process. The robot's dexterity and repeatability assure consistent mold quality never before achieved in the dipping process.

Unimate robots are being used singly or in totally automated DNC systems in which dozens of different wax molds, weighing from a few pounds to over $300 \mathrm{lbs}$. are processed by as many as 10 robots.

\section{Materials handling}

From raw material in the back door to finished goods out the front door, materiais handling is a necessary evil that costs money and is often labor intense. The Unimate robot becomes a real probiem soiver because it has the muscle. dexterity and versatile memory to pack or transfer goods in complex palletized arrays without product damage or lost counts. And it's cheaper than special-purpose equipment that is quickly made obsolete by product change.

4. Forging

One of the toughest industrial jobs is forging. Unimate robots operate forge hammers, presses. upsetters and trim presses without fatigue or the need for relief operators. In some cases a Unimate will do the work of six men per shift, yielding a handsome payout.

\section{Die casting}

Because productivity gains with Unimate robots are so dramatic, it is often unnecessary to invest in additional die cast machines. Scrap rate reductions of as much as $70 \%$ are common. The Unimate can unload the die cast machine, quench the part, feed a trim press, load inserts, service two die cast machines, ladle aluminum and perform die care. The robots' flexibility and consistency are cost-cutting benefits that guarantee high return on investment for both custom and captive shops.

\section{Automotive assembiy}

Unimation Inc's family of robots spot-weids automobile and truck assemblies for almost every major manufacturer throughout the world. Applications include construction of subassemblies, body sides, underbodies and front structures, as well as body framing and respot. Consistency of spot location and weid integrity yield automotive assemblies of the highest quaiity. The Unimate robot's versatile memory easily accommodates any product mix. And, with the aid of Unimation's Program Editor, program adjustment to accommodate variations such as metal fit ups are easily made without interrupting the production cycle.

\section{Machine tool loading}

Twn-fisted Unimate robots hoid the key to machine tool productivity. Rapid loading and unloading of work pieces assures high utilization of costly capital equipment. Using Unimate robots to simultaneousiv serve several machine tools reduces in-process inventory and costly material handling, and has reduced piece part costs by as much as $65 \%$. A Unimate machining system is the ultimate in automated parts manufacturing.

\section{Continuous path applications}

Velocity and path control add to the versatility of the Unimate 2000 series. Capable of being operated in either point-to-point (PTP) or continuous patn (CP) modes, this nurlet is ideally suited to arc (gas) weiding, routing, sealant application, moid spraying and bake out. degating. pad machining and grinding, flame cutting and other process tasks requiring smooth, accurate. three-dimensional paths and velocity control. In either mode, Unimation's point-to-point. lead-it-by-the-hand teaching method is relained. 


\section{Leadership in customer sorvices:}

From grippers to testers, seminars to service training, spare parts to systems, your needs are met by Unimation's experienced staff of sales, applications and service engineers, training instructors and service order dispatchers. The many services and accessories offered by Unimation Inc. are designed to give you full support and to assure you of a itigh return on your investment in Unimate robots.

\section{Hand designs}

The hands that can be used on the Unimate fall into three general categories: mechanical grippers, surface-lift devices and tools.

Mechanical grippers employ movable, finger-like levers, paired to work in opposition to each other. A single hand might have one or several sets of opposed fingers. Likewise, a robot might have more than one hand.

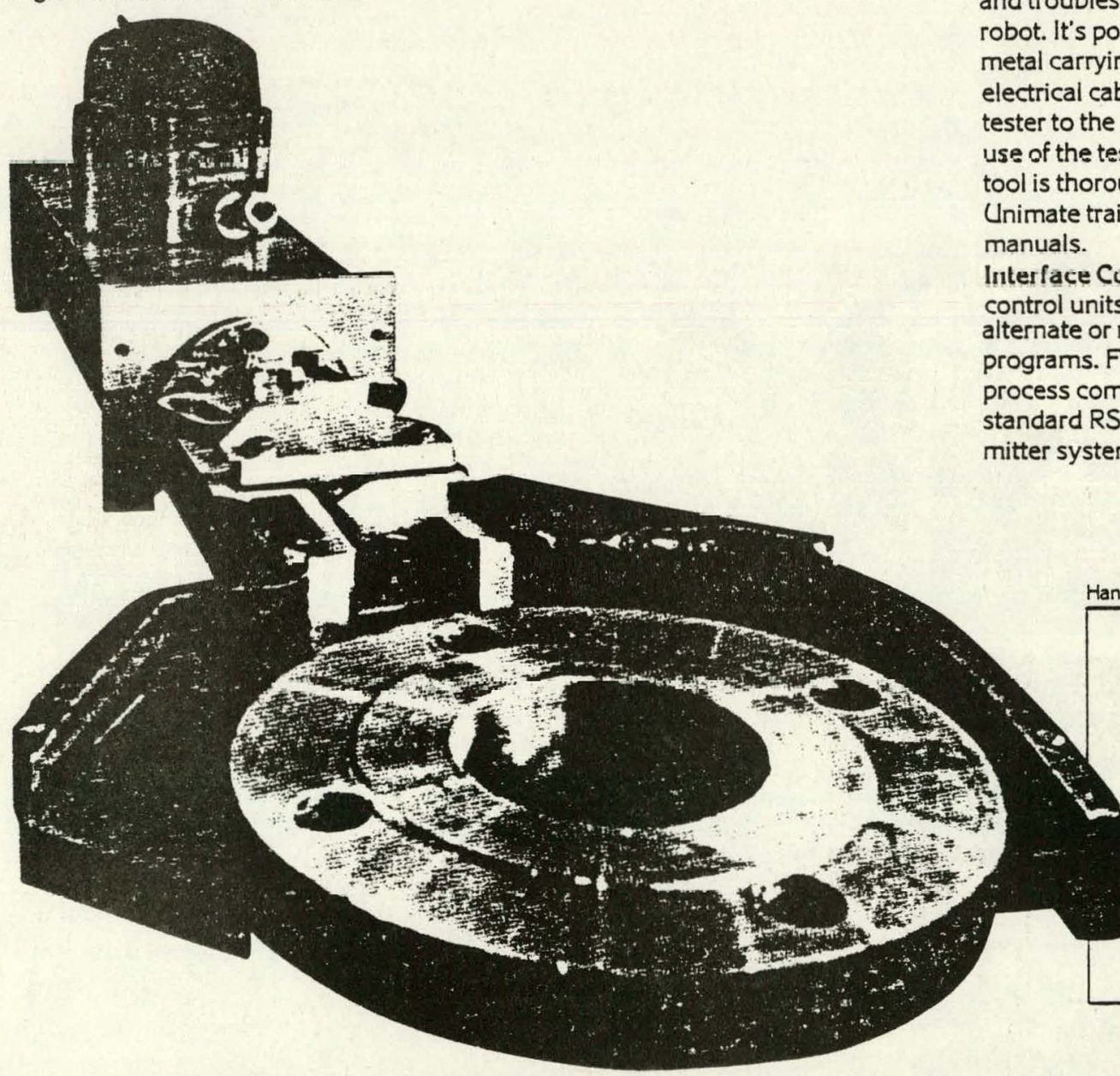

Surface-lift devices are exemplified by vacuum pick-ups and electromagnets for handling durable, delicate (glass) or ferrous materials with flat or curved surfaces. Tools that serve as robot hands include spot welding guns, impact wrenches, spray heads or arc welding torches.

Unimation engineers have accumulated a substantial library of hand-tooling designs based on these three general categories. With this kind of experience, our enginecrs have the know - how and ingenuity to design, build and test robot hands to meet any special requirements your application demands. 


\section{Services}

Robot Seminars. Unimation Inc. conducts periodic seminars on robotics tailored to specific application areas such as machine tool loading, punch and stamping press operations, resistance and arc weiding, and die casting. These are hard-hitting, shirtsleeve sessions that give you the practical information you need to evaluate the use of Unimates in your operation. At your request also, we will develop a custom seminar to fit your specific company needs.
Customer Training Program. Our customer training program is designed just for you. We teach your personnel how to operate, maintain and repair the equipment, at our facility or in your plant. With qualified in-house capability, you can assure yourself of high and uninterrupted Unimate performance.

Customer Service Program. Our staff of field service engineers is available to assist you with your installation, service needs and spare parts requirements.

\section{Systems}

Unimation engineers have gained extensive experience in virtually every field of manufacturing. The result is a capability to design and build systèms around the robot which offers you the most efficient, flexible means available to cut costs and improve productivity. A system can be as simple as one robot and some workpiece orienting devices, or a multiplicity of robots integrated into a totally computerized manufacturing process.
Systems supplied by Unimation range from brick handling equipment including palletizing conveyors, kiln car indexer, process controller and robot to automotive assembly lines with 15 to 30 robots, car body shuttle conveyor, supervisory control and spot weld guns. Machining systems for processing parts from raw castings to finished goods have been developed using conventional or $\mathrm{NC}$ machine toois and employing the principles of group technology.

These systems provide the ultimate in flexibility, insure quality of product, can be on stream fast, and result in impressive productivity gains.

Our applications engineers stand ready to help your staff upgrade your manufacturing process. Give us a call. We welcome the opportunity to work with you.
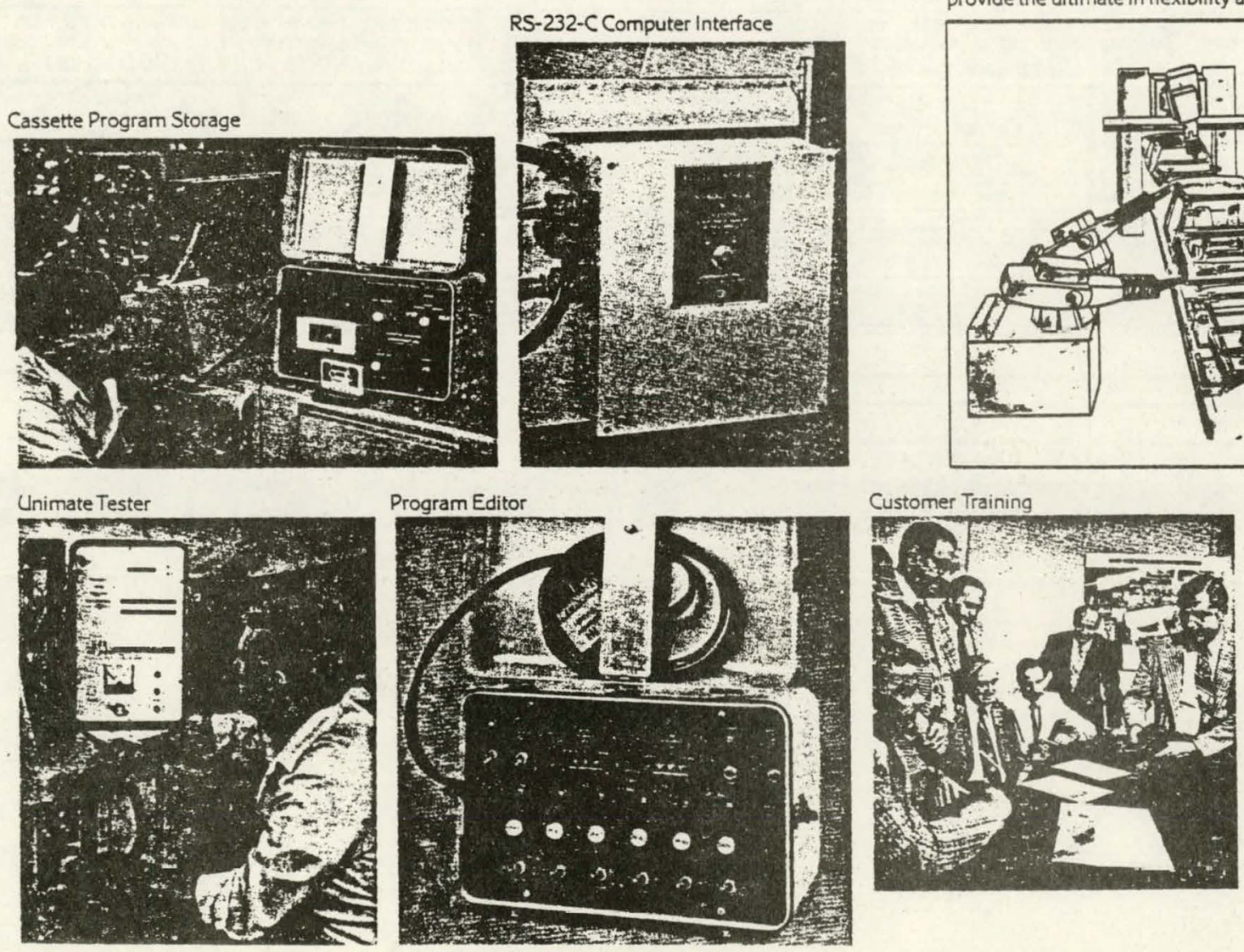


\section{Leadership in product flexibility}

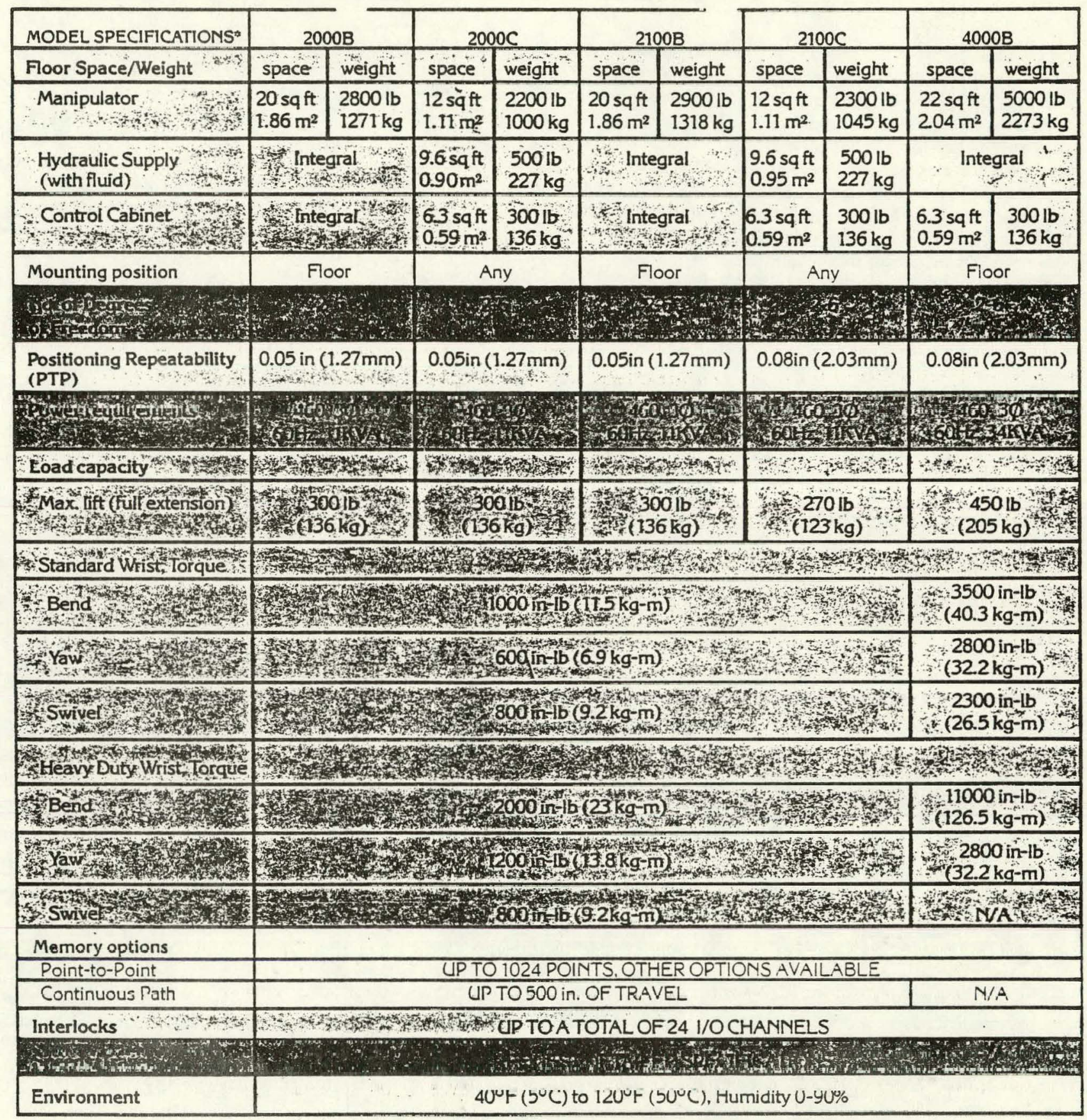

For more detailed installation and performance data and available options.

contact Unimation Inc. Unimation Inc. reserves the right to make changes

in equipment specifications at any time without notice.

\section{Unimation Inc.}

A subsidiary of Corporation

Headquarters:

Shelter Rock Lane

Danbury, Connecticut 06810
Midwest Regional Office:

32500 W. Eight Mile Road

Farmington, Michigan 48024 


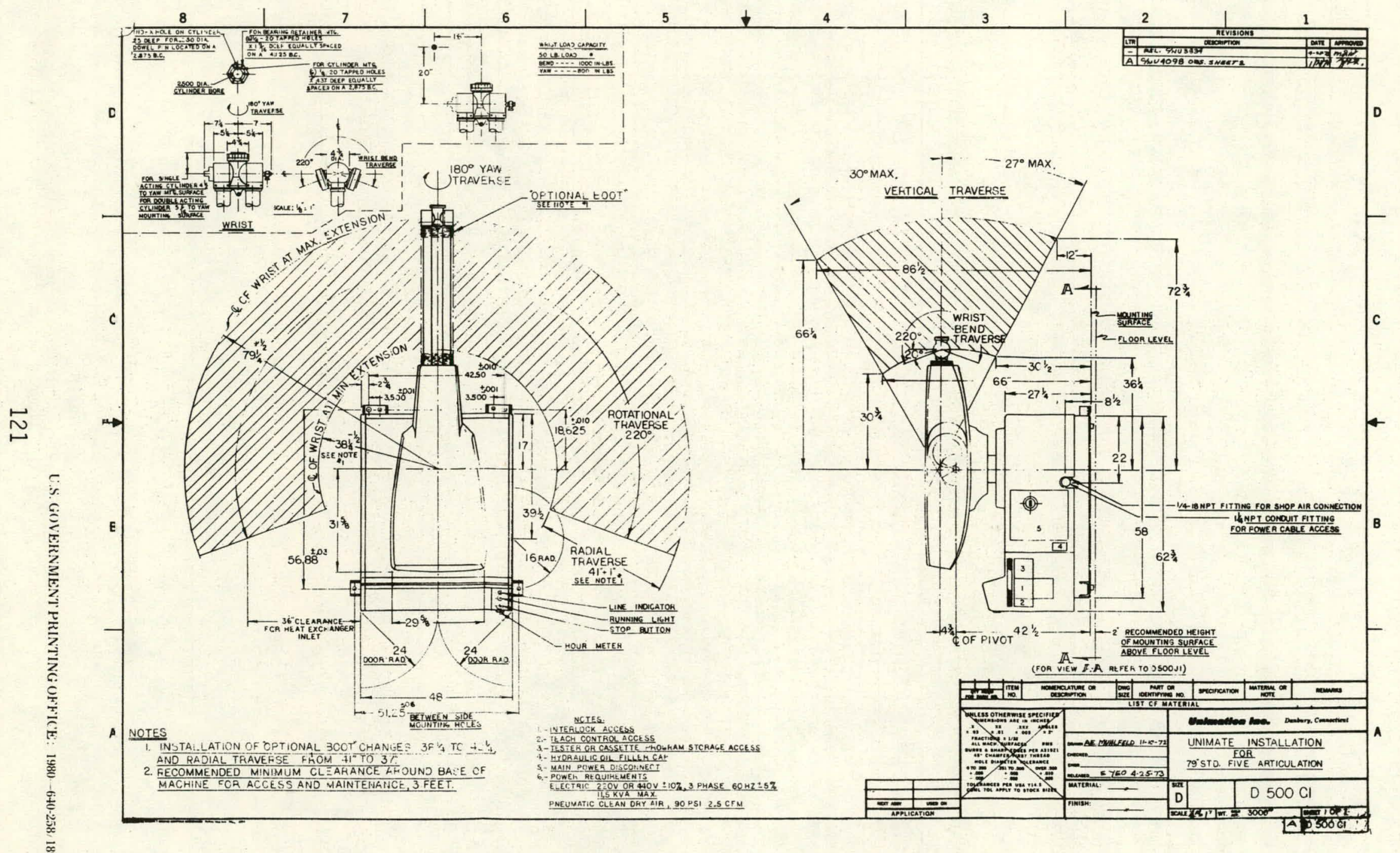

